Portland State University

PDXScholar

8-19-2020

\title{
Catholic Social Teaching and Sustainable Development: What the Church Provides for Specialists
}

Anthony Philip Stine

Portland State University

Follow this and additional works at: https://pdxscholar.library.pdx.edu/open_access_etds

Part of the Ethics in Religion Commons, Political Science Commons, and the Public Affairs Commons Let us know how access to this document benefits you.

\section{Recommended Citation}

Stine, Anthony Philip, "Catholic Social Teaching and Sustainable Development: What the Church Provides for Specialists" (2020). Dissertations and Theses. Paper 5604.

https://doi.org/10.15760/etd.7476

This Dissertation is brought to you for free and open access. It has been accepted for inclusion in Dissertations and Theses by an authorized administrator of PDXScholar. Please contact us if we can make this document more accessible: pdxscholar@pdx.edu. 
Catholic Social Teaching and Sustainable Development:

What the Church Provides for Specialists

by

Anthony Philip Stine

A dissertation submitted in partial fulfillment of the requirements for the degree of

\author{
Doctor of Philosophy \\ in \\ Public Affairs and Policy
}

Dissertation Committee:

Christopher Shortell, Chair

Kent Robinson

Jennifer Allen

Daniel Jaffee

Portland State University

2020 
C 2020 Anthony Philip Stine 


\begin{abstract}
The principles of Catholic Social Teaching as represented by the writings of 150 years of popes as well as the theorists inspired by those writings are examined, as well as the two principal schools of thought in the sustainability literature as represented by what is classically called the anthropocentric or managerial approach to sustainability as well as the biocentric school of thought.

This study extends previous research by analyzing what the Catholic Church has said over the course of centuries on issues related to society, economics, and the environment, as embodied in the core concepts of subsidiarity, solidarity, stewardship, the common good, and integral human development. This body of work and the core principles therein present a set of standards and guidance that will enable the work of nongovernmental organizations, state actors, and individual activists to achieve the commonly accepted goals of sustainable development in a manner that respects the autonomy of persons and families as well as respect for cultures and communities of historically poor and oppressed peoples in the developing world, as well as in the wealthy nations that drive much of the development agenda.
\end{abstract}




\section{Dedication}

The To my amazing wife Krystle

and

To my family who supported my education 


\section{Acknowledgements}

I wish to express my sincere appreciation to my advisor, Professor Christopher Shortell, who has a remarkable amount of patience: he calmly guided and pushed me in this process to not only finish this document but to provide a document that was better than I could have written on my own. Without his persistent help, the final product would never have been realized. 


\section{Table of Contents}

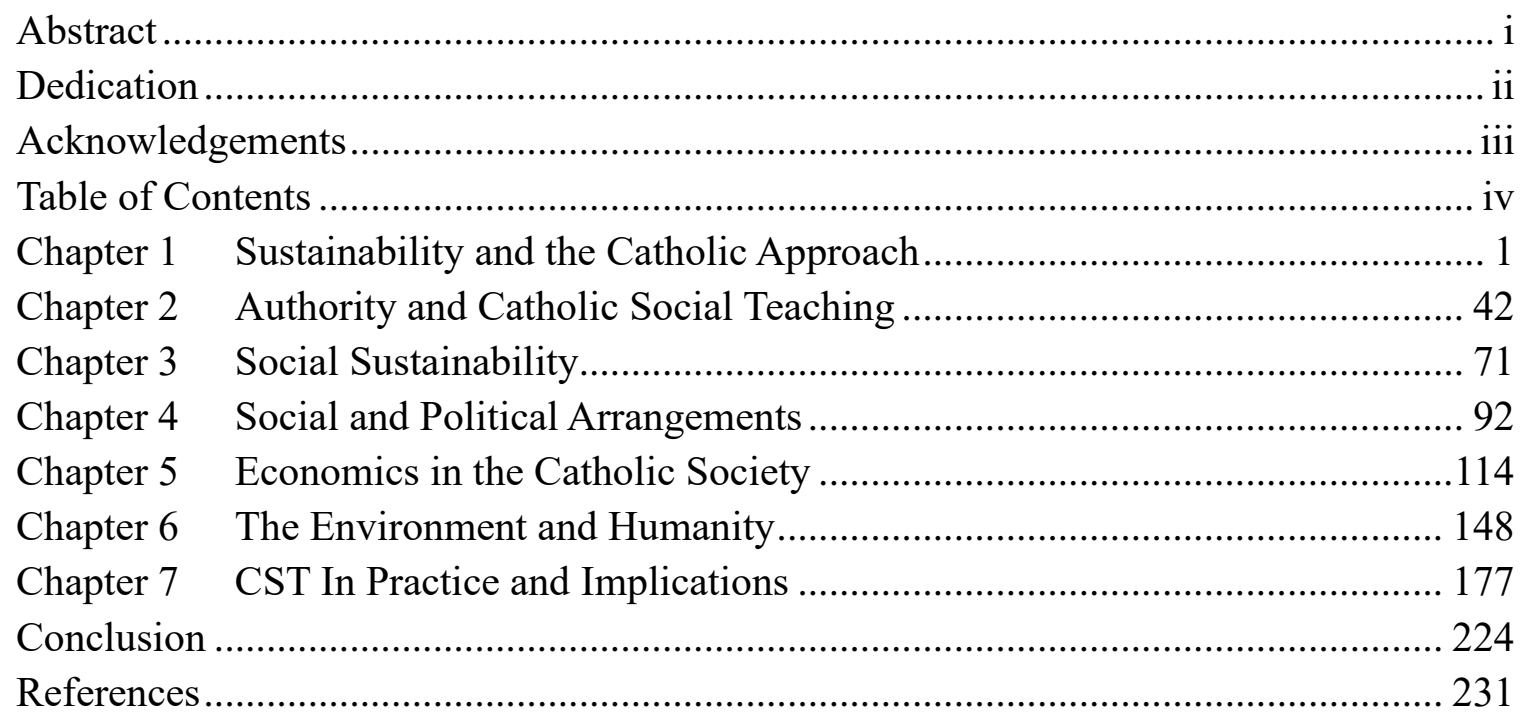




\section{Chapter 1 Sustainability and the Catholic Approach}

Sustainable development is a preeminent issue in the world of public policy. The issue is steeped in much history. At present, the debate intersects issues of social justice, environmental degradation, the sovereignty and autonomy of indigenous peoples, global governance, and numerous issues related to economics and democracy. These issues are built upon debates about the nature of the human person and the collective and individual relationship human beings have with the natural environment. The debates in the literature focused initially on what is often called the developed world presently, but over time grew to include the concerns and needs of the developing world. ${ }^{1}$ This reflected the underlying assumptions of those who initially developed the concepts and later those who saw value in the concept of sustainable development but sought to have the issues not included in this debate given the attention that was deserved.

As a concept, sustainable development seeks to address a problem. While the problem associated with sustainable development is environmental degradation, the environment is only one important facet of the problem. Sustainable development seeks to address structures and relationships that lead to environment harm, including human relationships, economic systems, geopolitical relationships, and an international

\footnotetext{
${ }^{1}$ While recognizing the complexity and value-laden nature of the various terms used in the various development-related fields, I will be using the terms "developing world" and "developed world" predominantly throughout this dissertation, in part due to this being a work of political and administrative theory, and also in part in recognition of the dignity of the peoples of the developing world and the complex relationship that the developed world has with them.
} 
environment that is characterized by competition instead of cooperation between peoples and states. These issues are interconnected and require a holistic approach (Flint 2013). Sustainable development is an issue concerned centrally with social justice (Vincent 2009; Dobbs 1999). Until recently, the discussion for sustainable development excluded the countries of the developing world, with many of these countries struggling for influence (Fischer and Green 2004).

The work of sustainable development is presently being done by a wide range of actors. Governments, non-governmental organizations (NGOs), individual activists, academics, members of the business community, and others from every conceivable realm are engaged in this work. These efforts are multi-stakeholder, and the complex nature of these relationships makes implementation of programs difficult, with policy successes both not as common as the supporters of sustainable development claim but also not as rare as the detractors either (Beishem and Simon 2015). There are numerous reasons for this, but at the most basic level, the issue of wicked problems is at the center. A wicked problem is defined by Rittel and Webber (1973) as those incomprehensibly complex and messy issues that are difficult to define, let alone to solve due to the complex intersectional nature of the problem with other social issues. For the purposes of this dissertation, I use the definition of sustainable development that comes from The World Commission On Environmental Development (WCED) report Our Common Future (aka, the Brundtland Commission Report), which defined sustainable development as "development that meets the needs of the present without compromising the ability of future generations to meet their own needs," (Brundtland 1987, 43). According to the report, this definition contains within it 
two key concepts: the concept of "needs," in particular the essential needs of the world's poor to which overriding priority should be given, and the idea of limitations imposed by the state of technology and social organization on the environment's ability to meet present and future needs (Brundtland 1987, 43). The Commission recognized that sustainable development requires the promotion of values that develop standards for consumption that all human beings can reasonably aspire to that are within the bounds of the ecological limits of consumption (Brundtland 1987). Built into the definition put forth by the Commission in Our Common Future is a recognition of what the Catholic Church calls the dignity of the human person, as recognized in the requirement that consumption levels be available to all human beings. Human dignity is essential to this dissertation and is given focus in Chapters 3 and 4.

The prevailing attitude among some researchers and policy planners had been until recently that Christianity was in large part responsible for the environmental crisis. The most influential theorist was Lynn White, who in 1967 published the deeply influential article "The Roots Of Our Ecological Crisis," which argued that the norms of the Christian West in the Middle Ages were largely the source of scientific attitudes that have led to the present ecological crisis (White 1967). This was due to technological and cultural developments in Europe in the early middle ages that led to the changing of the relationship between humans and the environment from one of embedded harmony to exploitation. Central to White's thesis is the claim that the environmental crisis stems from a JudeoChristian teleology, with subtle emphases on men dominating women. According to White, men were put in charge of creation, for it was all for the benefit of male humans. Humans 
are made in God's image and Creation was made for humanity. Exploitation of nature is rooted in Christian cultural values which remain despite the increasing secularization of the western world (White 1967). White expresses his thesis succinctly when he stated that Christianity of all religions is responsible for the anthropocentric roots of the environmental crisis: "Especially in its Western form, Christianity is the most anthropocentric religion the world has seen.....man shares, in great measure, God's transcendence of nature. Christianity, in absolute contrast to ancient paganism and Asia's religions, not only stablished a dualism of man and nature but also insisted that it is God's will that man exploit nature for his proper ends" $(1967,1205)$. Anthropocentrism is the assumption "that human reason and sentience places the human being on a higher ground," (Seckinelgin 2006 31). Deep ecology is rooted in the work of Arne Naess, who viewed the prevailing anthropocentric environmental movement as shallow and developed an alternative approach that was spiritual in nature, seeking significance in a harmonious union with nature. This approach draws on the cultures of indigenous North Americans, Asians, and African cultures as examples of a more fruitful and sustainable future (Taylor 2001).

White is correct in one part of his assessment: that humans are willed to "exploit nature for his proper ends," though exploitation is a provocative term that is loaded heavily with assumptions that White and contemporary Christian environmental scholars would debate. The disagreement is what proper ends entails and to what purpose. I emphasize the deicentric nature of this relationship, that is, that a Catholic view of sustainability and human relations is one that is meant to be centered on or built around the relationship the 
person and community has with God. The purpose of this dissertation is twofold: primarily, to present Catholic Social Teaching as providing insight and wisdom for the development community to better facilitate development in the heavily Catholic developing world. Second, and because of the first purpose, to present an alternative to White's thesis. I present Catholic Social Teaching as a contribution to the sustainable development literature that will provide concepts, and insight into the values taught by the Catholic Church in the context of economics, social organization, and the relationship humans have with the environment. Catholicism is a growing faith in the developing world (Inglehart, et al 2014). My great hope is that this dissertation will help bridge the divide between the anthropocentric and the biocentric schools of thought through the presentation of Catholic Social Teaching as a deicentric understanding of the relationship between humanity and the environment, rooted in the relationship between human beings and God.

This is rooted in the contribution of Pope Francis to the environmental and sustainable development debate that began with his encyclical Laudato Si (2015). While not the first time a pope or influential layperson has spoken on environmental issues, the influence of Laudato Si has made the Catholic Church an influential voice in the discussions surrounding sustainable development (McCallum 2019; Lahsen and Dominques 2015). In 2019 the Vatican hosted the Pan-Amazon Synod, which featured representatives of indigenous peoples from the Amazon region of South America, as well as church officials and representatives of various development organizations, including the United Nations. This synod resulted in the 2020 papal encyclical Querida Amazonia, which is a continuation of Laudato $S i$ with a focus on the conditions of the indigenous peoples of 
the Amazon. This Synod and the participation of peoples from a wide variety of backgrounds and vocations speaks to the influence of the Church on these issues (Luciani and Berzosa 2020).

Ladauto Si is Pope Francis' first addition to Catholic Social Teaching. The papal encyclical (or papal letter) made a strong impression in the media and among political leaders when it was released in 2015. This is a first for social teaching documents of the Church that are focused on economics and social justice. Catholic Social Teaching is defined by the Vatican as "transforming social realities with the power of the Gospel," (Catholic Church 2004). Esolen describes Catholic Social Teaching as "the fleshing out, in pragmatic and general terms, of the twin commandments of Christ: 'You shall love the Lord your God with all your heart and soul and mind and strength, and you shall love your neighbor as yourself," (2015, para. 1). Catholic Social Teaching (CST) is not a set of policy prescription and does not require particular forms of government. CST requires a society built upon more than mere materialism, regardless of the ideology accompanying that materialist outlook. CST defends private property, defends the family unit, and the right to form free associations for social and political purposes to secure the common good (Esolen 2015). The implications of CST are the subject of this dissertation, with the purpose of exploring how CST has been implemented in various places around the world and the implications for development in the developing world.

Catholic Social teaching is built upon the core concepts of Subsidiarity, Solidary, the Common Good, Stewardship, and Integral Ecology. At the core of CST is a vision of a 
decentralized polity and international community that places the most important decisionmaking authority at the most local level possible (Esolen 2012). On the one hand, these principles of Catholic Social Teaching complement much of the existing sustainable development literature because of the recognition for the need for both social justice and a view of the human person that is embedded in nature (Hiwaki 2017; Brown 2005; Cooper and Vargas 2005). On the other hand, the conflict comes in the form of these values and the greater call by the United Nations and major powers of the developed world for internationalization of environmental issues and policy design, as well as in obvious conflict with population control policies presently being promoted by some NGOs such as the Gates Foundation (Schulz and Bendix 2015). This is not as simple an issue to understand as the Church always proposing localism and the UN always proposing internationalism and centralization, either, as the recent Pan-Amazon Synod in the Vatican attests (Francis 2020). Subsidiarity requires that the most local unit of government possible be the locus of control and implementation for what policy specialists would call policy decisions. Subsidiarity recognizes responsibility of political leaders that does not supersede the authority or autonomy of the local actors. Subsidiarity is defined by Ahlquist as "what the higher orders owe the lower orders without superseding the authority of the lower orders," (Ahlquist 2012, 79). The development literature makes clear that the values of subsidiarity and the international sustainable development goals are often in conflict. Catholic Social Teaching offers a fruitful course that can help chart a path that respects local authority and decision making while also respecting international institutions and working in concert with other local authorities or the international community when the 
need arises. Often there is a tradeoff between subsidiarity and the common good for achieving the goal of a socially just world in balance with the environment, requiring cooperation with or even at times surrendering authority to the meso-level of policy implementation when needed. This can be the case when addressing wicked problems that cross jurisdictional boundaries or are beyond the scope and scale of local associations to address in isolation. Subsidiarity is applicable to all levels, and it must be recognized that optimizing local decision-making authority in cases of overlapping jurisdictional interest may cause chaos and harm in other jurisdictions. CST is sensitive to this question and recognizes that tradeoffs are at time necessary, with the example being Pope Francis' work with the United Nations and the European Union on economic and migration issues.

Subsidiarity is not always an absolute right to local control in a world of complexity and wicked problems. The nature of overlapping jurisdictions in natural resource management is one example of this that is relevant to the discussion of sustainable development and is explored in greater detail later. Pope Francis expands and clarifies the concept of subsidiarity in Catholic Social Teaching in recognition of the complexities of the modern world through the concept of what can be termed a positive subsidiarity, where higher levels of authority should respond to social ills and resource problems as needed, while continuing to respect the autonomy of life of those at the lower levels of the governance hierarchy (Francis 2015). This is like and compatible with the concept of nested authority, which Ostrom (1990) describes as a series of overlapping jurisdictions that must respect one another while sharing in the governance of Common Pool Resources (CPRs). Clearly, Laudato Si re-presents subsidiarity as a concept that is still of incredible 
importance in CST but is not the overriding rule for policy development and implementation.

The principles of CST can come into conflict in the real world of policy design and implementation. Subsidiarity, solidarity, stewardship, The Common Good, all are part of a larger, integral whole. Subsidiarity is often emphasized above the other principles, and often subsidiarity in the strictest sense can have primacy of place in application. But when these values come into conflict due to complexity in any policy area that can be covered by sustainable development, the real central value is the promotion of the Common Good. All other values are meant to reinforce and protect the Common Good and the pursuit of a society that defends it. The principle task of the state is the promotion of the Common Good (Argandoña 2013; Maritain 1951). Subsidiarity is one principle that assists in achieving that goal, but when conflict arises subsidiarity can come to mean different things. Competency is important to remember, as subsidiarity's guiding values are both respect for the people at the most local level of governance and competency to address problems. In a situation of international food shortages due to climate change, the situation changes. Pursuit of the Common Good requires that the state or even supranational organizations address problems while still respecting the needs of the local people. Subsidiarity may be seen have primacy in Catholic Social Teaching but in reality it is more accurate to describe subsidiarity as being a first among equals in the principles of Catholic Social Teaching, with the Common Good being the end goal of subsidiarity, solidarity, and stewardship.

The Catholic view of the development issue as expressed by the Social Teaching 
tradition is important for several reasons. First, the growth of Catholicism in the developing world, where Catholicism has a strong influence in secular life makes this especially important (Inglehart, et al. 2014). Secondly, the intellectual tradition of the Church in the areas of economics, social justice, and in recent decades, environmental thought, align well with the issues facing policy makers. The purpose of this project is to present the teachings of the Catholic Church as they relate to this problem of sustainable development and demonstrate that CST has valuable contributions to make towards achieving development goals. Catholic Social Teaching is framed in the traditional three legs of sustainable development: the social, economic, and environmental realms of analysis. This framing of sustainability in these three pillars have been sourced in the literature to the Brundtland Report, Agenda 21, and the 2002 World Summit on Sustainable Development (Purvis, Mao, and Robinson 2019; Moldan, Janoušková, and Hák 2012).

While Catholic thought traditionally is understood as theological to the outsider, it is the social teachings of the Church that will be the principal focus of this exercise. This is not to say that this dissertation will focus exclusively on the pillar of environmental sustainability. The focus is on an integrative approach to Catholic Social Teaching and the issue of sustainable development broadly. In addition, the problems related to sustainability will not be the initial focus. Of immediate concern will be the need to present a relatively concise presentation of what the established views of sustainability are, with focuses on the deep ecology, anthropocentric, and the newly emergent green conservatism. From there I will divide the study into the three core areas of sustainability (economic, environmental, and social), to frame the discussion on what the Church teaches. Why this approach? Once 
it is understood by what is meant as 'environmentalism' and 'sustainability' we can then better understand what the Church teaches in order to better understand areas of potential mutual understanding and conflict. This is especially important when we understand that these are concepts that are broadly misunderstood even by Catholics while Catholics often share some of the very same concerns that sustainable development policymakers and developers have. The values taught by the Catholic Church for the public sphere are essential for these public servants to understand in order to design policies that do not conflict with these values that will accomplish sustainable development goals that are critical at this time.

The Catholic view is also important for institutional reasons unique to the Catholic Church. Like any organization, the Catholic Church is subject to the rules of bounded rationality. Simon (1957) describes bounded rationality as a search process guided by aspiration levels or goals. An aspiration level is a value of a goal variable which must be reached or surpassed by a satisfactory decision alternative. In organizational theory goal variables can be thought of like profit and market share. In Catholic Social Teaching, this can be understood in terms of human dignity and the Common Good. Satisficing describes the process of finding the option out of the decision alternatives that achieves or surpasses the aspirational goals of the organization. These aspirational goals are demonstrable in sociological theories of organizations that treat leadership and organizational design as rational, conscious, planned actions, such as Selznick (1957). In Selznick's framing, the policy environment is an important constraint or, conversely, moment of opportunity for the organization and its leader to motivate change. This is impacted by the resources that 
the organization can muster in pursuit of policy goals. Given that top managers have a clear image of their organization's character centralization of authority allows them to preserve it (Selznick 1957). The change in direction seen in the Catholic Church today by Pope Francis may be extremely difficult to change in the future, due to the tendency of organizational actors and especially those in leadership positions making rational decisions that lead to the construction of institutions and reforms around themselves that constrains their ability to change further in later years. Often these reforms lead to adoption and implementation of programs that are not intended by the authors (DiMaggio and Powell 1983). The Church adopting a more green-focused CST is an example of organizational learning, due to the Church adapting to a changing social environment (Levitt and March 1988; DiMaggio and Powell 1983). An example of CST being adopted in ways not intended by the Popes is the development of some forms of Catholic socialism or fascism despite both ideologies being condemned by Popes Pius XI and XII (Pius XI 1931; Pius XII 1949). There are few organizations in the world today as top-down oriented as the Catholic Church, and the vision of Pope Francis and his implementation of CST in the aftermath of the release of Laudato Si clearly demonstrates Selznick's historic theories of organizational leadership in real time (Monaci 2020).

Moving forward, in this chapter I address what sustainable development is and its roots, as well as a more detailed explanation of why the Catholic view of sustainable development matters. This chapter concludes on an examination of the nature of the sustainable development debate and a literature review of the non-Catholic sustainability literature. Chapter 2 is dedicated to the authority the Catholic Church has to offer teachings 
on economics, social and political organizing, and the environment. Chapter 3 is dedicated to the Church's view of the human person and family. Chapter 4 builds on Chapter 3 and presents CST and social and political arrangements. Chapter 5 is dedicated to Catholic economics, and Chapter 6 is focused on CST and human relationship with the environment. Chapter 7 presents the implications of Catholic Social Teaching and examples of CST in practice in the real world.

As a disclosure, I feel it pertinent to declare that I am myself a practicing traditional Catholic. My goal is to present the teachings of the Church as objectively as possible so that policy prescriptions for a wide variety of issues can be understood. The framing of Catholic Social Teaching into the three areas of sustainable development will assist in this. The Catholic Church has in its rich history of social teaching a body of work that addresses numerous society-changing issues as they have arisen throughout history: this includes what Gregory XVI to John Paul II have labeled dangerous ideologies like communism, socialism, liberalism, and German fascism, as well as economic theory, just war, nationalism, and human rights. The purpose of this body of work is aimed at assisting leaders find solutions that promote the common good, defends the family, and protects human dignity. My religious beliefs certainly played an important role in deciding on this topic but understanding what the Church teaches related to sustainability is important to anyone interested in sustainability. The growth of the Church in the developing world as well as the growth of Catholicism in some parts of the US among younger populations demonstrates that the worldview of the Church should be understood due to the implications the formal teachings of the Church have on the discourse and direction of 
sustainability-related policy.

\section{Sustainable Development}

While sustainable development is of concern to any country of any standing in the world today, it is most closely associated with the work of non-profit organizations and businesses adapting to the post-Rio world when working in the developing world, in partnership with local governments and independent associations of peoples (Haufler 2013; Murphy and Bendell 1997). Supra-national organizations such as the United Nations often set the formal sustainable development goals, which are then interpreted by national governments. When the work is done by NGOs, they typically operate off private grants and grants from national governments. Frequently the focus is on countries in the global South, and efforts seek to promote economic development that preserves, protects, and often restores ecosystems, with the goal being a sort of harmony between people and the environment. Sustainable development is a contested concept, with no consensus over societal goals to achieve sustainability (Connelly 2007). This contestation is due at least in part to conceptual ambiguity, with some development theorists worrying that this conceptual ambiguity could serve as a cloak for dehumanizing and undesirable outcomes (Le'le' 1991; Richardson 1997). The view of the Church becomes critical in these programs and their implementation as these populations of South America, Africa, and increasingly in Asia are heavily Catholic, with the ontology of the people affected becoming of greater importance as more development agencies seek to do work in these regions. These policies 
affect not only local governments and industry, but also common people. This is especially important to understand due to obvious conflicts between Catholicism and the United Nations sustainable development goals, specifically those goals regarding population control, sexual liberation, and the creation of global governance alliances.

\section{Why the Catholic View Matters}

The Catholic Church is two things: a body of believers and a set of formal institutions united in a clearly delineated structure that has both highly centralized features and heavily decentralized components. The Church is growing, estimated at about 1.2 billion members as of 2014, with noteworthy growth in Asia, Africa, and other parts of the developing world (Inglehart, et al 2014). The relevance of the Catholic position on sustainable development is not limited to demographics. As a formal institution, the Church is conservative and reactionary in nature; by reactionary it can be understood that the Church reacts to outside pressure and calls for change slowly, and only after the demands placed on the Church have been analyzed through the lens of the mission of the Church and past decisions made by the Magisterium (the formal teaching of the Church comprised principally of the pope and various councils and Synods) whose purpose is to safeguard and conserve the doctrines and disciplines of the faith (Ripperger 2014; Franzelin 1875). For policy-makers, this is important because the tradition-oriented nature of the Church and its slowness to accept change can assist in promoting the interests of future generations. This slowness to change can mean that reform-minded popes like Francis can implement 
programs that focus on sustainable development and creating greater working relationships with NGOs and Supranational Organizations like the UN and those partnerships are much more likely to withstand the efforts of a successor who differs with Francis due to the presence of so many of Francis's appointees to the bureaucratic body of the Vatican, the Roman Curia (Ivereigh 2014). This serves the same purpose as the permanent bureaucratic class in the US government and similar governments around the world (Wilson 1975). This is a distinct possibility through the values of stewardship and solidarity, which assumes a responsibility for future generations. As an example of this, the Church has resisted calls for ordination of women for decades with no acquiescence in sight. Another example is the pastoral reforms of the Church leading up to and including the Second Vatican Council of 1962-65, which culminated in the expressed mission of the Church to include preferential treatment of the poor in the social instruction of the Church (Witgen 1966). The latter change came after decades of pressure from Latin American Catholics placed on the Bishops to include a greater role for the laity in the operations of parishes. This resulted in the institution of pastoral councils, the formation of national conferences of Bishops, as well as the calling of the Second Vatican Council itself (Adriance 1992).

The conservative reactionary nature of the formal hierarchy of the Church is due to both the structure of the Church and the guiding values, which are deeply rooted in the core dogma of Christianity. Giddens and Nunes define structure as the norms or set of transformational relations and simultaneous conditions that define what organizations can do when faced with outside change (Nunes 2004; Giddens 2000; cited in Joaquim 2006). These norms are combined with the understanding of authority, both political and within 
the Church, that the Magisterium of the Church teaches is proper. According to this view, authority is rooted in the moral order established by God, with those in positions of authority being in power due to the will of God. As such, changing the established order is to be taken with utmost care. Authority does not receive its legitimacy from itself, and thus cannot adopt rules and laws contrary to the moral order (John Paul II 1994). Thus, the Church is not able to change her formal teachings. Addressing changing social conditions requires care to ensure that those social conditions can be addressed in ways that conform to the natural moral law.

The Papacy has a political role as leader of the Catholic Church, even among nonChristians and non-Catholics. This political role is not necessarily in the role of the pope or even the bishops acting as a magisterial body, but in exercising influence in the world of politics and in the broader society. Aside from being the most visible religious leader in the world, which lends itself a certain level of authority, the pope in the modern world is as much a political activist as he is a religious leader, and the two roles have become inseparable. An example of this is the reaction to Pope Francis's recent visit to the United States, with the media treating the pontiff like a rock star and bringing American Bishops on television to comment as figures of authority on interpreting what the Pope said at any given event.

The Bishops have a similar effect, though without the celebrity. In the contemporary western world, they operate either with local political authorities or with national governments on issues related to immigration, environmental conservation, and other areas 
of interest that the Church takes an interest in, especially when the issue of government contracting is concerned. Often a national conference of bishops will release white papers announcing the proper Catholic response on a given issue (Butkus and Kolms 2007). Official documents of the Catholic Church attempt, for example, to address various ecological problems. One contemporary example of this is in the Pastoral Letter on the Columbia River Watershed, released by the US Conference of Catholic Bishops (USCCB) in 2001. The Bishops have felt free to interact with the political system as necessary, typically only in the capacity of making public comment on proposed action or lobbying the lay faithful to support a proposed ballot measure, as was the case in Portland, Oregon, when Archbishop Alexander Sample endorsed a controversial ballot measure related to immigration (Catholic Sentinel 2014). These communications are political in nature and are not limited to Catholic audiences. The intended audience for Catholic Social Teaching is primarily Catholic laity but also includes people outside the Church, for the magisterium of the Church considers itself to be a teacher to the world, typically through the means of the Bishops of the Church. This teaching authority is not considered part of the magisterial or papal, even when exercised in ways commensurate with Catholic Social Teaching (Bertone 1997).

\section{Sustainability and Environmental Theory: The Secular Debate}

The growth of Catholicism in the global South is important to understanding the salience of Catholic Social Teaching as it relates to sustainable development. Catholics are heavily represented among populations in the countries and regions most frequently the 
subject of sustainable development efforts by international and local authorities, and the norms of social sustainability require that the values of affected populations be taken very seriously in development efforts (Ives and Kidwell 2019; Cooper and Vargas 2005). An important issue affecting implementation of sustainable development programs is a clarity of understanding the concept of sustainability. Presently, sustainability is a complicated concept that is mired in conceptual ambiguity, which itself has implications for applying Catholic Social Teaching in practice. There are two principal schools of thought in the philosophical debates on the issue: anthropocentrism and deep ecology/spiritual. I intend to present an overview of both schools of thought that presents the central claims and tendencies of each position. It is not my aim to delve deeply into these arguments, but rather to understand the foundational theoretical positions that informed policymaking, which has in the discourse on political theory and sustainable development largely ignored the Social Teaching of the Catholic Church. Both the anthropocentric and the deep ecology traditions are complex, and the potential exists for not giving either schools of thought their due in providing a brief overview of essential ideas. A literature review that covers those schools of thought will provide foundation for those ideas in this dissertation at the end of this chapter.

Conceptually, sustainability is rooted in the early politics of conservation and preservation in the US and Germany (Guha 2000; Pepperman-Taylor 1992). This work would be built on the scientific utilitarianism of Jeremy Bentham, who insisted that the only things that are knowable are those that can be viewed and scientifically verified (Bentham 1840). The scientific management movement of the progressive era is important 
contextually to understanding the period that did the early work that permitted the modern sustainability movement to be born (Cummings and Brideman 2014). This movement sought to scientifically manage American society, beginning with Gifford Pinchot's work in the US Forest Service, which saw the beginning of the professionalization of natural resource management and the US government in general. The aim of this movement was the imposition of scientific efficiency for maximum economic growth (Nelson 1999 3). This was part of the larger rise of the disciplines of Public Administration and Political Science as a response to the governance crisis of the Progressive era (Lee 1995).

Critical figures in the development of conservation, preservation, and environmental politics were American historical figures such as John Muir (1917), Gifford Pinchot (1910; Pepperman-Taylor 1992), Aldo Leopold (1991), and George Perkins Marsh (2001), as well as German figures like Alexander von Humboldt (1889), and Dietrich Brandis (1906). Initially, the figures concerned with the state of the environment and the human relationship to nature could be divided largely into two camps: the managerial and the spiritual. The managerial school is under the anthropocentric category and has been argued to have been the source of much modern non-spiritual anthropocentrism. The managerial camp would find the greatest expression of the assumed values in the work of the German, British, Indian, and US Forest Services, and would place a heavy emphasis on administration of forests as resources for indefinite future use by generations far into the future (Guha 2000). While this rise of progressive management theories appears to be purely technical on the surface, in reality this reflects the importance of political science and political theory in policy and governance. The roots of the debate about land 
management and the broader understanding of human beings and the relationship we have with nature is embedded deeply in the western philosophical tradition. The postreformation Enlightenment era of thinking is the basis for much of this philosophy, with the attendant utilitarianism and liberal assumptions about human beings having a right to exploit nature purely for resource and wealth considerations (Cortner, Moote, and Moote 1999). The progressive scientific management revolution in the forestry service and beyond is the clearest example of this anthropocentric thinking that White is alluding to, as opposed to the Latin West tradition of Christianity.

The spiritual movement would arise as a backlash against the managerial ethics of the various agencies tasked with preserving natural resources for future use. The champions of this opposition would include Muir, Leopold, and Patrick Geddes, to name a few (Guha 2000). The spiritual opposition sought value in nature itself, not from a utility to humans but due to the perceived intrinsic value of nature itself. For example, Sir Patrick Geddes was a planner known for his distrust of the technocratic paradigm, which he saw undermining the connection of people with place. Geddes offered an alternative view that sought to recognize the fundamental unity between nature and culture. "Our greatest need today is to see life as whole, to see its many sides in their proper relations; but we must have a practical as well as a philosophical interest in such an integrated view of life," (Geddes 1957). Geddes was particularly influential in the development of analysis of geography, environments, and human communities in a way that made clear the deep connections humans have with the natural environment. Social networks were of more value than state intervention for Geddes, Muir, and Leopold, as the state was seen as either 
complicit in mismanagement and appropriation of nature or lacking the competence to adequately protect vital natural areas (Meller 2005; Guha 2000). These two schools of thought are represented in the contemporary debate between anthropocentric and ecological schools in the theoretical literature. Jacob, citing Naess, describes this divide as one between Deep and Shallow Ecologies, with Shallow ecology being the model for what is today called anthropocentrism or the managerial approach to environmental issues:

Shallow perspectives are characterized by an emphasis on the need to apply ecological principles to ensure better management and control of the environment for human benefit. This leads to a treatment that depicts environmental problems as isolated contradictions in the prevailing style of development. Deep ecology perspectives, however, start from the premise that the ultimate cause of extant environmental problems is the anthropocentric nature of Western development. They interpret environmental problems as proof of the need for an alternative ecological worldview premised on the idea that humans are part of the living system itself and that human interaction with the rest of nature should be dictated by this imperative...(Jacob 1994, 479).

I examine each of these figures as well as the contributions of other theorists and practitioners to understand the divide and conceptual origins for both approaches to understanding the human interdependence with the environment and with one another. The assertion from theorists like Lynn White that anthropocentric modes of thinking are rooted in Christianity is affirmed (White 1967), though this dissertations shows that one particular form of Christianity (Calvinism) has influenced both ecology and anthropocentrism, to which an alternative schema is needed to change the discourse. An alternative is needed because Calvinism is not representative of every form of Protestant Christianity, let alone Catholicism. The influence of Calvinism in the understanding of Christian metaphysics and 
its influence on social organization on the part of critics of Christianity does not enable an accurate critique of Christian societies and values. In addition, the non-religious and nonspiritual dimensions of the sustainability movement are rooted in what some authors call an old heresy, specifically the ancient anti-Christian heresy belief in Manicheanism (Derrick 1972). Both are presented to better understand those idea systems and their influence on contemporary thinking.

The origins of the modern environmental movement can be traced in western thought back to the Industrial Revolution and the reaction to it from early Modern thinkers and the civil servants they influenced. Theorists and commentators whose work would influence the ecology schools of thought today that were critical in this period include Thoreau, John Muir, Emerson, and Aldo Leopold (Scruton 2012; Guha 2000) as well as the lingering influence of the protestant reformation. Along with British botanist Dietrich Brandis, these figures were essential in promoting a sort of scientific authoritarianism that was principally concerned with efficient management of resources, with little concern for local populations that were impacted by administrative decisions made by officials far from affected areas (Guha 2000, 145; Lee 1995, 37). This thinking is presented in the classic work A Sand County Almanac, where Aldo Leopold argues that moral concepts be assessed in terms of the tendency of concepts and policies to produce or preserve what Leopold called "the integrity, beauty, and stability of the biotic community" (Leopold 1989, 37) which raises the question of whether economic systems requiring constant growth are compatible with the finite resources nature offers. 
Anthropocentrism and deep ecology are terms that must be defined before moving forward. The anthropocentric position makes the claim that the Earth is primarily for the use of human beings, creating a division between humankind and nature. The two principal 'green' philosophical views can be understood through how humans and nature are viewed. To start, anthropocentrism can be understood in the way John Barry, famed Irish Green Republican theorist, describes humanity's relationship to the environment in the context of human rights, noting that human beings are "ecologically embedded. That is, humans are utterly dependent upon, and vulnerable to changes in, their relationships with the nonhuman world," (Goodhard 2013, 381). The language of rights underscores this claim, which recognizing that humans are part of nature. The approach of Barry is one of ethical anthropocentrism that seeks to bridge the classic divide between humans and nature through this embedding of humans in nature, which makes the case that human beings have a right to a stable and healthy environment (Barry 2002, pg.18). This is similar to the Catholic view that is presented later, though the Catholic view is not anthropocentric. Rights are envisioned as a reflection of duties, which is a classically republican understanding of rights. These rights include the duty to ensure the level of environmental protection necessary to exercise rights fully, as well as access to political power and access to a safe, stable, and fruitful environment that enables human well-being. Concern for the well-being of the environment is purely rooted in the concern about the effect that environmental degradation will have on the quality of life for humanity, a practical consideration almost worthy of the utilitarianism of John Stuart Mill.

Reflecting the concern for human rights, anthropocentrism has an obvious focus on 
species survival with long-standing beliefs in national sovereignty. This is reflected in the tendency of anthropocentric arguments involving the need to protect national interests, economic protectionism, or the "greening" of capitalism. Contemporary anthropocentric arguments for environmental protection are typically pragmatic, with the almost revolutionary recognition that human survival is a profound motivator for promoting movement on environmental issues. Often anthropocentric thinking is characterized by human beings having a relationship with the Earth based on exploitation and presented as either a natural reality or at least one that would be devastating to the quality of life and freedom of persons should it be altered. It can be said that much of anthropocentric thinking involves upholding of the economic and social status quo (Pope Francis 2015).

On the other side of the spectrum are the deep ecologists, who share salvationist politics in common with their anthropocentric counterparts (Scruton 2012; Lee 1994). Salvationist politics in the deep ecology school of thought are characterized by Scruton as the infusion of the characteristics of religious redemption in discourse that seek to create a kind of heaven on Earth (Scruton 2014, 85). According to Scruton, the deep ecology movement was founded by Norwegian philosopher and activist Arne Naess. Its variants offer a transcendental struggle against an ontological threat. Whereas anthropocentrists will address environmental issues out of a sense of utility and human well-being, deep ecologists will see environmental issues as threats to not only human existence but life itself. The ontological similarities are described by Scruton, whose description is worth quoting at length: "The current emphasis on climate change should be considered in this light. Global warming is not the kind of small-scale issue that can be addressed by 
individuals, or which slots into the normal modes of practical reasoning. It is a transcendental issue, concerning the state of humankind as such. Like original sin, it weighs on us all, and like original sin it might seem to require a salvationist solution," (Scruton 2012, 88, emphasis in the original). The salvationist politics are a common thread in environmental politics across the ideological spectrum.

The view from the Catholic Church has been characterized by Pope Francis as "integral ecology," which is a meeting halfway between anthropocentrism and deep ecology. Integral ecology is an approach that is human centered in that it challenges people to take a larger view about the role they live in the world to include sustainable environmental ecology, protection of all human life, concrete acts of solidarity with the poor, as well as altering economic behavior and bringing development in line with a morality that fosters human social arrangements while simultaneously connecting people with creation (Glatz 2019). This view is clearly meant to bridge the divide between the anthropocentric and deep ecological views, in part due to the man-centered nature of Christianity (White 1967) but also in part because of the role stewardship plays in Catholic Social Teaching, which will be explored in a later chapter.

In policy, politics, and economics the anthropocentric view dominates discourse, with discussion about the human relationship with the environment and with one another taking on the assumptions of those with a managerial worldview. The managerial approach to addressing the numerous environmental crises in modern history emerged due to the anthropocentrism of the culture and education (Shnayder, Van Rijnsoever, and Hekkert 
2015; Kopnina 2014). This worldview can be best understood in the context of how issues related to economics and environmental degradation framed by policy makers and those engaged in the implementation of those programs. These problems are typically addressed by policy managers in the US and Europe as problems that require centralized management by the state, NGOs, or private large-scale enterprises that are heavily influenced by politics and science understood through the lens of political needs. One example of this is the review process of the European Union that judges the merits of new development projects through the understanding of the Precautionary Principle, which is defined by its adherents as "taking preventive action in the face of uncertainty; shifting the burden of proof to the proponents of an activity; exploring a wide range of alternatives to possibly harmful actions; and increasing public participation in decision making," (Kriebel 2001). Another example is the debate from the Columbia River Watershed Waterways issue of the early 2000s, which pitted farmers and fishermen in opposition over water rights. That debate was focused on human needs primarily, and the needs of the biosphere came much later (CRWC 2001).This can be considered 'anthropocentric' not only because it is focused on the human experience and needs (indeed, virtually all of policy can have that accusation leveled against it) but because it is purely materialist in nature due to the debate focusing on economics. This contrasts with the contemporary Catholic view, which includes duty to protect the created world and relationship therein. Understanding this is at the most utilitarian level of interest to policy makers as this relationship could mitigate the disordered consumerism that is at the heart of both the development crisis and the environmental crisis, and is one avenue of addressing the human element of this crisis that 
those in the developing world appear to be more open to embracing, especially in light of the embracing of environmental causes by Pope Francis as seen at both in Laudato Si and at the 2019 Pan Amazon Synod, which featured indigenous peoples from South America in prominent roles. The Synod was underscored by Francis's frequent reminders of the dangers of consumerism. Recognizing the environmental crisis is not new for the Church, as I demonstrate in later chapters, but the clear focus of Pope Francis is new. The underlying logic of Pope Francis's encyclical Laudato $S i$ illustrates this recognition and the recognition of the integral good of creation, with emphasis on the common good and human dignity while incorporating ecological concepts such as the natural or created world having intrinsic value, including animals and biospheres. Pope Francis reminds those who will listen in Laudato Si and beyond that all things are connected. This interconnectivity in undermined by consumerism and other activities that turn the person and even cultures inward instead of recognizing this interconnectivity. Laudato Si has had an impact on the environmental discourse and policy making, with the encyclical and efforts of Pope Francis aiding in the ratification of the UN General Assembly's 2015 Sustainable Development Goals, and the adoption of the Paris Climate Agreement in December of 2015 (Burke 2018).

These values of Catholic social teaching, and especially of integral ecology, are embodied in the work of the St. Kateri Tekakwitha Habitat Program, which combines an environmental ethic with work in social justice that is in keeping with the social teaching of the Church. Located in the United States, this organization states the following as the motivation behind its organizational mission: 
The Saint Kateri Conservation Center offers a faith-based program to inspire Catholics and others to restore yards, gardens, schools, farms, parks, forests, rivers, and wetlands into healthy habitats for people and wildlife. We do this close to home, where we live. The Saint Kateri Habitat Program encourages individuals, parishes, schools, religious orders, and working landowners to restore their natural homes in a way that praises God and fosters a greater connection between people and nature. With a special focus on Catholic faith and social teaching, the Saint Kateri Habitat Program provides living, sacred spaces for people to engage directly in the care of God's creation at home and in their communities. By restoring habitats with reverence for our Creator, the program draws people closer to God and his Church while protecting the integrity of creation, (2019 St. Kateri Center).

An implementation-level example of anthropocentric thinking can be found in contemporary forest management practices, which feature decision-making that often takes place hundreds or thousands of miles away from managed lands and the local economies that rely on them, with little concern for those whose livelihoods depend on forest products (Smith, Lee, and Newsome 2006). The Klamath Falls water debacle in Oregon in 2002 and the subsequent debates and hearings in the years after is the classic modern example of this, which featured farmers and fishermen and environmentalists all locked in a debate about the rights to water. In 2002, the Department of Interior sided with farmers in this debate over water that resulted in the largest fish die off in the history of the American West (Fogerty 2007, para. 10). This decision was ultimately made in Washington, DC, leading to farmers getting a short term political victory but in the long term the fisheries were devastated, illustrating the need to consider a more integral approach to understanding the relationship between ecology and economics, and the role subsidiarity and solidarity can play in these debates (CRWC 2001, pg. 2;Senate 2003). Defenders of this federal action that were decided far from the communities impacted say that when implemented in an 
enlightened manner, the decision-making process can achieve goals that are free from local political constraints and undue influences from local actors (Keulartz 2012). This position reflects the nuance needed to understand the real implications of subsidiarity, which is explored in greater detail in Chapter 4. The historic context of the Klamath Falls waterways debate and its roots in prior timber disputes illustrate the need to carefully understand the complex tradeoffs involved in this debate.

Moving forward, the purpose of this examination will be to explore the framework of Catholic Social Teaching as a compliment to the sustainable development body of knowledge in order to better equip policy developers, program implementers, and theorists to solve the critical problems facing the world today, especially in the developing world or global South. CST has a long history of addressing social, economic, and political issues that, as I demonstrate later, has included environmental thought in the analytic framework since the 1960s. This is due to the development of Catholic Social Teaching over the course of 150 years that incorporates much of both the anthropocentric and biocentric understanding of these issues through the concepts of stewardship, subsidiarity, and solidarity, with the end result being a vision of an integral ecology that allows the created world to thrive while ensuring human flourishing. The following chapters will explore this system of thought, the Church's authority to teach, and Catholic Social Teaching in the framework of the three legs of sustainability (social, economic, and environmental). 


\section{Literature Review}

The related literature outside the body of Catholic primary and secondary sources is critically important for understanding the subject I am presenting. A brief examination of the relevant literature is essential for understanding concepts such as solidarity, anthropocentrism, deep ecology and biocentrism, as well as basic concepts of sustainability and sustainable development. The review of this literature will add clarity to this dissertation as the work unfolds.

An essential component of Catholic Social Teaching is subsidiarity, and it is a concept that has been studied outside of the Catholic intellectual tradition extensively. The concept of subsidiarity is widely and inaccurately cited as an essential component of federalism, with federalism being the most subsidiarity-respecting governance arrangement in operation today (Golemboski 2015). This argument is made by numerous scholars. Bermann (1994) states that the concept of subsidiarity is both over sold in the European Union and ignored in the United States while simultaneously arguing that "the principle of subsidiarity is not only a plausible response to the federalism patterns that have developed in the Community over the past thirty-five years, but a compelling one," (Bermann 1994, 335). This is based on Bermann's thesis that subsidiarity is not practiced while it is being preached. For true federalism to work in the increasingly centralizing European Union, subsidiarity is essential, due to it being based on the values of local control, cultural preservation, and the preservation of local identities in an argument that equates subsidiarity with localism (Bermann 1994, 340). A different understanding more 
closely connected to Catholic Social Teaching and the history of Catholic thought is presented by Aroney (2007), who demonstrates that subsidiarity as understood by Aquinas and those who came after him was hierarchical in nature, which Aroney describes as a "subsidiarity from the top," (Aroney 2007, 165). This conception of subsidiarity is rooted in the development of theory from Aristotle through Aquinas and beyond, through the work of Aquinas's students into the $16^{\text {th }}$ century. This conception is focused heavily on the notion of a small but central power that exercised power over a top-down society that bears little resemblance to the Enlightenment-era thought that birthed modern theories of federalism (Aroney 2007, 161-220). A possible solution to this in some of the literature is seeking redress with the courts in the United States, which has the traditional authority of making declarations of constitutionality of decisions made by state and federal actors. One such proposal suggests that subsidiarity could be defined and enforced by the courts, which would carve out spheres of authority more proper to local governments than is currently practiced, which could then serve as an example for the European Union. This would provide greater power to the courts than they already have, at least in theory (Young 2002, 1676-1680).

These various arguments have led to a conceptual ambiguity, with subsidiarity being invoked by a diverse cast of scholars and policy implementers, leading to definitions and conceptions of subsidiarity that are at odds with the Catholic origins of the concept. This is best expressed by Golemboski when he states "In light of subsidiarity's plural interpretations, the crucial task is to ensure that the common label does not facilitate misleading conflations of distinct theoretical commitments. Unfortunately, this is precisely 
what occurs regularly in discussions of subsidiarity. Specifically, the principle is identified as originating in Catholic social teaching and is then explicated or applied in such a manner that unwittingly betrays how far behind it has left those origin," $(2015,527)$. Often the literature focuses on the state as actor, when the state according to Aquinas is but one of several actors. An example of this is a common definition of subsidiarity as a form of federalism such as: "Subsidiarity is the idea that matters should be decided at the lowest or least centralized competent level of government. We understand that subsidiarity grows from the belief that individual rights exist as a matter of natural law" (Calabrisi and Bickford 2014, 5). The authors of that statement briefly mention families and nongovernmental associations but return to place the central focus of subsidiarity on government action, with little focus on free associations. Volunteer associations that exist outside the state are an essential part of this system, operating as legitimate places of decision-making with no role necessary for government in many circumstances (Beer 1989, 277).

Another essential component of my analysis is the concept of anthropocentrism. As an ethical position in the environmental debate, anthropocentrism and non-anthropocentrist positions represent a range of ideas that vary along an intellectual and ideological continuum dictated by their relative individualism or collectivist ontologies (Burchett 2016). At the heart of the anthropocentric perspective in the environmental debate lies the argument that if people collectively step too far outside the analytic framework of the human perspective, instead of moral horizons being expanded, moral perspectives will either collapse or be unrecognizable in practice. To achieve the goals of biocentrism and 
deep ecology requires a human-centered approach, for to do otherwise is a hopeless quest (Grey 1993, 463). This would require a divorce of human valuation as we understand it, through the mechanism of disentangling the concept of human needs from the particular perspective to a collective one, which can best be described as an impersonalist perspective (Plumwood 2002, 130).

At present there is a lack of a well-accepted system of thought that can serve as a foundation for environmental protection, for either the biosphere or even animal life, that considers the needs of human beings, which has led to controversial methods for conservation that are often criticized as tyrannical (Paquet and Darimont 2010, 178). This critique is rooted in the recognition that much of the macro-level conservationist efforts reflect the neoliberal or technocratic international paradigm that is hostile to nature. One proposed solution is to push an alternative path for multispecies abundance, which makes takes animal welfare and the health of the biosphere as a priority. This is not at odds with ethical anthropocentric concerns, which places human beings into the environment both for moral reasons and for analytic purposes that seek solutions to the environmental crisis (Collard, Dempsey, and Sunberg 2015, 322).

Biocentrism and Deep Ecology are heavily influential in this debate as well. Rooted in the work of Naess, deep ecology distinguishes itself from the anthropocentric tradition by embracing "biospheric egalitarianism", which is the view that all living things have intrinsic value regardless of any usefulness to humans they may or may not possess. Deep ecology represents the view that all living things are alike in having value in their own 
right, independent of their usefulness to others. The deep ecologist respects this intrinsic value, taking care, for example, when walking on the mountainside not to cause unnecessary damage to the plants (Brennan 2002, para. 3.1). Deep ecology rejects the atomized individual of anthropocentrism and liberal analysis, which separates the human person from the rest of the world, which leads to what Naess characterized as "selfish behavior" towards the rest of the world. This was to be cured by the adoption of the relational, total field image, which places humans as a part of nature in relationship with the rest of life (Naess 1973, 95).

Taylor (1981) presents what is often called the class biocentric perspective, which he defines as an environmental ethics system that places respect for nature in a central role of a life centered system. Taylor contrasts a life-centered system to human-centered ones, claiming that humans have a moral obligation to plants and animals as members of Earth's biotic community, requiring humans to recognize a moral duty to protect plant and animal life for its own sake (Taylor 1981). Central to this thesis is the assertion that actions based on self-interest are not limited to humans. Animals and plants act in accordance with selfinterest as well. Each animal and plant in the natural world seeks out the good for itself in ways that are similar to that of a human (Taylor 1983, 237). This sense of self-interest permits animals, including humans, to hunt, acquire natural resources, and to pursue other activities essential to the personal good as long as they adhere to the concept of basic interests, with non-basic or inessential interests not being included, such as the use of ivory or fur coats. The essential aspect is an integral view of the biosphere with the recognition of the interests of all life, not merely the life of human beings, though human needs and 
interests are included in the formulation and given due weight given that humans are making these rational judgments, which separates biocentrism from the more radical deep ecology movement (Calicott 2013, 224-229).

This dissertation has a core concept that enables a form of policy action. That core concept is sustainability, and that action is sustainable development. Sustainability is the goal of achieving a relationship with the environment between humans and nature where people can meet their needs while enabling natural spaces and biospheres that had been damaged in the $19^{\text {th }}$ and $20^{\text {th }}$ centuries industrial and post-industrial development to thrive. There is hope that this can be achieved, as the late $20^{\text {th }}$ and early $21^{\text {st }}$ centuries have shown greater efficiency in resource extraction with reduced environmental impact, ranging from areas such as mining to agriculture and fishing. The goals of achieving sustainability are global in range and require international action to achieve and do not have an explicit endpoint (Kates and Clarke 1999, 1-5). Sustainability is conceptually embedded in the natural sciences and is viewed in the framework of systems, with the recognition that any area of investigation, development, or policy action should not consider areas of focus in isolation, but should instead envision economic, social, and environmental concerns as an integrated whole, with recognition of the interlinked nature of biospheres and the environment broadly, as well as the deep connectivity of human action in various realms to other areas of the human and natural experience (Schianetz and Kaganagh 2008, 605). Sustainability thus requires a recognition of the integral relationship between humans, the environment, and the relationship between the internal workings of the complex environmental system, with the goal of preserving and strengthening existing systems both 
for their own sake and for the sake of human beings in the future. The human dimension is comprised of the sociopolitical systems, as well as culture, psychology, and human behavior (Brown 2006, 4-18). The emphasis and inclusion of the social dimension of sustainability and its direct link to ecological health is essential to addressing the issue of long-term environmental health and human thriving, requiring the development of a complex interdisciplinary approach to research and policy development to preserve and enhance social systems in the environmental crisis (Ostrom 2009, 4-6).

The literature on sustainable development is built on this complex concept and essential policy documents that emerged as a result of international conferences held to address the environmental crisis. It is built upon the interconnected areas of social, economic, and environmental sustainability (Murphy 2012, 15-17). Much of the framework in the policy and social justice discourse comes from several international summits and documents born from them, including the Brundtland Commission Report, which defined the term sustainable development as meeting the needs of the present without compromising the ability of future generations to meet their own needs (Brundtland 1987, 43). The Brundtland Commission was convened as a result of the 1972 United Nations Conference On The Human Environment and the inability of that conference to address or conceptualize the environmental crisis in a manner that enabled meaningful action. That commission not only provided the definition of sustainable development but also its focus. The needs of future people were defined with the purpose of giving priority to the poor, the recognition that technology and social structures limited the ability to meet present and future needs, and the requirement that societies change in 
order to facilitate the needs of people everywhere. An emphasis is placed on societal change that emphasizes social equity within and between generations. This requires addressing consumption patterns to bring them within the confines of ecological capacity. Economic growth in the poorest countries is to be emphasized and consumption and economic activity adjusted in those countries that overconsume must be changed (Brundtland 1987). An emphasis on the plight of the poorest countries is of such an emphasis that it cannot be overstated.

Five years after the Brundtland report was issued the first Earth Summit was held in Rio de Janeiro, which issued several documents meant to reframe the development question in the post-Cold War environment. The summit was held to promote member states working together in recognition that sustainable development was not achievable for most states in isolation. Collaboration was the focus, with non-governmental organizations included in the focus. Several documents emerged from the Rio Summit: Agenda 21, the Rio Declaration on Environment and Development, and Forest Principles (Friedman, Hochstetler, and Clark 2012, 3-17). Agenda 21 was a non-binding action plan for multilateral government cooperation for the achievement of the sustainable development goals by 2021, which included combatting poverty (especially in the developing world), changing consumption patterns, achieving population stability, promoting of health infrastructure, and a participatory decision making process, as well as including goals for natural environment protection and restoration, protecting and empowering women, children, ethnic minorities, indigenous peoples, and small and local businesses. The goals were to be implemented through education, development of new technology, government 
leadership, and business embracing these goals (Sitarz 1993).

The Rio Declaration on Environment and Development (or Rio Declaration more commonly) was a document that promulgated 27 principles for development. The most important of these principles were the Precautionary Principle and the Polluter Pays Principle. The Precautionary Principle imposes a burden of proof on those who engage in activities that create possible risks, and it requires regulation of activities even if it cannot be shown that those activities are likely to produce significant harms (Sunstein 2003, 1003). The Polluter Pays Principle (PPP) requires the polluter to internalize the costs of preventing, controlling, and cleaning up pollution (Grossman 2006, 3). Both the Precautionary Principle and the PPP were rooted in the 1972 UN Conference on the Human Environment but had their principles reexamined and re-presented to meet the needs of the present day. Both values represent the values of stewardship in the policy realm, as well as subsidiarity in that the need for regulation begins with the business or individual taking personal action to address the needs of the ecological preservation and protection. This is the core of the internalization aspect of these two principles (Sunstein 2003; Grossman 2006).

The Forest Principles document is also a non-legally binding agreement that was the result of negotiations between the developed countries of the Global North and the developing nations of the Global South. The document called for the countries of the world to embrace a holistic vision of the relationship between humans and the forests of the world, while enumerating several principles that recognized the right of countries to engage in 
forestry practices for economic purposes. Greater international cooperation to manage forests and related issues was called for while recognizing national sovereignty as an inalienable right. Forestry resources are called to be managed with respect to the needs of future generations in keeping with the definition of sustainability from the Brundtland Commission Report, with the needs of local communities have participatory rights in natural resource management in keeping with the values of subsidiarity (UN 1993, para. 39).

In 2002, The World Summit On Sustainable Development was held in South Africa. Nicknamed "Rio+10," this summit was convened to discuss sustainable development organizations. The principal document promulgated from the summit was the Johannesburg declaration, which placed an emphasis on multilateral cooperation to achieve sustainable development goals. The focus was on "the worldwide conditions that pose severe threats to the sustainable development of our people, which include: chronic hunger; malnutrition; foreign occupation; armed conflict; illicit drug problems; organized crime; corruption; natural disasters; illicit arms trafficking; trafficking in persons; terrorism; intolerance and incitement to racial, ethnic, religious and other hatreds; xenophobia; and endemic, communicable and chronic diseases, in particular HIV/AIDS, malaria and tuberculosis" (Johannesburg 2002, para. 19).

These conferences illustrated the conflict between what became known as the Global North and the Global South. The 1972 conferences barely included the southern nations and focused on northern environmental concerns. By 1987 the concerns of the 
southern nations were included under the rubrics of sustainable development, which had been interpreted by northern nations as the need to embrace ecological stewardship in economic development while in the south this was interpreted as the right to develop first and foremost. By 1992 this divide was on full display in Rio, with southern delegates understanding Rio to be a conference on development, and northern delegates believing the conference to be on the environment (Wapner 2003, 5). The divide between the North and South is based on historical development, and past characteristics due to relationships with Northern and Southern states, as well as to some degree the perception of the decline of the United States and its global influence and the rise of the nations of the southern hemisphere (aka, the Global South), especially the BRICs nations: Brazil, Russia, India, and China. Some scholars contend that this is due to the decline of the United States in its global leadership and power projection capabilities, especially in geopolitics and economics, most notably in the global climate negotiations where the inability of the US to maintain international alliances was evident (Roberts 2011, 777-780). Others suggest that these claims are grossly exaggerated and instead suggest that the rise of these powers is a reflection of the United States' continued and distinctive role in global leadership and development (Worth 2015, xi; Kiely 2016, 2). The consensus is that the rising influence of the Global South is clear, regardless of the cause, and that this has profound implications for justice, economics, geopolitics, and the climate (Gray and Gills 2016, 564). 


\section{Chapter 2 Authority and Catholic Social Teaching}

Understanding what Catholic Social Teaching is first requires a brief examination of what authority the Catholic Church claims and possesses to offer opinions that should be taken seriously on issues related to economics, politics, and the environment. The historic claims of the Church provide some authority among Catholics for presenting this sort of teaching, but as we will see, this hasn't necessarily translated into obedience among Catholics on these issues either or even in the recognition that the Church possesses the authority to teach on hot button social issues Different interpretations of Catholic Social Teaching by organizations like the Acton Institute, Discovery Institute, and others that present CST in a framing that defends American economic interests and the laissez-faire economic order favored by some American industrialists has been rejected by American bishops like the now retired archbishop of Galveston, Joseph A. Fiorenza. The archbishop has accused Acton and others of disregarding the social teaching of the Church and reducing CST to a matter of mere prudential judgment (Rocca 2012). Others have stated that the popes lack the expertise to comment on economics and environmental concerns (Zmirak 2017). This is not the historic opinion of the faithful, nor does this view conform to the history of the Church, nor is it a new phenomenon in the $21^{\text {st }}$ century (Coloumbe 2020). But for the purposes of this exercise a brief examination of the historic claims of the Church will suffice, followed by the authority the Church possesses as an economic and political actor on the world stage, before an exploration of what Catholic Social Teaching is as a body of philosophical and academic literature with implications for the 
world of practitioners.

The historic claims of the Church are important to understanding the authority of the Church on this issue regarding the relationship between the Church and the 1.2 billion Catholics around the world. Among Catholics, the claim to teach in all areas of social life is rooted in the historic claims of the Church as being the Church founded by Jesus Christ on the Rock of Peter. While the historicity of the claim in anthropological, archaeological, and historical terms is fascinating, the veracity of the claim need not be demonstrated here. Rather, of greater importance is the claim that this authority historically was exercised outside the realms of theology, which include the political influence exercised by popes throughout the ages on matters of peace, negotiation, and even major policy changes across the west such as the case of Pope Paul III's decree of 1537 which forbids the enslavement of indigenous peoples in the New World (Paul III 1537). The role of the pontiff in influencing political affairs outside the Church can be demonstrated by returning to the claim made by Esolen (2012) and others that Leo XIII's writings were rooted in the philosophy and theology of St. Thomas Aquinas. An example of this is the letter of St. Thomas Aquinas de Regno, which was Aquinas's main foray into political theory, where Aquinas emphasizes the stability of the natural or secular political order, a claim that is reflected in the papal writings of numerous pontiffs through the ages and consistently applied regardless of the form of political order that dominates a given epoch of history (Aquinas 1997). Other examples including the writings of councils such as the Council of Chalcedon in the fourth century that banned the economic practice of usury, which is an example of an early social teaching of the Church (Hefele 2014). The popular narrative that 
Catholic Social Teaching originates with Leo XIII in the late $19^{\text {th }}$ century is erroneous due to the fact that the Church has exercised this function since the time that Christianity was legalized in ancient Rome. Catholic Social Teaching, as a formalized subset of the teachings of the popes, dates to the papacy of Leo XIII but in practice was part of an integrative body of work of the popes and magisterial authority of the Church prior.

The Church has always argued for the social kingship of Jesus Christ, where Christian rulers and politicians do not thrust Christ out of consideration or their lives when working for the common good of society. According to this view, society must be ordered in accordance with the natural law, and all of creation must recognize the divinity of Christ. If, as the Church teaches, all must be subject to the kingship of Christ, then issues related to economics, politics, ecology, and any other public interest problem are de facto problems of Catholic Social Teaching, and the rules of the faith must guide Catholics (McCall 2008; Davies 1992). An example of this integrated approach to these issues comes from the most recent Apostolic Exhortation of Pope Francis, Querida Amazonia, which illustrates these principles working in unison:

At the same time, the inculturation of the Gospel in the Amazon region must better integrate the social and the spiritual, so that the poor do not have to look outside the Church for a spirituality that responds to their deepest yearnings. This does not mean an alienating and individualistic religiosity that would silence social demands for a more dignified life, but neither does it mean ignoring the transcendent and spiritual dimension, as if material development alone were sufficient for human beings. We are thus called not merely to join those two things, but to connect them at a deeper level. In this way, we will reveal the true beauty of the Gospel, which fully humanizes, integrally dignifies persons and peoples, and brings fulfilment to every heart and the whole of life, (Francis 2020, para. 76). 
The Church teaches that the Gospel message of Christ is not only the key to the salvation of souls but, when applied properly, orients the cultures and nations of the world to the reign of Christ the King while simultaneously respecting the uniqueness of each culture that is not in conflict with the Gospel. Pope Francis's statement in Querida Amazonia reflects this in the call for "better integrat(ion of) the social and the spiritual, so that the poor do not have to look outside the Church,"(Francis 2020, para. 76) for the Church, through the preaching of the Gospel and the teaching of the implications of the Gospel in everyday life, offers a path to the poor for realizing a society that is stable, equitable, and sustainable from one generation to the next. As will be explored in brief later, the Gospel message is part of the intellectual foundation of Catholic Social Teaching, with the aim of bringing the social reign of Christ the King into fruition.

As might be imagined, not all Catholics agree with the claim that the Church has the authority to teach on a broad array of issues. Some publicly state that the popes lack the competence to make such public pronouncements. One example of this is the claim made by organizations such as the Acton Institute (a Catholic public policy think tank based in the United States) that much of Catholic Social Teaching involves laying the blame for social ills onto others without offering concrete, workable solutions (Acton 2018). This view is fairly widespread, especially in the liberal and social democracies of the West, where economic liberalism reigns and the errors of what Leo XIII dubbed "Americanism" reign supreme, the latter of which is the view that the rules and the living of the life of the Christian should be made relative to the context of each nation-state (Leo XIII 1899). It is sufficient for the purposes of this examination to state that the Catholic Social Teaching is 
controversial in some circles, especially on issues of economics and political arrangements.

The issue of the authority of the Church on the world stage is more complicated. Earlier it was stated that demographic considerations make the case for the Church being a considerable force in the community of states. The number of Catholics in the world is increasing and stands at present at 1.2 billion persons (Bomhoff and $\mathrm{Gu}$ 2012). The countries experiencing the greatest growth of Catholics are Asian and African countries, which are the principal focus for sustainable development efforts by governments and NGOs for the implementation of the UN Sustainable Development Goals (UN 2020). The demographic trends point to greater authority in the realm of sustainable development for the Church because the growth of the Church is principally located in developing countries. It is frequently stated in the sustainable development literature that those most affected by sustainable development programs should direct those programs or have meaningful input into their implementation for the good of their own communities and people (Stanton 2014; Cooper and Vargas 2005; Dodson and Smith 2004). Some national governments understand the implications of this growth and have contracted with numerous Catholic development agencies to achieve development goals, as well as to address refugee and migration crises in various places of the world. For example, the United States Conference of Catholic Bishops oversees American Catholic non-profit organizations who assist in this work and it was recently reported that the USCCB oversaw use of nearly \$1 billion from 2007 to 2016 for assisting migrants that have recently arrived in the United States (Hichborn 2017). This money is used by various non-profit organizations for migrant resettlement in the US as well as to fund migration relief efforts abroad, all of which fall under the umbrella 
of social sustainability, which among other issues is concerned with how societies deal with change and recognize the rights of persons who drive this change. Immigration is a major driving force for change in the developed world, and touches on the north/south divide," (Reese 2006; Massey and Zenteno 1999; Bourne 1999). While controversial, this support for migration is in keeping with Catholic Social Teaching and help illustrate the incredible influence the Catholic Church has on the United States government and with governments around the world, especially in the 'developing world,' given that relief agencies can exercise great influence on political institutions and leaders in affected countries when they bring development funds into poor countries (Fowler 2013).

At the most basic level, the power of the Catholic Church to influence sustainable development policy is encapsulated in soft power politics. Princen (1992) describes it best and is worth quoting directly:

Yes, the Vatican is unique on the stage of world politics. What distinguishes it, however, from nation states may, at the same time, put it in a small class of actors well adapted for mediating international conflicts. It obviously cannot punish states or threaten to do so. It cannot promise economic rewards for good behavior. But these very limitations, what would be liabilities in the game of geopolitics, can be assets in mediating a dispute. With no pretensions for world domination or geographic expansion, with no armies and only minimal liquid assets, with a time frame that encompasses years if not decades, and with no claim to democratic procedures and open government, the Vatican is uniquely suited to conduct negotiations of the most sensitive and intractable nature, (Princen 1992 pg. 149).

In other words, the teaching authority, if we want to frame it that way, of the Church is grounded in it having no measurable self-interest on the world stage. It has no claims to 
territory, aside from the tiny parcel of land the Holy See occupies, and has no ambitions for territorial gains, trade engagements, or complex issues of political intrigue. In short, the Church today can best be understood as having the potential to be the great center of diplomacy and human rights work on the international stage. This is possible through the network of the Church globally, in scope ranging from the local parishes to the dioceses to the non-profit organizations and universities that answer to some degree to the Church as an organization.

In other words, the Catholic Church still has a great deal of power in the modern world, and Pope Francis understands this, as is evident from the documents that emerged from the Amazon Synod in 2019 and 2020, as well as in the numerous UN conferences hosted at the Vatican in the past decade. The United Nations certainly recognizes the authority and power of the Catholic Church to influence policy and to promote sustainable development causes around the world. A December 2019 meeting between UN Secretary General Antonio Guterres and Pope Francis illustrates this point, with Guterres saying of the meeting and of the sustainable development message of Catholic Social Teaching, "These messages coincide with the core values of the United Nations Charter - namely to reaffirm the dignity and worth of the human person. To promote love of people and care for our planet. To uphold our common humanity and protect our common home. Our world needs that more than ever" (UN 2019). Thus, we see a recognition of power and authority of the Vatican by important global institutions.

But this is not a new phenomenon. In the aftermath of World War II, Pope Pius XII 
reorganized Catholic Action for the defense of European democracy against what the Church deemed to be Soviet totalitarianism (Pius XI 1937). Catholic Action will be covered in greater detail in the final chapter of this work, but it is worth noting now that Catholic Action is historically an organizing method of implementing Catholic Social Teaching by the laity, typically in opposition to both the ravages of socialism and capitalism, which the Church has stood against with equal force (Pius XI 1931). His predecessor, Pius XI, provided the best definition of Catholic Action that stands almost a century later:

It has been for us an exquisite satisfaction to see the Catholic Action organizations of all countries, both near and far, united round the common Father, inspired by a single spirit of faith, of filial sorrow and of generous impulses, all expressing their astonishment and grief in seeing Catholic Action societies persecuted and assailed here, in the very centre of the Apostolic Hierarchy, where its raison d'etre is strongest. Here in Italy, as in all parts of the world where Catholic Action exists, Catholic Action is true to its solemn and authentic definition. Obeying Our watchful and assiduous instructions (which you, Venerable Brethren, have so largely seconded), it does not wish to be nor can be anything other than 'the participation and the collaboration of the laity with the Apostolic Hierarchy.' (Pius XI 1931 a para. 5)

Catholic Action is but one form of organized lay action on behalf of the Church, best understood in conducting the social, political, economic, or, in the present, environmental work of the pope. In the pontificate of Francis, Catholic Action focused on the needs of the poor and most marginalized, especially in Italy. Francis met briefly with members of the youth arm of Catholic Action during Advent of 2017, where he reiterated one of the focuses of his pontificate.

In particular, he called on them to be attentive to those who are forgotten, to 'the poorest, the weakest, those relegated to the margins society 
because they are considered as a problem.' He told the children, 'These are your peripheries', and he encouraged them to seek out those who 'no one ever sees,' and to 'dare to take the first step to meet them, to give them a little bit of your time, a smile, an act of tenderness,' (Wells 2017).

Catholic Action is merely one example of Catholic Social Teaching in action, conducted at the direction of the hierarchy of the Church. These examples, however, demonstrate a level of power and authority the Church possesses to influence the secular world, both by claiming and demonstrating moral authority to act on behalf of the most marginalized members of society, but also in the influencing of secular politics. As stated earlier, the reorganization of Catholic Action to oppose the rise of communism in post-war Italy is an example from the modern day of the potential power a pope can have if he chooses to exercise it, when the mission of the Church requires that he act. Catholic Social Teaching is but one way of achieving the ends of the mission of the Church, when those goals intersect with the political world.

Sustainable development, by necessity, is deeply embedded in the political structure of both nation-states and the international community, which gives the pope a unique opportunity to exercise influence. The papacy has been embedded in political structures since the legalization of the Catholic faith in the Roman Empire in the $4^{\text {th }}$ century (Ray 1999, pg. 145-240). While this role has evolved over the millennia, the modern role of the pope in the international liberal order was best expressed by Pope Paul VI in his address to the United Nations in 1965, where he called upon the Church to work with world leaders to help facilitate peace and social justice (Paul VI 1965). Since that time, popes have used the considerable influence they possess with the world's Catholics and with the non- 
Catholic leaders of the world to help facilitate efforts towards attaining peace and justice, including the contemporary push for sustainable development by Pope Francis. It is against this backdrop that Catholic Social Teaching as a resource for policy makers must be understood, as well as the potential as a great ally the Church has for those who seek to establish a more sustainable economy and socially just order.

Having explored the historic claims of the Catholic Church and the tangible authority the Church has on the world stage of politics and economics, the question of what Catholic Social Teaching is must be addressed. In Christian terms, Catholic Social Teaching represents the application of the commandment to "love thy neighbor" (Mark 12:31) explored in sociopolitical and economic terms that has been developed into a body of principles, which has itself given birth to various Catholic movements in history. According to DeBerri and Hug, "this body of principles, guidelines, and applications has developed in a rich fashion. It provides a compelling challenge for responsible Christian living today" (2003, pg. xi). Catholic Social Teaching can be defined for present purposes as the application of the Catholic faith and the implication of the Gospels into social, political, and economic principles (Esolen 2012 pp. 6-11). The body of work is rooted in the work of St. Thomas Aquinas in the $13^{\text {th }}$ century and Br. Luigi Taparelli writing in the mid-1 $9^{\text {th }}$ century (Burke 2010). The principal body of literature came into focus in the late $19^{\text {th }}$ century and continues today starting with Pope Leo XIII and continuing through Pope Francis (Schwindt 2015). Writing on the influence of Pope Leo XIII, CST scholar Anthony Esolen (2012a) describes the role of faith in CST: 
His [Pope Leo XIII] thoughts prescind not from the nature of the spanking new modern state, nor from social advances sometimes more apparent than real, but from the changeless nature of man, discoverable both by reason and by humble attention to the revealed word of God. Leo never supposed that one could devise any Social Teaching without understanding what a society is to begin with, which requires that we understand what human beings are, and why they are - for what end God made them, male and female, in His image and likeness. Leo surveys the world from the mountaintop of the faith-not from the mercurial ingenuity of a vain scholar, or the meddlesome pride of an innovator (para.2).

Thus, Catholic Social Teaching largely focuses on principles rather than specific policy proposals, framed in terms of the question of what makes a person a person. The concerns of the Church are and always have been the development of virtuous persons, which is the ultimate end of CST. Thus, these principles are what will determine the compatibility of the teachings of the Catholic Church and the body of work derived from it with secular sustainable development initiatives.

Catholic Social Teaching is a body of literature that has been applied to real policy and program scenarios in the $20^{\text {th }}$ century. It is the writings of various popes, bishops of the Church, lay scholars, and social commentators. As Pope John Paul II wrote, "[the Social Teachings of the Church] builds up gradually, as the Church, in the fullness of the word revealed by Christ Jesus and with the assistance of the Holy Spirit, reads events as they unfold in the course of history. She thus seeks to lead people to respond, with the support also of rational reflection and the human sciences, to their vocation as responsible builders of earthly society," (1992, pg. 395). Thus, the purpose of Catholic Social Teaching is to provide the tools necessary for everyday laypersons to work towards a more just society, but not typically to offer specific policy programs with implementation strategies for 
achieving the goals of states or non-profit organizations.

The purpose of Catholic Social Teaching is to promote a virtuous society that enables families to flourish and spiritual growth to be possible for the members of society. This requires a harmonious relationship between the interwoven spheres of family life, the sociopolitical, and the Church. These are all essentially involuntary associations, for just as we are born into families thus are we born into cultures, as well as into the Church. These writings were developed over the centuries and regained new focus under Leo XIII, with the aforementioned roots in Thomistic theology and the Gospels (Esolen 2012 pg. 11).

The social teaching tradition of the Church is focused on the question of social justice and order. Justice requires the recognition of human dignity, which is only achievable through Christian love (Bishops 1971) and the restoration of Christianity as the foundation of a stable society (McCall 2011; Pius XI 1922). This is explored in greater detail in the subsequent chapters on social and political sustainability. But, for now, it must be understood that sustainability is understood in terms of social justice (Jenkins 2013; Dobson 2003; Dobson 1999). Some theorists, such as Dobson (2003) have recognized that there is a potential for conflict between sustainable development as it is seen in practice and social justice. This is where the social teaching of the Church is helpful, as the Church recognizes that all questions are social questions (Esolen 2014). It is a basic tenet of the social sciences that at their core, all issues are social issues in nature, subject to the dynamics of agenda setting and issue construction (Hannigan 1995; Kingdon 1984). Catholic Social Teaching is in no way different in this regard; it is subject to the same 
pressures of issue construction and agenda setting as secular forces in the political realm traditionally have been. This is in part due to Berger's observation from the sociology of religions that "real world" events are often translated into the religious experiences of believers and then turned into action embedded with meaning (Berger 1969). This process aids in institutionalization among the faithful, with the faithful adopting at least in part the social teaching of the Church as part of the reference point for interactions in everyday life (Berger and Luckmann 1966). The application of Catholic Social Teaching in countries with a large Catholic population can aid in achieving development goals in this way if the programs are properly designed and presented to those affected.

The word "social" is essential to understanding CST. The Catholic Church understands human nature as highly social, and, in the context of her social teaching, is concerned with people living lives of virtue (Storck 2016). Esolen explains that the virtues are simple enough to understand in their context: "The Thomistic understanding of virtue is straightforward enough. A virtue is a habit, what Aristotle calls a second nature. It is difficult to attain — hence, its association with adult masculinity, which is what the Latin virtus literally means. It involves the perfection of a faculty, like the deep knowledge in the hands of a master craftsman. Therefore, its definition cannot be arbitrary; it is bound up with the faculty in question, and the work to be done," (Esolen 2014). Thus, the theological and moral virtues in individuals support the development and sustaining of a virtuous and just society, as they call upon the individual to sacrifice the needs and wants of the self to promote the greater good of others. The principal cardinal virtue that is of concern here is that of justice, which the Catechism defines as "a constant and firm will to 
give their due to God and neighbor," (C Church 1807; Aquinas II-II q58). This, like all other issues touching on morality, requires a sense of morality and personal conscience that are right-ordered and in keeping with the unchanging moral teaching of the Church. Without this right-ordered morality, true justice is impossible, for justice cannot exist without virtue (MacIntyre 1981).

The tradition of Catholic Social Teaching gave rise to various schools of thought promoted by clergy and the laity, most notably Distributism, which sought to correct the ills caused by industrial society that lead (in their estimation) to centralization of property and dehumanization of persons under either capitalism or socialism. Early theorists such as Fr. Vincent McNabb, G.K. Chesterton, Fr. Heinrich Pesch, and Hilaire Belloc promoted a vision of the world that on the one hand almost romanticized agrarian life while, on the other, focusing on the ills of urbanization and suburbanization. McNabb, in his landmark essay Nazareth or Social Chaos defined the city as the proximate occasion for sin and called vociferously for a back-to-the-land movement that had wide-ranging influence in the U.K. and United States in the 1920s and 1930s (Bruce 2009, in McNabb 2009). Historically the Church has thrived in rural environments that McNabb and others state promote heroic virtue, whereas the urban environment undermines traditional morals and family arrangements. This concern is clearly on display in Chesterton when he states, "the modern city is ugly not because it is a city but because it is not enough of a city, because it is a jungle, because it is confused and anarchic, and surging with selfish and materialistic energies," (Chesterton 1901). Cities, like the virtues, ought to be places of order and law, and fail to promote heroic virtue in that they are often places of vice, chaos, and moral 
degradation.

The early Distributists saw a return to agrarian life as a Gospel-inspired return to social sanity. McNabb observed a key understanding of the relationship between humans and the land that those engaged in the work of sustainable development must address when he stated that Christ chose to incarnate into a life of labor, so as to not disrupt the work that the Father imposed upon Adam and Eve. This may appear to be a theological point, but at the core of Catholic Social Teaching is the concept of human dignity, and labor is central to that notion (Leo XIII 1889). McNabb's observation goes further, with the Incarnation occurring also in a family unit, which emphasizes the core element of Catholic Social Teaching that the family is the cornerstone of society (Leo XIII 1889; John Paul II 1989). An often overlooked aspect directly related to this is the complexity of modern, postindustrial society that has ravaged the family unit, which led Chesterton, McNabb and the rest to call for a return to a more simple social and economic order (Chesterton 1910).

This sentiment is echoed by the controversial historian and polemicist Hilaire Belloc, who decried the increasing complexity of industrialization and urbanization. "Things will not get right again...until society becomes as simple as it used to be, and we shall have to go through a pretty bad time before we get back to that" (Belloc 2004, 163). The authors of the social teaching of the Church, be they popes, bishops, or laity, all repeat this claim. Thus, we see John Paul II calling industrial and urban life disordered to such an extent that the elderly and the infirm are set outside the view of society (John Paul II, 1981). Urban life is disordered because people are called to love their neighbor, not to embrace a 
form of relativism that calls on us to ignore our neighbor's needs. An essential element of Christian virtue is that the evidence of the relationship with Jesus Christ each Christian has is in the way the individual Christian cares for his neighbor (Pope Francis 2015). This is the principle of Christian stewardship, which requires that the individual Christian recognize that the gifts of God are not given solely for the benefit of the individual but are to be put at the service of the Church in the building of the Christian society, which is one of justice, solidarity, subsidiarity, and peace (Evans 2006). Catholic Social Teaching, if it is of any value to the international community of non-profit organizations and developers, is a call to return to simplicity. As stated earlier, in addition to the theological and spiritual call presented in Catholic Social Teaching, the call of the popes and teachers of the Church is to return control of development and political structures to as local authority as is possible (Chesterton 1926; Pius XI 1931; Belloc 1937).

\section{A Brief History of CST}

To better understand what Catholic Social Teaching is, a brief look at its history is worthwhile. Earlier I stated the origins of Catholic Social Teaching are rooted in the writings of late $19^{\text {th }}$ century pontiffs inspired by Brother Luigi Taparelli. While this is true, the roots of CST go further back in the scholastic history of the Catholic Church. The earliest commentary on social life by major church figures was by St. Augustine in The City of God. Augustine was a $5^{\text {th }}$ century priest and bishop in the Catholic Church who, in City, described society as a war between the followers of Christ and the followers of the 
devil. This spiritual war includes those states, tribes, and nations allied with the Church and those called pagan (Augustine $2012 \mathrm{pp} 2-40$ ). The social focus of the Church was in nakedly spiritual terms and paid little attention to the political concerns of the day, due in part to the assumption that if political leaders pursued Christian virtue then the rest would flow from there; the Christian ideal, as it was understood, called for leaving behind all earthly pleasures, suggesting that politics was something crude or even vulgar.

Inspired by Aristotle and Plato, as well as St. Augustine, St. Thomas Aquinas would approach the question of the social life of Christians differently than Augustine. Aquinas, writing in the $13^{\text {th }}$ century, spent little time on social questions and instead focused principally on questions relating to theology, philosophy, and the liturgy. Yet Aquinas would influence the future work of pontiffs and the laity in profound ways in his Summa Theologia and elsewhere in his Commentaries on Aristotle's Politics. Aquinas's intellectual focus was on the common good and the promotion of the Kingdom of Christ in the earthly realm. Thus, for Aquinas, Christianity did not involve specific requirements for conducting civil society. The prevailing notion of Aquinas's day amongst Christian thinkers was that the people should "render unto Caesar the things that are Caesar's" (Matthew 22:21), which meant in the context of politics that Christianity can flourish in any political regime with the caveat that the believers be permitted to "render unto God the things that are God's," which in practice for the layperson means being permitted to live and exercise their faith without fear of reprisal or persecution from the state (Aquinas 1911). This is reinforced by Christ's claim to be King whose kingdom was not of this world (John 18), which led St. Paul to repeatedly exhort his readers to obey the civil authorities. 
Aquinas's contribution to Catholic Social Teaching that persists to this day is his work on the Natural Law, justice and the basis for morality. It was in Aquinas's often overlooked work de Regno that the Doctor of the Church would offer the foundational work of Catholic Social Teaching. In that work. Aquinas, in writing to the king of Cyprus, explains the correct ordering of society as being centered on the family as the priority unit, who have special duties to the Church and to obey secular authority (Aquinas 1949 q. 104). This, along with the rest of the work, would become the foundation of much of the social teaching of the Church for Leo XIII, as he would attempt to bring the lessons of Aquinas into the modern world to address the issues wrought by an industrial society that was experiencing a conflict between an almost wholly unregulated capitalism and an ascendant socialism (Behr 2005).

This body of work that was begun by Pope Leo XIII with Rerum Novarum (1891) and Immortale Dei (1885) would be built on both the work of Aquinas and the work of some of his predecessors, such as Pius IX (1846-1878), Pius VIII (1829-1830), and Gregory XVI (1831-1846), who wrote on issues such as usury, liberalism and the emerging western world order that was born from the enlightenment. Leo XIII's work, along with that of his successors through the present age was focused on providing the answers the Church can provide to social questions that, especially in the years after World War II, the international liberal order would address. The Church's body of work from the past two centuries remains relevant to address contemporary issues of governance, environmental trauma, post-war reconstruction, economics, and virtually any other social problem, with a unique focus on the family as the central building block of society. 
The Catholic Church does not intend to limit the Gospel-based message of building a just, sustainable society to the Catholics of the world. Rather, "the Church continues to speak to all people and all nations," as the Compendium Of The Social Doctrine Of The Church says, with the goal of educating the people of the world on "the realities of the economy and labor, of technology and communications, of society and politics, of the international community and the relations among cultures and peoples" (PCJP 2009). The question of why non-Catholics should pay attention to the opinions of the Catholic Church will be addressed shortly. For now, it is sufficient to say that the Church sees as its mission to promote the virtuous, sustainable, just society to all peoples. This mission is inseparable from The Great Commission, which is spreading the Gospel of Jesus Christ to all nations (Matthew 28:16-20). This is not to suggest that the Social Teaching of the Catholic Church is communicated in the world in order to promote the Great Commission or to impose theocracy, as some might suggest (Slade 2019). There is a debate on the merits of the Church involving itself in secular governance issues, but the substance of that debate is irrelevant to the discussion at hand. ${ }^{2}$

Before answering the question of why a Catholic approach to sustainable development is important for secular governments and non-profit organizations, the essential core principal of Catholic Social Teaching should be addressed: the preferential option for the poor. This phrase came from the post-Vatican II era of Catholic Social

\footnotetext{
${ }^{2}$ For those who find this discussion to be of interest, see John Zmirak's "The Myth of Catholic Social Teaching" (2014), Jayabalan's “Letter From Rome" written on behalf of the Acton Institute (2011), or Gilder (1996) "The Soul of Silicon," all of which challenge implicitly or explicitly the papal authority to teach on economics and politics.
} 
Teaching but is firmly rooted in the concerns for the working class and alleviating poverty as expressed in Rerum Novarum (Leo XIII 1891, para. 23). While the plight of the poor has been a special focus for Catholic Social Teaching since the papacy of Paul VI (19621977), Leo XIII included a focus on the duties of the rich and broader society to the poor in Rerum Novarum, which he described (1889, para.37) in the following terms:

still, when there is a question of defending the rights of individuals, the poor and badly off have a claim to especial consideration. The richer class have many ways of shielding themselves, and stand less in need of help from the State; whereas the mass of the poor have no resources of their own to fall back upon, and must chiefly depend upon the assistance of the State.

For many policy designers or non-profit organizers working in the field of sustainable development, a driving force is the alleviation of poverty in a world with growing gap between the rich and the poor (Asadi, Akbari, Fami, Iravani, Rostami, and Sadati 2008; Glasmeir and Farrigan 2003). In recent years media reports have shown that efforts by sustainable development organizations have often failed to alleviate poverty through implementation of programs explicitly for that purpose, and at times exacerbate poverty in developing countries (O'Grady 2018; Brand 2012).

Thus, the purpose of Catholic Social Teaching should be understood as providing principles and guidelines for Catholic efforts to alleviate unnecessary poverty, be they policy programs or activities of simple voluntary associations of the laity in action. Catholic Social Teaching provides guidance for statecraft but is not intended for statecraft itself. The Church opposed the Westphalian political order but eventually came to work 
within it through a broad call for Catholics to participate in politics while adhering to Catholic principles. While historically the Church has favored some form of monarchy, in the contemporary era the Church has always sought to work with regimes of all sorts with the purpose of providing guidance to create a society that is more just and ordered towards the natural law (Philpott 2000; Leo XIII 1885). An important underlying principle that will guide this dissertation is that the Church through her social teaching tradition tries to guide society away from a purely materialistic orientation and eschews any ideology that lends itself to purely materialistic concerns. This is, as we will see, the core of the condemnation of socialism and capitalism that the Church teaches, as an erroneous ontological focus for policymakers can lead to "a form of social organization which aims solely at production; it places too severe a restraint on human liberty, at the same time flouting the true notion of social authority," (John XXIII 1961, n. 34). John XXIII said this to describe socialism, but the same condemnation of unregulated capitalism and consumerist culture more broadly is echoed by popes ranging from Leo XIII to Francis today.

This observation is echoed in the contributions to the development literature of some policy planners and theorists. As Raco (2005) states of the underlying driving values of the cold war and immediate post-cold war era of development, these programs are often materialist in nature, as researchers have noted that "the relationships between states and citizens have documented the rise of rolled-out neoliberalism. Development agendas are, it is argued, increasingly dominated by the principles of market-driven reforms, social inequality, and a drive towards enhancing the economic competitiveness of the supply side of the economy" (Raco 2005 p. 324). In the terminology of Pope Francis, this is a consumer 
culture that is often inflicted upon indigenous cultures and under-developed societies to bring those societies and cultures into the broader consuming world (Francis 2020). The Church understands human thriving as something more than that, and there is a harmony assumed in Catholic Social Teaching that envisions a more sustainable society as being more in tune with the needs of the family and in a society built on strong communities in a healthy natural environment. The sustainability literature is divided between camps from various schools of thought including economics and business, ecological management, and natural resource management that can be broadly considered in keeping with the anthropocentric tradition in the first, and in the second groups rooted in the deep ecology and biocentrism schools of thought that seek a greater recognition of the value of the natural world without human needs being the main factor in the value determination (Jackson 2006; Robinson 2004; Jacob 1994). A noteworthy amount of the literature is concerned with this materialist approach and is clearly seeking alternative options that are commensurate with the approach offered by the Catholic Church (Hui 2008; Doherty and Ndemo 2006). One such alternative is the transformation of the economy from consumerist to one that promotes sustainable consumption that is closer in keeping with the direction Catholic Social Teaching is taking under Pope Francis (Kotler 2019).The work of the popes since Leo XIII provide the intellectual basis for the Church providing guidance and even teaching to the secular and Catholic world for sustainable development work. However, there are more concrete reasons to take the Church's position seriously, and it is to those reasons that I turn next. The papal encyclicals and the work of lay scholars are not intended to be relegated to the realm of the purely theoretical, which is what has been my focus thus 
far. Chesterton once quipped that the test of a good philosophy was whether you could take examples of it from the concrete world, and thus it is to where the theory meets the world of practice that I turn to next.

\section{Why A Catholic Answer to The Sustainability Question?}

The proposal to use Catholic Social Teaching as an alternative means of achieving shared sustainable development goals requires justification. The simple answer can be provided by the retired US Cardinal Donald Wuerl, who stated that a Christian life is dutybound to the Creator, including the keeping of His commandments. Wuerl argues that the challenge the world faces today is the separation of faith from social problems. Cardinal Wuerl describes this situation in his pamphlet for parish ministers The New Evangelization when he states, "The context of our proclamation is the highly secular view of life in our culture that bleaches out recognition and appreciation of God and religious faith" (Wuerl 2013, p 21). Traditional discourse on sustainability frequently ignores the claims, world view, and lived experiences of those who adhere to a religious way of life (Ives, Abson, von Wehrden, Dorninger, Klaniecki, and Fischer 2018). The Catholic approach will assume the interests of the faithful are essential to achieving a sustainable and just society, and in so doing will seek to open a channel of dialogue to finding solutions to shared problems in the environmental, social, and political spheres.

But what do these solutions look like in practice? Often these solutions involve Catholic organizations accepting contracts from national governments and working with 
local organizations for implementation of programs that fit or at least do not conflict overtly with the mission of the Catholic Church. An example is the Catholic Campaign for Human Development (CCHD), which in FY2014-2015 distributed \$330,000 USD in federal grant aid to local agencies in the United States for community development and other works that would fit broadly under the rubrics of social sustainability (Lepanto 2020). Numerous Catholic organizations in the US and around the world partner with various governments to achieve development goals, and often these programs raise concerns among the faithful and among the bishops of the Church when conflict arises, pointing to the necessity for policymakers to understand what Catholic Social Teaching is and what the implications for program development are when partnering with such organizations. These concerns involve the conflict between the Catholic Church's stance against abortion, contraception, and other measures the Church associates with population control that are frequently cited by Catholic watchdog groups as being included in development programs promoted by the United Nations and development NGOs (Hichborn 2017). Proponents of these programs state that these approaches are focused on women's rights and elevating the impoverished out of abject poverty (Bernstein and Jones 2019). This difference is in moral terms highlights a profound divide between the Church and some approaches to sustainable development that illustrate the need for a greater understanding of CST. A familiarity with the moral dimensions of CST can help avoid conflicts and roadblocks for those engaged in the work of development in the effected countries.

Another lay organization engaged in the work of social sustainability in the US is Catholic Relief Services (CRS), which partners with numerous purely secular 
organizations to promote the causes of social justice and community development. In 2013, CRS distributed \$64 million USD to various partner organizations in the United States promoting this work, though not without controversy, as these organizations often had to either abandon Catholic principles or ignored them entirely in order to fulfill the duties required in receiving federal grant aid funding (Lepanto 2013). The conflict within organizations like CRS and others illustrates the tendency in the administrative theory and behavior literature that demonstrates the conflict that can occur within organizations when external programing funds conflict with organizational mission and values (AlvarezGonzalez 2017; Dolnicar 2008; Frumkin 2000). It is one of the aims of this work to provide these organizations with resources and assistance in developing a better understanding of Catholic Social Teaching to inspire fruitful partnerships that find solutions to existing social problems.

Despite these controversies, Catholic Relief Services and the Catholic Campaign for Human Development have a strong record of providing refugee and migrant resettlement assistance, homeless funding, and support for organizations doing related work that these organizations believe supports the work of the Church. An example of this is CRS's Ugandan Apprenticeship program (CRS 2020), which is designed to support economic development activity in Uganda, as well as the Sustainable Outcomes for Children and Youth (SOCY) project in Uganda (2017), which promoted nutrition education for families. These programs, often done in partnership with outside organizations like USAID, illustrate the influence of CST in the application of aid programs in practice. 
More space will be dedicated to other organizations engaged in implementing Catholic Social Teaching in Chapter Seven. Those organizations will represent for-profit organizations, not-for-profit environmental activists, and other groups that have a history of successfully implementing the social teaching of the Church in the world of practice. In some cases, those organizations have had great success despite receiving little to no external funding. The implementation of Catholic Social Teaching has both success stories and stories that illustrate a failure to uphold the trust of those most invested in those organizations success: namely Catholics, who often supplement federal funding with private giving.

\section{Looking Ahead}

Catholicism is not a political ideology. To confuse Catholic Social Teaching with an ideology or to attempt to attach the faith or the Church's social teaching to a secular ideology is to commit a grave error. Catholic Social Teaching is what the Magisterium and the lay intellectuals state a society that is aligned with the Gospel would look like. It is worth noting here that CST is largely free of explicating policy proposals, though Laudato $S i$ was a departure from this in many regards; instead, the social teaching of the Church represents ideals and principles that should guide action, or values that should underscore programs by policymakers, organizations, and most importantly, everyday Catholics. It is with that frame in mind, the everyday Catholic and policymakers, that the following chapters proceed. To that end, the next chapter will focus on what the Church teaches about 
what is often called "social sustainability" (Jacques 2014; Littig and Griessler 2006), beginning with the individual person, the family, and human nature. From there this dissertation will continue to unfold. Catholic Social Teaching is a reaction to the needs of the world, and especially to the attempts of the world to address these needs in a way that leaves Christ out of the solution (Francis 2015), for Christ is essential to understanding Catholic Social Teaching, although adopting the religious belief in Christ is not necessary for CST to be of use to sustainability practitioners.

The words of John Paul II are instructive for framing the discussion in future chapters. In a Sollicitudo Rei Socialis, Pope John Paul II (1977-2005) made a statement that is relevant to the discussion of Catholic Social Teaching and sustainable development, that demonstrates the limits of the Church's role in these matters. "For the Church does not propose economic and political systems and programs, nor does she show preference for one or the other, provided that human dignity is properly respected and promoted, and provided that she herself is allowed the room she needs to exercise her ministry in the world" (emphasis added) (41). That is highly significant. A controversial point for scholars, commentators, and even those who seek to implement Catholic Social Teaching is the Church's relationship with capitalism and socialism, which will be addressed in future chapters. The statement of John Paul II presents the modern justification for the Church's taking a clearly oppositional viewpoint to both liberal capitalism and Marxian socialism from the earliest days of Catholic Social Teaching through Rerum Novarum (1891) and even today. The varieties of capitalism seen in the world today are seen as violating human dignity, while socialism is seen by the Church as violating both human dignity and the right 
of the Church to preach the Gospel.

For the policymaker, then, the social teaching of the Church can be understood as a sort of third way of understanding sustainable development. It does not favor liberalism and neoliberalism, nor does the Church favor socialism. This has ramifications for the implementation of policy and policy design that many organizations may not be prepared to address. The purpose of the following chapters will be to outline the principles of Catholic Social Teaching so those doing this work, be they Catholic organizations or secular ones, can be better equipped to deal with the concerns of the Catholic peoples they encounter, as well as to provide a different way of doing the important work of development than has been tried on a large scale before.

Scholarly work on the issue of sustainable development program implementation at the local level of governance is nothing new. A landmark study by Sabatier and Davis (1980) found that national governments often use development aid to force local governments to comply with federal and national policies regardless of cultural conflict (Sabatier and Davis 1980). If "[s]ocial sustainability is a life-enhancing condition within communities, and a process within communities that can achieve that condition" (McKenzie 2004 pp. 3), then undue interference from outside forces can harm the social fabric of these communities. These tendencies can be understood as a violation of the Decentralization Principle (Cooper and Vargas 2008) that some policy designers concerned with community development have embraced. is there a path forward for sustainable development and policy implementation that supports the rights of local communities while 
achieving the goal of creating more sustainable communities and economies? Catholic Social Teaching does provide answers to the concern of respecting local communities and the autonomy of persons in the pursuit of sustainable development goals and programs. It is to the issue of social sustainability that the next chapter is dedicated. 


\section{Chapter 3 Social Sustainability}

\section{The Person and the Family}

"Freedom does not mean that right to do whatever we please, but rather to do as we ought. The right to do whatever we please reduces freedom to a physical power and forgets that freedom is a moral power." -Fulton Sheen (1945)

"Every major question in history is a religious question. It has more effect in molding life than nationalism or a common language." --Hilaire Belloc (1905)

Sustainable development is an issue of human flourishing. The UN sustainable development goals are anthropocentric in nature and are often criticized as such (Kotze and French 2018). While the Catholic view is one that will appear anthropocentric to the outsider observer, the teaching of the Church is that the proper understanding of humankind is the human integrated in a relationship with God. To understand this relationship and the implications that relationship has for the natural world and sustainable development, I begin with what the Church teaches about the human person. How the Church views human nature is critical to understanding what the Church teaches on sustainable development.

\section{What is The Human Person?}

The Church has taught, since the first centuries, that human beings are created in the image and likeness of God, for God (Esolen 2014). The nature of the creation of 
humanity is best understood as the person being the union of matter and spirit (or body and soul) (Aquinas 1911 q. 2). Humans possesses dignity beyond that of the rest of Creation. These theological principles have profound implications for Church teachings on the nature of society, the relationship of persons, the individual, and the arrangement of society and its use of natural resources.

In this chapter the concepts of individuality and human dignity will be explored. Justice cannot be understood without a clear understanding of human dignity, the person, and what rights might emerge. These are first principles, which must be understood because without understanding what the first principles are then what is built on them will be built on false ground. That is, it will be built on folly. These spiritual principles help to frame the landscape that any policy innovator will operate.

\section{Humanity and the Individual}

Individualism is typically understood in its political context. While this will be explored, individualism is a broad tapestry of ideas ranging a great many contexts. The chief recognized forms of individualism are religious, ethical, and political. Each will be briefly examined in turn in order to provide what the Church teaches about the individual, for how we and outsiders broadly understand individualism touches on issues of liberty, sovereignty, and the boundaries of power and justice.

The freedom of the individual to find God and to think for themselves in matters of religion are of utmost importance. The Church has taught that the individual cannot be 
coerced into religious belief, despite the history of many Christians and adherents of other religions not understanding this, including some working on behalf of the Church. As the Catechism states, "Freedom is exercised in relationships between human beings. Every human person, created in the image of God, has the natural right to be recognized as a free and responsible being. All owe to each other this duty of respect. The right to the exercise of freedom, especially in moral and religious matters, is an inalienable requirement of the dignity of the human person. This right must be recognized and protected by civil authority within the limits of the common good and public order," (C Church 1738). The Second Vatican Council declared, in Dignitatis Humanae, that persons are to be free of coercion on matters concerning worship and belief by virtue of human dignity (Paul VI 1965).

This initial focus on religious liberty brings to focus the essential issue: human dignity. Esolen (2015, para. 7) described human dignity as:

the reverence that it rightly demands - springs from the reality of the human person, created in the image and likeness of God. Reality, not fantasy, not social convention. When Jefferson wrote that certain rights were "inalienable," using the term in its most precise signification, he meant that even we cannot divest ourselves of them. We have those rights whether we like them or not. Therefore, there is a givenness in man; he is at the least the sort of creature who possesses rights which he cannot sign away, or wish away. He may recognize them and honor them. He cannot annihilate them because he has not created them to begin with." Human dignity is essential to the understanding Catholics have of humanity and its relationship with everything in our environment and is inseparable from moral theology.

The individual possesses human dignity by virtue of his being created in the image and likeness of God. The theological underpinning of this can be understood that human beings are free because they are imbued with free will; human dignity is then understood 
as originating from the gift of free will and the understanding of the person as a creation understood in the aforementioned terms. Human dignity is understood in the terms of inherent freedom originating in free will (Schindler 2013). It is the divine origin of the person, designed for freedom, and aligned towards freedom in the soul of humans that points to not only human dignity but what separates human beings from other creatures. For it is humanity's ability to overcome merely natural instinct and desire by virtue of this freedom that points to human dignity. The individual human possesses dignity in order to pursue transcendent truth, and it is to this purpose that society is to be ordered. Any social order that prohibits human beings from pursuing transcendent truth and individual maximization is inherently unjust.

Human dignity is a critical intersection point for those engaged in the work of sustainable development. The question of what responsibilities current generations have to future generations is one that is debated in the theoretical literature (Duwall 2014). In the secular literature the criticism of sustainable development is readily seen in the form of criticisms of the concept of development as a human-centered program that is inherently anthropocentric in its framing (Kopnina 2014; Estes 2010). An example of this critique and the rejection of it is seen in Ganowicz-Bączyk (2016), where the critique of sustainable development being deeply anthropocentric is presented due to its being primarily concerned with natural resource use, agriculture, and human flourishing, as well as a viable alternative that is in keeping with CST:

From the very beginning, this idea has referred to human usage of natural resources, therefore, one can certainly speak of its fundamentally 
anthropocentric character. The principle of sustainable development assumes protection of nature merely for the sake of people and not for nature itself. Putting aside any anthropocentrism-biocentrism-ecocentrism controversies, one should admit that this is not an unjustified, groundless effort. On the contrary, it is reasonable in the sense that, if one demands from humans some wide-ranging and far-reaching restrictions and retardation of their activity and interest, one should also take into account their needs as rational beings -entities capable of such self-limitations and oriented on a comprehensive, multidimensional personal (physical, psychical and spiritual) development.

The anthropocentric position doesn't always consider demands of human dignity and their spiritual dimension, as Ganowicz-Bączyk illustrates here with her critique of the debate between the anthropocentric and biocentric positions.

Human dignity comes at the cost of responsibility. The American Catholic nonprofit organization, Serviam, describes Catholic Social Teaching as "not [a] justification for ever-increasing expenditures on a nation's welfare state. Conversely, it stresses the personal responsibility of mini societies (i.e., families) comprised of a husband and wife, raising their children wherein each member has immeasurable dignity and value"(Serviam 2017). While government social programs are permitted and even endorsed by the Church (USCCB 2016), government action is not a substitute for the responsibility of individuals to act in defense of human dignity. Human beings have a duty to act consistent with their free will, as will be demonstrated when the subject of stewardship is explored.

The individual is best understood in context to others: to other individuals, to the society at large, and to their family. Human beings do not exist in isolation, nor do they flourish and achieve their maximum potential in isolation from one another. The 
importance of the social nature of people is recognized in various fields of inquiry. For example, the Public Administration literature recognizes that social networks and the associations employees identify with outside of the field of work is important to employee retention (Wright and Pandey 2008; Moynihan and Pandey 2008; Perry and Wise 1990). This is recognized in the sustainability literature as well, in numerous areas of concern including in the examination of urban conditions and the implications those conditions have for development and ecology (Van den Berg, Hartig, and Staats 2007). This subject is broad, but one intersection with CST is the recognition of the dignity of people and the failures of contemporary social arrangements, such as in the work of Diesendorf (2000), where the author cites income inequality and failures of the criminal justice systems as signs of failures of the social dimension of sustainability and the implications of that for environmental policy. The literature often presents this in purely materialistic terms that either reinforces a sort of embedded individualism or collectivism, with little attention given to the family. An example of this conflict is seen in Cho (2013), which examined the different approaches taken to addressing development issues in collectivist societies compared to those in societies that emphasized the individual. The Catholic Church presents a different view. The social teaching of the Church does not fetishize the individual or the collective; rather, the perspective of the Church presents an ontology for those who understand that humanity exists in relationship with other human beings but possesses dignity as individuals (Bevans and Gross 2009; Paul VI 1965).

As individualism as a political value characterizes the values of the capitalist West, this is of special concern to those engaged in the work of sustainable development, even if 
those workers are not aware of the role of individualism in the materialist culture. The fetishization of the individual in liberal cultures loses sight of human dignity through the process of atomization, replacing human dignity with the primacy of the ego, which has been argued is a byproduct of the Protestant Reformation (Fisher 2013, pg. 62). John Paul II stated in 1997:

Individualism presupposes a use of freedom in which the subject does what he wants, in which he himself is the one to "establish the truth" of whatever he finds pleasing or useful. He does not tolerate the fact that someone else "wants" or demands something from him in the name of an objective truth. He does not want to "give" to another on the basis of truth; he does not want to become a "sincere gift." Individualism thus remains egocentric and selfish, $(2015,136)$.

The Church grounds its social teaching in theology because the Church makes claims of objective moral truth, which serves many purposes including to ground the individual in the context of a religious environment that makes demands on the behavior of the individual, regardless of what the perceived rights of the individual may be. It is in ignoring these rights that we see the wisdom of Chesterton's observation that "individualism kills the individual"(Chesterton 1928) because the true flourishing of the individual comes in the recognition of their duties to others and fulfilling those duties. The needs of others come before the needs of the individual, which only has meaning when it is understood and lived out voluntarily.

Rights, in the Catholic tradition, come with duties, which reflect the Aristotelian influence on Catholic Social Teaching. The Church teaches that the person is of incomparable and inviolable worth due to being created in the image and likeness of God 
(Tilson 2014; Catholic Church 2004). On this matter the individualists, especially in America and Western Europe, would agree, to such an extent that many policy claims based in this approach emerge in the secular world (Mattson and Clark 2011; Stetson 1998). The Church makes further demands, however, beginning with the right to life. As John Paul II stated, the rights of the individual are an illusion if this isn't rooted in a recognition that life itself is sacred and inviolable (JPII 1988). Human beings, in the Catholic understanding, are required to respect other persons with 'maximum determination' (ibid), for other rights are incomprehensible if they are not rooted in a right to life. It is because of this that many expressions of Catholic Social Teaching often include pacifism or an absolute rejection of warfare, though the Church has categorically rejected both ideas (and was indeed one of the main developers of Just War Theory).

This concept is reflected in Pope Francis's understanding of subsidiarity, termed in Chapter 1 as a kind of positive subsidiarity. This conception of subsidiarity states that higher levels of authority are obligated to respond to troubling and complex social conditions as competencies and resources dictate. The overriding concern is human dignity and the Common Good. The condition of human beings and the natural environment cannot be subjected to or limited by concerns for power in the abstract (Francis 2015, 178-179). There is a proper place for governments, organizations at the meso level, and supranational governments to intervene in local decision-making and resource management when the Common Good is under threat due to complexity in decision making. The duties humans have to one another and to the environment are not limited to those near one another. Governments have a God-given duty to govern for the Common Good (Aquinas 1949). 
The Church is less concerned with the rights of individuals or groups than it is with the duties of persons. Scripture commands human beings to love their neighbor as themself (Mark 12:33). "It is not possible to love one's neighbor as oneself and to persevere in this conduct without the firm and constant determination to work for the good of all people and of each person, because we are all really responsible for everyone," (JPII, SRS, 1998, pp565-566). Every person has some responsibility to persons everywhere, both near and far, making the commandment 'love thy neighbor' have real weight in a globalized world.

But there are limits. In all things related to Catholic Social Teaching the question must be asked 'to what limits?' The limitation is good conscience. For example, the Church states that abortion is always intrinsically evil, full stop. But on issues related to immigration, environmental regulation, taxation, and others that are not viewed as intrinsically evil the Church merely provides guidance on making moral decisions. As Michael Davis (2017), the US editor for the Catholic Herald, describes in an article in Crisis Magazine, Catholics have a 'divine mandate' to engage thoughtfully with the social teaching of the Church to transform society.

CST frames the discussion of limitations in the language of sin. While this is most easily understood in theological terms not necessarily appropriate to this exercise, that language is used in documents of the social teaching of the Church ranging from Immortale Dei and Rerum Novarum of Pope Leo XIII in the late $19^{\text {th }}$ century to Laudato Si of Pope Francis and the coming update to the Catechism of the Catholic Church that will include ecological sins related to the concept of integral ecology (Francis 2019). Limitations are 
exceeded because humanity often forgets his own limits and embraces activities that aggrandize the self in such a way that it breaks or damages the relationship with God and harms other people. As the Catholic philosopher and humorist GK Chesterton says of sin and self-aggrandizement, "one can hardly think too little of one's self," (Chesterton 2012, p. 9). If the development literature has made anything clear, individual people and nations will have to think less of themselves and more of other people in order to address the ecological crisis (Thoreson 2015; Pierre 2011).

So, what is the human person? Most basically, a human is a being who "thinks and wills. He conceives the absolute, the necessary, the immutable, the eternal, the divine, and he loves them. Here at this point Nature would seem to have made a sudden leap, as it were," (Moore 1942 pg. 42). That leap can be overcome through the approach that the Church has maintained and developed over time, one that places individual human beings as embedded in their particular environments, beginning with the family and moving on into the broader society. An Integral Ecology further embeds this concept into the natural, created world, and requires the policymaker and everyday person to recognize that life not only transcends consumption, but that consumption and our activity more broadly can have grave consequences for others. It is the understanding of the human person as embedded in society that provides the key, and it is to the first society that this examination turns to next. 


\section{The First Society: The Family}

\section{The Love of Husband and Wife is the force that welds society together.}

--St John Chrysostom (5 ${ }^{\text {th }}$ Century AD)

While Christ is to be the cornerstone of society, the foundation of society is the family (Pius XI 1925). Pope Leo XIII says of the family "Hence we have the family, the "society" of a man's house - a society very small, one must admit, but none the less a true society, and one older than any State. Consequently, it has rights and duties peculiar to itself which are quite independent of the State," (1891, pp12). This is the doctrine of subsidiarity at its core, for the family exists prior to the state. The state exists to serve the family, not to command the family or to replace the essential functions of its members (Esolen 2012). For the Catholic, Christ is the cornerstone of society because only religion can create a social bond, which is stronger than any contract envisioned by liberal social theorists. "For Leo sees another dimension, the moral and spiritual depth of man-what makes it impossible for us to reduce him to his material wealth and appetites. I enter a contract, for self-serving and limited purposes; but I forge a bond. The bond is personal, engaging the whole of my being. And the social bond aims at the good of that whole human being," (Esolen 2013). The purpose of the state is to provide for stability, as liberals will say, but also, and perhaps first, to provide an environment that makes moral excellence and virtue not only possible but where the virtues can thrive (Esolen 2012x, Leo XIII 1891).

The Catholic Church declares the family to be the cornerstone of society not for utilitarian reasons, but because the family has rights that exist prior to society and prior to 
the State (Leo XIII1891 para. 7; JPII 1991 para. 11). The rights of the family come from God and are natural by design. American Catholic philosopher Anthony Esolen describes the nature of the family and its rights clearly: "It is a society both human and divine. It is within those bonds of love or duty that children and parents both put faces upon law that would otherwise remain abstract, distant, sometimes threatening, sometimes impotent, but always extrinsic, and therefore not quite real. It is there, and only there, that law and love may be found growing together," (Esolen 2012). The family is the first society. It is when families come together that larger communities are formed, be they tribes, neighborhoods, towns, cities or states. It is within the family that the values of society are passed from generation to generation and it is within the family that a society thrives culturally or dies.

The family exists prior to the state and its relationship to the state is indicative of the nature of society. "The family is the test of freedom; because the family is the only thing that the free man makes for himself and by himself," (Chesterton 1990 pg. 24). This is because the family, and indeed all of human society, emerges not from some social contract but from the union of man and woman in marriage (Leo XIII 1880). The Second Vatican Council describes the conjugal union as a sign to the broader society as a sign of Christ's love to the world that was possible for people to emulate; the love between a man and wife can be the model for society because of its self-giving nature (C Church 16011650). The family is the model for society because all members of society come from families, as the family is the cell of society, which illustrates the ideal unity of society, both locally and across the human race, for the unity of the Trinitarian God is reflected in the family, and the family bond should build the bond of the greater human race (PCJP 2004). 
St. Thomas Aquinas goes further. The family is given a priority in society, not out of importance but because of development. For Aquinas, society and politics is focused on a higher good than the family (the virtuous society). The priority of the family is one of development due to the reliance on civil society for stable and functional families. The virtuous society presupposes strong families, which are built both on natural urges to reproduce and the virtues learned in governing those impulses and instead focusing that drive towards providing the material and social support needed for the raising of children (Aquinas, Politics, 1:1:18). As families grow and proliferate, societies are formed for mutual provision of necessities and luxuries, which promotes the division of labor. The needs of the family and the desire for necessities, comforts, and security drive the formation of civil society (Aquinas, 1:1:27). This is a point that is touched on further in Chapter 6, which focuses on economics and the development of a sustainable economy.

What does this have to do with sustainable development? One criticism of sustainable development policy programs is that they often promote the values of the highly individualistic countries and their governments that often fund this body of policy work. One example of this is found in the work of Benarjee in the critique of the sustainable development revolution being "simply a logical extension of the "chemical revolution' of the 1950s and not only serves to sustain corporate and scientific structures of power by creating intellectual property rights in life forms but also threatens to colonize life forms and recolonize spaces in the Third World, a region that contains two-thirds of the world's plant species," (2003, pp. 165-166). One sustainability advocate notes that researchers consistently find that "culture is an effective predictor of people's relations with 
the planet. They consider a global shift towards mindsets that value collective goals over personal ambitions to be a critical step in global transformations towards sustainability," (Soloviy 2019). For the Church, the focus on the family underscores an incompatibility with liberal individualism because the individual is second to the family and society. The primacy of the family and community bespeaks a communitarianism that is incompatible with individualism. For the liberal, the individual has primacy and orders his life to his personal will. This view of the contemporary culture is denounced by Alasdair MacIntyre as "the new dark ages" in the closing pages of his seminal work After Virtue, where MacIntyre describes the course correction that is needed in the modern world is a restoration of a community-centered being for people of all walks of life (MacIntyre 2013, p. 263). This is of course a complicated issue to achieve in the modern setting (Osborne 2008), but the Church offers that a restoration of the centrality of the family on the societal level will create a more sustainable and just society. The complexity of this issue that few scholars want to address outside of Catholic intellectual circles is the subject of the social reign of Christ the king, which has immense implications for development and policy making.

\section{The Society and Religion}

For the Church there can be no greater source of justice and integral human development than the restoration of the kingship of Christ. The people of the world do not enjoy a state of peace, which is the aspiration of humankind, and have not in the modern era. Writing in 1922 in the encyclical letter "On the Peace of Christ in His Kingdom" in 
the aftermath of World War I, Pius XI describes an international political order that bears

striking resemblance to the contemporary political order:

Public life is so enveloped, even at the present hour, by the dense fog of mutual hatreds and grievances that it is almost impossible for the common people so much as freely to breathe therein. If the defeated nations continue to suffer most terribly, no less serious are the evils which afflict their conquerors. Small nations complain that they are being oppressed and exploited by great nations. The great powers, on their side, contend that they are being judged wrongly and circumvented by the smaller. All nations, great and small, suffer acutely from the sad effects of the late War. Neither can those nations which were neutral contend that they have escaped altogether the tremendous sufferings of the War or failed to experience its evil results almost equally with the actual belligerents. These evil results grow in volume from day to day because of the utter impossibility of finding anything like a safe remedy to cure the ills of society, and this in spite of all the efforts of politicians and statesmen whose work has come to naught if it has not unfortunately tended to aggravate the very evils they tried to overcome. Conditions have become increasingly worse because the fears of the people are being constantly played upon by the ever-present menace of new wars, likely to be more frightful and destructive than any which have preceded them. Whence it is that the nations of today live in a state of armed peace which is scarcely better than war itself, a condition which tends to exhaust national finances, to waste the flower of youth, to muddy and poison the very fountainheads of life, physical, intellectual, religious, and moral, (Pius XI, 1922a, p11).

According to Pope Pius XI, this continuing cycle of violence and degradation exists because the kingship of Christ has been rejected in both the public and private spheres (McCall 2011; Pius XI 1922b). One scholar describes the situation succinctly: "Some of the ways in which the economic systems in existence in the world of Pius XI, and today, fail to acknowledge Christ's kingship is by placing an inordinate desire on material things and economic prosperity. What constitutes an inordinate desire? It is when our primary purpose in creating, executing and judging economic laws and behavior is 
economic prosperity rather than seeking first the kingdom of God and His justice. To repeat, this does not mean the efficiency or economic effects of law and policy are irrelevant, but they must be of secondary, not primary, importance," (McCall 2011). This statement by McCall recalling the underlying logic of Pius XI and his predecessors complements the work of sustainable development advocates, such Arima, who argues that sustainable development must focus first on education, and then on economics (Arima 2009). Another example of this thinking is featured in Holden, where the good of human beings must come prior to the comfort and luxury of desires (2014). The pursuit of economic growth and prosperity are a means to securing justice, not the ends of justice itself. For the policy expert, this subordination of efficiency to religiously inspired norms of justice can serve as a difficult barrier to overcome, as sustainable development is centrally concerned with what can be described as "eco-efficiency" (Borza 2014). Ecoefficiency is often criticized as lacking concern for equity and social justice broadly, though in recent years there has been an attempt to include this concern in the eco-efficiency literature, which often focuses on industrial aspects of sustainable development (Huppes and Ishikawa 2009; Ehrenfeld 2005).

It is essential to understanding the socially just and sustainable paradigm in the vision presented in Catholic Social Teaching that everything revolves around the social reign of Christ the King (Pius X 1906). This ordering of society to the reign of Christ does not respect the contemporary secular dividing of society into public and private spheres of life. "If this power embraces all men, it must be clear that not one of our faculties is exempt from His empire," (Pius XI, 1922 para.33). This society is one that recognizes itself as a 
society of sinners that know only through Christ can redemption and peace be attained. How is such a society attained? "How do we build such a society? That is the wrong question. We do not build it at all. We allow Christ to build it for us. The source of our union does not lie in our will, our cleverness, our political machinery, even our virtues, such as they are. They lie in Christ," (Esolen 2014, p. 180). The social unity of people through Christ transcends political systems, cultures, and nations. It is a universal call to brotherhood through the love of neighbor and is why the Church has historically been able to work with political systems of all kinds ranging from democracies to military dictatorships. Christ transforms society by transforming individuals and families. It is not a call by the Church for the institution of theocracy and the institutionalization of authoritarian rule by clerics (DH 1965). For the Catholic, it is a call for personal conversion and the spreading of the Gospel that will lead to the transformation of society.

The consequence of the spreading of the Gospel will be profound, according to the Church. "When once men recognize, both in private and in public life, that Christ is King, society will at last receive the great blessings of real liberty, well-ordered discipline, peace and harmony," (Pius XI, 1922 para.19). This transformative harmony re-orders all relationships in society to one that fully lives in accordance with Christian values of temperance, moderation, and self-sacrifice.

To our modern, liberal and socialized ears, the words of Pius XI sound like a call for theocracy. The way forward must be voluntary, which the Church has always taught (DH 1965; Pius XII 1943). Instead, the call for conversion falls under what John Paul II 
called The New Evangelization, and the logic behind The New Evangelization can be instructive for the use of Catholic Social Teaching in the efforts for developing sustainability policy in that what John Paul II's efforts called for was a lay-focus for the spread of the Gospel; it is indeed the laity doing the vast majority of the work of sustainable development and social justice, as will be demonstrated in later chapters. The New Evangelization is a call for Christians to consciously live their faith: "To this end, it is more necessary than ever for all the faithful to move from a faith of habit, sustained perhaps by social context alone, to a faith which is conscious and personally lived. The renewal of faith will always be the best way to lead others to the Truth that is Christ,"(JPII $1999 \mathrm{pg}$. 127). One consequence of this renewal of faith would be a focus of "man's activity for his integral liberation, the search for a society with greater solidarity and fraternity, the fight for justice and the building of peace," (JPII 1979, pg.624) and the restoration of the pursuit of virtue in society in line with traditional Christian virtues whose absence and rejection in the modern world have led to gross imbalances and disharmony between a person's relationship with his neighbor and with Creation (Francis 2015). What is called for is a conversion of the person on a massive scale, which like individual conversion, is always freely chosen if it is to be authentic (DH 1965). Pope Pius XI called for a calling and conversion of all things to Christ; not some things, but all things, for to not align all things to Christ is a false conversion and turns Christ into a false idol (Pius XI 1922). The logic should be clear at this point: for Catholics, the duty is to spread the Gospel and the modes of Christian living in large part through their own example. There is an obvious break between belief and practice in this, which can be rectified through application of Catholic 
Social Teaching in the developing world as well as in countries like the United States where Catholics engage in the materialist activities fueling the climate crisis at the same levels that non-Catholics do (Francis 2015).

What would this look like? What would economics look like in a society oriented towards Christ? Would the economics of constant growth be a feature of this order? Would political systems be hierarchically ordered and centered in top-down political structures as they frequently are in the contemporary secular social order? Would the relationship between humankind and the environment be one of ontological alienation and separation that some characterize as a relationship of exploitation? These are the central questions that are addressed as the process of presenting Catholic Social Teaching as a viable supplement to sustainability is presented in the coming chapters of this dissertation. The basis of this is recognition by the Church that constant growth is not sustainable. The underlying logic of this can be seen as far back as the writings of Leo XIII and Pius XI when the demands of capitalism that require constant expansion and focus of the material at the expense of all other values are rejected (Leo XIII 1891; Pius XI 1931). This is compatible with the assumption that underscores much of the sustainable development literature, that there are limits to growth that challenge our economic assumptions (Daly 2008, 9-25).

One thing that must be done is to differentiate what the Church offers against the alternative, that is, the culture dominating the West and, through the influence western culture has in a globalized society, across the globe. That culture has been characterized as a 'Culture of Death' by Pope John Paul II. This culture is rooted in practices, institutions, 
and values that create a tradition. Archbishop Martinez describes this culture as a nihilism institutionalized. "Nihilism is today not a philosophy, it is above all a practice, and a practice of suicide even if it is a soft suicide. It is the suicide of the depressed. It is also a practice of violence. The secular society lives in daily violence, violence with reality. This violence shows that nihilism cannot and does not correspond to our being. But it shows also, in a very concrete way, how the secular society annihilates itself by engendering the very monsters that terrify it most and that it itself hates most," (2004 p.31). What the Church proposes is not simply life and family defending theories and theology but practices that are attractive to those lost in the nihilistic culture that offers healing and rebuilding from the wreckage left by a culture lost in the traditions of self-worship that only leads to death (Kozinski 2012).

The Church's primary task is not provision of social services, promotion of social justice, activism, or other activities of the kind. The principle mission of the Church is the spreading of the Gospel and catechesis (John Paul II 1979). The Church's mission is to spread the Gospel to all peoples everywhere through peaceful means, for Christianity cannot be embraced by force, either in any logically coherent manner or in any way that respects human dignity (John Paul II 1979), "without coercion on the part of individuals or of social groups and any human power," in such a way that in this matter of religion, "no one is to be forced to act against his or her conscience or prevented from acting in conformity to it," (Synodus 1977 para.2). Nonetheless, this primary mission of spreading the Gospel is often best achieved by pursuing the goals and aims of CST and social engagement. Human dignity is essential to a Catholic social order, which relies on the 
primacy of a rightly formed conscience. That must be understood both by policy makers and by Catholics who would want to implement Catholic Social Teaching in the political or economic order, for at its core Catholic Social Teaching is a path to creating a just and sustainable social order that respects human dignity and strengthens the spiritual dimensions of life, not through the imposition of tyranny but in the presentation of human needs and wants in a more sustainable way. 


\section{Chapter 4 Social and Political Arrangements}

Political freedom without economic freedom is almost worthless, and it is because the modern proletariat has the one kind of freedom without the other that its rebellion is now threatening the very structure of the modern world. - Hilaire Belloc (1937)

The intersection of political theory and sustainable development is a critical area of discourse that addresses the needs of governance, human rights, and the relationship between people and their government. Having divided this and the following two chapters into the framework of sustainability (social and political, economic, and environmental), this chapter focuses on what Catholic Social Teaching says of social sustainability and how the just, well ordered society should be organized.

\section{On the Ordering of Political Society}

The Magisterium of the Church has said precious little about specific forms of government. However, central concepts of Catholic Social Teaching have tremendous implications for governance, all of which point to national governments playing a minimal role in society. The exploration of this subject will help to illustrate not only the illiberal nature of the ideal Catholic society but also why the Church can make the claim that the

liberal and socialist societies (or the materialistic philosophies born from liberalism and socialism) are unsustainable and unjust. To examine that claim it is prudent to begin at the beginning. 
Traditionally, the Church argued in defense of monarchy and against Republicanism and Liberalism. The foundational argument comes from St. Thomas Aquinas in de Regno, where he states that the only rule which is directed "towards the common good of the multitude is fit to be called kingship," (Aquinas 2014). The rule by one person who "seeks his own benefit from his rule and not the good of the multitude subject to him" is nothing more than a tyrant. Aquinas argues that "Just as the government of a king is the best, so the government of a tyrant is the worst," maintaining that rule by a single individual is the most efficient for accomplishing either good or evil purposes. He then proceeds to discuss "how provision might be made that the king may not fall into tyranny," stressing education and noting that "government of the kingdom must be so arranged that opportunity to tyrannize is removed," implying that a limited monarchy with checked power is preferable (Aquinas $1997 \mathrm{pp} 66-70$ ) .

The Church has not formally argued for monarchism since the $19^{\text {th }}$ century. Instead, the focus of Catholic Social Teaching has been on the ends of government. John Paul II defined the ends of government succinctly in his criticism of liberalism and democracy in Evangelium Vitae, where the pope saw liberal democracy as denigrating the truth and praising efficiency that enabled a "war of the powerful against the weak." Freedom, liberty, and individualism served to hide a "culture of death" from the eyes of the masses. In Centesimus Annus, John Paul II stated that the chief issue with democracy, and especially liberal democracy, is the atomizing individualism of the culture that is associated with liberal democracy. "To overcome today's individualistic mentality, a concrete commitment to solidarity and charity is needed, beginning in the family," (JPII 1989, para 49). The 
family is the bedrock of society, and any society, democratic or otherwise must support the family as a sacred inviolable institution.

The objection is predictable. The Church has routinely "worked with" dictators in the past (Floyd 2015). The claims of the Church being concerned with human dignity ring hollow if the complicity of the Vatican and the Bishops with Latin American and African dictators is any indication. This argument is made by secular commentators across the board, including Mignone (1988) who cites the actions of Argentinian bishops working with dictators during the revolutionary period in that country that lasted from the 1970 s through 1983, including Archbishop Jorge Bergoglio (Pope Francis). Many of those bishops are known for not having objected vociferously to the actions of the post-Peron dictators, as well as aiding and abetting the persecution of Argentinian resistance fighters. For example, despite the murder of bishops and priests of conscience, the Vatican and the bishops are said to have remained in steadfast support of General Jorge Rafael Videla (Mignone 1988).

To better understand what the Church teaches about society and political life, and to better understand why the Church has been able to have functional relationships with governments of most times (seemingly, excluding hardline socialist ones), it is worth exploring what the Church has said about the organization of society, keeping the concept of subsidiarity in mind. Pope Paul VI, writing in 1971, has stated that the natural condition of human beings is to search for means of organizing themselves into various groupings that promote human dignity and human flourishing. 
The Christian has the duty to take part in this search and in the organization and life of political society. As a social being, man builds his destiny within a series of particular groupings which demand, as their completion and as a necessary condition for their development, a vaster society, one of a universal character, the political society. All activity must be placed within that wider society, and thereby it takes on the dimension of the common good [...]. Political activity [...] should be the projection of a plan of society which is consistent in its concrete means and in its inspiration, and which springs from a complete conception of man's vocation and of its differing social expressions, (Paul VI 1971 para 24).

There is no universal form of government that guarantees human flourishing, nor is there any political philosophy that can be applied to all cultures, ethnicities, or societies that will promote human flourishing, which can only be accomplished through the protection of the family as the cornerstone of society and the recognition that individuals possess special dignity that must be protected.

While the Church has historically been a defender of monarchism, in the age of democracy the magisterium and Catholic thinkers have written extensively on democracy. John Paul II issued warnings against holding democracy itself as an absolute value. "Democracy cannot be idolized to the point of making it a substitute for morality or a panacea for immorality. Fundamentally, democracy is a 'system' and as such is a means and not an end. Its 'moral' value is not automatic, but depends on the conformity to the moral law,' (JPII 1995). This is because morality must be of root concern to the state, for a stable, sustainable society is one in which the moral law is realized and adhered. The danger, John Paul II states, is that democracy will bring with it any number of social ills that contribute to the rise of a 'culture of death,' that is, a culture that does not value human life and sees life as a means to an end instead of an end in itself (JPII 1995). 
The issue at hand is liberty. While liberty has been touched upon briefly in previous chapters, especially concerning intellectual liberty, the primacy of the individual is a value of secular society that underpins modern liberal and social democratic societies across the world today. For example, Hall states that any conception of freedom must begin with understanding the nature of the individual, with modern conceptions of freedom entailing the maximized rights of the individual to act as long as those actions do not conflict with the rights of others to act (Hall 2012, 229).This formulation is the classic liberal notion of freedom that dates back as far as John Locke in the $17^{\text {th }}$ century. Locke stated “"'Being all equal and independent, no one ought to harm another in his life, health, liberty, or possessions." "Men being, as has been said, by nature, all free, equal and independent, no one can be put out of this estate, and subjected to the political power of another, without his own consent," $(1990,455)$. The essence of liberty is the issue of individual conscience, an issue that which both the traditional magisterial teaching of the Church and the secular authorities generally agree upon. The Catholic Church formally states in the Catechism of the Catholic Church that the individual has the right to act upon their conscience as long as the conscience has been properly formed in keeping with the morality of the Catholic faith (C Church 1776-1794, 1995). True individual freedom, in the Catholic view, is the freedom to act according to the well-formed conscience (Velez 2009). But the essence of the disagreement heavily rests on the nature of individual conscience and the understanding of what this entails. Note, before proceeding, that the forms of government are not a major concern of the Church. Rather, the political concerns of the Church are that secular political authorities will respect human dignity and individual conscience. But what does this mean 
precisely? And how does this concern for individual conscience inform what political structures should look like in a sustainable society?

\section{Subsidiarity}

A central theme in Catholic Social Teaching regarding governance is the concept of subsidiarity. While subsidiarity was defined in an earlier chapter, it is worth revisiting subsidiarity and its definition again. Subsidiarity is a term derived from Latin that means 'aid, help' (subsidium) and can be defined as whenever practical, political and social decisions should be made by those most affected by the outcome of the proposed actions (John Paul II 1991 para. 48c). In considering government action, the principle of subsidiarity means that in a truly Catholic and sustainable society, justice requires that the national government only do what the next lowest level of government cannot, on down the chain of government. Communities do what families are incapable of doing, and families only do what individuals cannot. This sounds similar to obscure political theories such as anarcho-capitalism or monarchism, but in truth is different (Block 2007; Long and Machan 2012). Popes including John XXIII have argued for specific policies such as national health care, unemployment insurance, minimum wages, and government patronage of the arts on the grounds that supporting these policies contributed to the common good and were outside the feasible scope of local government (John XIII 1963). Pope Francis expands upon this concept, reminding governments that those who govern have a duty to intervene when local governments do not have the capacity to address social 
and environmental problems adequately. This includes supranational organizations and the need for global coordination to address the climate crisis (Francis 2015, 175).

Despite many popes and other Catholic figures calling for some level of government involvement in providing goods in society, a planned economy violates subsidiarity (Catholic Encyclopedia, 1965). According to Pope Pius XI (1931), "Just as it is wrong to withdraw from the individual and commit to the community at large what private enterprise and endeavor can accomplish, so it is likewise unjust and a gravely harmful disturbance of right order to turn over to a greater society of higher rank functions and services which can be performed by lesser bodies on a lower plane." A respect for human dignity requires recognition of the autonomy of the human person, either as individuals or when acting in concert in free associations. This is similar to the literature in the sustainable development community that calls for local control of development efforts by local actors instead of by large multinational non-profits, governing agencies, or foreign powers (Cooper and Vargas 2004). Subsidiarity is a concern that sustainable development practitioners must grapple with, as funding often comes from national governments but have policy goals that may conflict with local cultures, peoples, values, and, governance. Subsidiarity, rightly understood in either a Catholic or purely secular program, favors autonomy of the individual and local peoples as far as possible, with policy programs empowering non-local actors only when the issue programs are meant to address are outside the possibilities of local authorities to enact. But subsidiarity is a principle meant to protect the autonomy of local peoples and individuals whenever possible. 
This idea is described by GK Chesterton, to which a lengthy quote is worth exploring:

The democratic contention is that government (helping to rule the tribe) is a thing like falling in love, and not a thing like dropping into poetry. It is not something analogous to playing the church organ, painting on vellum, discovering the North Pole (that insidious habit), looping the loop, being Astronomer Royal, and so on. For these things we do not wish a man to do at all unless he does them well. It is, on the contrary, a thing analogous to writing one's own love-letters or blowing one's own nose. These things we want a man to do for himself, even if he does them badly. I am not here arguing the truth of any of these conceptions; I know that some moderns are asking to have their wives chosen by scientists, and they may soon be asking, for all I know, to have their noses blown by nurses. I merely say that mankind does recognize these universal human functions, and that democracy classes government among them. In short, the democratic faith is this: that the most terribly important things must be left to ordinary men themselves - the mating of the sexes, the rearing of the young, the laws of the state. This is democracy; and in this I have always believed. (Chesterton 1909, pg. 83).

The principle of subsidiarity is clearly favorable to democratic systems, as Chesterton illustrates, though it doesn't necessarily require democracy to flourish. Subsidiarity is not to be confused with federalism, though federalism is often compatible with subsidiarity. Federalism is traditionally defined as the mixed mode of government, which combines a central with regional governments in a single political system. A defining feature of federalism is a relationship of parity or defined power between the various levels of government. Federalism is most simply defined as a division of power between various levels of government where each is superior in its own realm (Wheare 1946, Law 2013). This is of course ignoring the various styles of federalism that have dominated American politics in the nation's history. Revisiting subsidiarity, the term is typically defined as, in 
the policy or governance sphere broadly, whenever practical, political and social decisions being made by those most affected by the outcome of the proposed actions (Esolen 2012); subsidiarity is a concept of decentralized governance that seemingly paradoxically requires an overarching central authority to make feasible (King 2014). This only seems paradoxical until it is remembered that subsidiarity is a concept advocated by proponents of monarchism who have since re-applied to concept to contemporary issues of governance.

Subsidiarity is concerned with the most local level of decision making that is proper. What determines what is proper? Several concerns go into understanding what is proper, first among them is human dignity. While there certainly are similarities between the two visions of governance, there are also differences. Federalism, at least in the American mold, is the concept that certain functions of government belong to more localized actors. We can see this today in the further development of decentralized local forms of government, which approach 89,000 units of government today (US Census 2012). This tendency of American government is lauded by Pope John Paul II when, citing Pius IX, describes a functioning state in-line with subsidiarity as "a community of a higher order should not interfere in the internal life of a community of a lower order, depriving the latter of its functions, but rather should support it in case of need and help to coordinate its activity with the activities of the rest of society, always with a view to the common good, (John Paul II, 1891, $\S 48)$.

Where subsidiarity and federalism differ is simple. Federalism is about government action and assumes some level of government is the appropriate actor. Subsidiarity does not assume government is always or even usually the necessary actor. Often the state creates conditions through its actions that can impair economic activity that undermines the Common Good (John Paul II 1989, §15). Rather, subsidiarity assumes that people have the right to form free associations to address needs without necessarily resorting to government action; this was a phenomenon that de Tocqueville described in great detail in 
his writings about the America of his day when he wrote at length about the free associations that dominated the American landscape in the 1830s, and which were in his reckoning the great strength of the United States (1832 pp 489).

An essential issue in understanding subsidiarity and federalism is scale. While sustainability is certainly about social structures that lead to marginalization of peoples and environmental degradation that frequently accompanies it (Lee and McGahan 2015), at the heart of the issue is management of common pool resources (CPR). Ostrom's landmark 1990 study identified numerous cases where CPRs were managed effectively and several where management efforts failed. Ostrom provided a new model for governance as a means of addressing failures, a third way, which focused on establishing of durable cooperative organizations that are built and governed by the resource users (Ostrom 1990). Local decision-making and authority in governing common pool resources can be important for achieving local buy-in for affected populations (Ostrom, 1990), fostering economic development (Sabel, 1989), and ultimately the development of meaningful democracy (Putnam, Leonardi and Nanetti 1994).

Scale becomes an issue in federalism and subsidiarity due to complexity, either of dimensions of the problem or simply due to the size and scope spatially. Scale is defined by Marshall (2008) as "the temporal, spatial, quantitative or analytical dimensions used to measure or study any phenomenon, whereas 'level' refers to units of analysis located at different positions on a given scale," (76). An example of this complicating the issue of subsidiarity would be when CPRs cross jurisdictional boundaries, such as a watershed that 
runs through multiple water districts or even across provincial or national boundaries. The approach offered in the secular literature that is compatible with the CST understanding of subsidiarity is the concept of nesting authority or nested subsidiarity. Ostrom (1990) describes this as the "appropriation, provision, monitoring, enforcement, conflict resolution, and governance activities [of common property systems of common pool resource management] are organized in multiple layers of nested enterprises," (90). The issue of scale reflects the meso-level of governance, that place between the purely local and the purely national or supranational level of policy where the majority of sustainable development work is done. Scale and the nesting principle become important to understanding the application of the principle of subsidiarity in the development policy world.

In an address to EU leaders, Pope Francis made an appeal for greater subsidiarity in the face of growing European centralization. Pope Francis urged them to embrace "a spirit of solidarity and subsidiarity," only which "can make the Union as a whole develop harmoniously," (Francis 2014 para. 16). The traditional understanding of subsidiarity as it compares to contemporary sociopolitical arrangements is that there is an absence of subsidiarity that contributes to "the sense that there is a growing 'split' between the citizenry and the European institutions, which are often perceived as distant and inattentive," (Acton 2017). The same is often said of American politics in recent years, which has been described to have fed into the rise of populism in the United States and elsewhere, which theorists describe as a crisis in the public faith in democratic institutions and systems (Moffit 2016). In turn, this greater cooperation in the spirit of democratic 
participation in the management of CPRs can foster greater trust throughout the system, bolstering societal trust (Scheberl 1997). The call for greater subsidiarity is a call for greater decentralization of political decision-making to those most affected by the consequences of those decisions. This decentralization is born from the traditional teaching of the Church that most often decisions are best made by the most local authority possible; this does not preclude national governments from making important decisions. Instead, subsidiarity is most concerned with local associations, individuals, and organizations making decisions for themselves as free as possible from external pressures that may require them to act in immoral ways that violate the duties of those involved.

Subsidiarity is seen in secular governance in the Amsterdam Treaty of the European Union, which emphasizes community action if the governance issue cannot be addressed by the member states (Follesdal 2000). The concept is similar to what the Church teaches but is not the same, as member states of the European Union have primacy in this definition, with little thought given to whether the proposed action is appropriate to a unity of government hierarchically above the local unit, or if government is the appropriate actor in a given situation. In the secular literature on democratic deliberation this tension is a point of debate, with the Amsterdam definition of subsidiarity seen as deficient (Follesdal 2000; McCormick 1997). At issue is the respect for autonomy of individuals and local communities, which is often criticized as lacking in this formation by democratic theorists who value deliberative democracy (McCormick 1997).

This sense of a need to respect the duties of individuals and their rights to form free 
associations for acting is the central concern of solidarity, without which subsidiarity is almost meaningless, and together which forms the backbone of Catholic understandings of political, social, and economic action.

\section{Solidarity}

Much of political governance can be accomplished outside the halls of government, through free associations. This is not a particularly radical notion unique to Catholic Social Teaching. Frederickson (2005) asserts as much when speaking about the tendency of governments to contract-out much of the work traditionally thought of as government work. This reflects the growing understanding that the boundaries between politics, policy, and public administration are fuzzy and always changing (Frederickson 2005). This is due in part to the "hollowing out" of governance and service delivery since the implementation of New Public Management programs of the 1980s, which sought to improve government efficiency by having the state borrow methods from the world of business couched in the language of economic rationalism (Hood 1995). The complications from the purely rationalistic model of New Public Management led to reforms under the guise of a New Public Governance, that was heavily value-laden with the intent of overcoming the consequences of a purely utilitarian approach that New Public Management was often accused of. The New Public Governance infuses values that are designed to remind the public servant that the work they are doing is purposed with the common good in mind (Morgan and Cook 2015). This is clearly a link between the established mode of thought 
in Public Administration and governance theory and CST.

This new era of governance debate has been rife with debate and controversy, warranted or not. One such example in the western world is the case of the I69 highway project in Indiana. Launched in 2014, the highway project was the classic public private partnership of the modern American political world, with government funds being used to hire contracting firms from around the world to develop and manage a section of the federal highway infrastructure for 35 years at cost estimates that would have saved tens of millions of taxpayer dollars but in the end had severe cost overruns due to poor oversight, corporate corruption, and unforeseen circumstances (DeGood 2018). The numerous examples of public/private partnerships gone awry should be noted when attempting to implement such programs in the developing world. There have been success stories from public and private partnerships (PPP). For example, the Australian Pacific Highway Upgrade project in 1996 is a model for success despite adverse and complex circumstances, including environmental conditions that proved challenging, as well as partner companies and agencies having no history working together. This required the partner organizations to develop guidelines and principles for working together. The project finished seven months ahead of schedule and under budget (Maltin 2019). Success stories often require several factors, including favorable legal framework for PPP, commitment and responsibility of public and private sectors, typically meaning a strong identification with a view towards the common good, competency of companies and agencies, stable macroeconomic environment, and an appropriate allocation of risks and sharing (Cheun, Chan, and Kajewski 2012, 50-52). 
That having been noted, however, this conception still emphasizes some role for government, which Catholic Social Teaching does not always assume. Pope Paul VI in Populorum Progressio addressed the rising concern of development and the human conditions that was of central importance in the mid-1960s through the lens of integral human development. This will become more important when the issue of economics is addressed in the coming chapters.

Human development has several elements, including culture, family, the community, environmental concern, and human rights. Paul VI was heavily influenced by Catholic theorists like Maritain and Lebret, as well as traditional Catholic calls for voluntary reallocation of the world's wealth through voluntary association fueled by Christian virtue. The pope insisted that the wealthy nations voluntarily give wealth to poorer nations in order to assist them in their development. This was a radical turn in Catholic Social Teaching, or so it seems on a superficial level, as George Weigel has been criticized for in his infamous attempt to examine Catholic Social Teaching in an American neoconservative framework (Annett 2015). This understanding was grounded in solidarity, which can be understood as human beings living in close relationship with each other both locally and, in Paul VI's understanding, on a national and international level (Paul VI 1965; Paul VI 1967). Nations have a similar moral obligation as individual persons and families. Recall that it is a mistake to understand human beings as either atomistic individuals or faceless members of a collective. Each resides in relationship with one another, from the family level through the international level of analysis in a modern complex global system. Neither individuals nor nations should exist to look after their own interests exclusively. 
Yes, nations and people have a duty to the common good of their citizens and neighbors first, but others must be considered as well. At the most basic understanding, this is what Francis means by integral human development or the new humanism (Francis 2019), and the implications the concept has on development policy are enormous.

The popes of the post-conciliar era wrote extensively on the development of peoples, and even encouraged secular advocacy of sharing wealth internationally. It was at this time that what came to be called 'sustainable development' was gaining traction in western political thought as western nations sought to address endemic poverty, political corruption, and environmental degradation in the midst the Cold War (Pisani 2006). In Populorium Progressio (1967) Pope Paul VI called for "a new humanism" that emphasized interpersonal relationships and the support of growing spiritually in the faith. For Paul VI and his successors, integral development means "authentic development-his transition from less than human conditions to truly human ones," (1967 para. 20).

Perhaps no Pope has explored the idea of solidarity more than John Paul II. The pope called solidarity the 'pathway to peace,' and called it essential to making both peace and integral development a reality in the modern world (John Paul II 2004). John Paul II was focused on the concept to such a degree that the term appears 54 times in his encyclical contributions to Catholic Social Teaching. While the concept is described by John Paul II as a central concept in the social teachings of the Church, there is no fundamental agreement as to its meaning (Njoku 2007). Thus, a certain ambiguity remains, which some scholars like Njoku criticize. Yet it can be argued that the social teaching of the Church is 
filled with what can be called ambiguity due to the fact that the purpose of the social teaching of the Church is to provide concrete moral guidance to various disparate sociopolitical contexts. Thus, solidarity and subsidiarity have essential meanings that remain true across the diverse systems that characterize human societies around the world while providing universal moral guidance; solidarity is rooted in a love for neighbor that, when combined with subsidiarity, calls for decentralization of political systems as far as is feasible, based on the moral requirement that human beings are primarily responsible for those closest to them first, with government being involved only in areas of great complexity.

Solidarity, especially for popes John Paul II and Francis means mutual recognition of human beings between the oppressed and other persons. Njoku, an African sociotheological academic, is one of the few to deeply interpret this concept.

Furthermore, it denotes independence, communion, Christian charity, forgiveness and reconciliation, commitment to the good of one's neighbor and total self-gift in the service of others, preferential option for the poor, and some terms (used by previous popes) such as: 'friendship,' 'social charity,' and 'a civilization of love.' It relates to participation, the spirit of cooperation, and the absence of oppression, defense of the poor and helpless, the pursuit of the common good, and the readiness to true lifefulfillment to both persons and communal groups. These varied interpretations of solidarity both in John Paul's treatment and in the social sciences underscore an altruistic lifestyle and purport to prescribe the moral and political responsibilities of individuals to a network of communal relationships, (Njoku 2007, pp81).

These are values that can be applied to nearly any political system that does not stand on foundations objectively opposed to Catholicism and the faith's traditional concepts 
of human dignity rooted in the natural law understanding of the relationship between humans and God. The challenges to this in the western world are obvious but in the developing world present more options, with fewer barriers to entry for Catholic Social Teaching. Perhaps ironically, this has been noted in the secular literature when it has been noted that Catholic countries often present the most difficulty for secular NGOs seeking to provide development assistance. For example, Barrow and McLeary demonstrated that higher levels of religiosity in a state have a negative effect on economic development (2003). This can be demonstrative of numerous issues at play, most importantly the conflicting of values due to miscommunication that undermines the efforts of NGOs to do the work of supporting the vision of the common good that John Paul II stated above, not out of malice but out of a lack of awareness. These issues can include a conflict relating to deeply held religious and moral values including the value of human life from the beginning of life to the nature of competing market forces and the impact of marketization of developing countries on the family. The role of NGOs has been traditionally described as "provid(ing) a third approach to development between market-led and state-led strategies," (Makoba 2002). In turn, Catholic Social Teaching provides an alternative way or at least alternative set of inputs to be considered that may help bridge morals and values conflicts between state actors, international actors, and NGOs that seek to promote the development of sustainable political arrangements when values are in conflict. Solidarity as a core guiding principle offers NGOs a means of embracing what Makoba referred to as a "shift towards people-oriented programs" that promote "assisted self-reliance" and “participatory development” (Makoba 2002). This value, as described by Makoba, is John 
Paul II's mutual respect of persons between the development agent and the local actors at all levels, be they the agents of the governments or the persons in local communities most affected by proposed programs.

This may require a different approach to the issue of the separation of Church and State, at least for the development provider. The Church has traditionally opposed the separation of Church and State because, classically, the State should create conditions that the Church can thrive in for the promotion of virtue and the salvation of souls, and the Church reinforces the authority of the secular state by helping to foster a virtuous population (Ferrara 2012). While the latter is all-but purely in the realm of theology, the former is the grist of the philosophical mill of political theory, with virtue being the primary purpose of the influence of civil society on the individual person, and the person on the civil society. Values in this way are promoted through the relationship of the lay faithful to the Church, leading inevitably to a more Catholic and just society. The just society can thus be construed to be the society that promotes the well-being of the embedded individual who sacrifices for the better of their family, their neighbors, and the broader society. The development professional, local governments, and community members affected by policy all fall into this area of productive partnership for the common good that, at least for the populace who holds these values, would be influenced by the high priority given to virtue. Thus the potential of sustainable development in the mold of CST for the NGOs is to provide a means of attaining not only development of more sustainable yet culturally appropriate political or economic institutions, it is to assist in the work of the state and Church authorities in their separate yet compatible work on fostering attitudes that can be 
called Christian charity, the spirt of cooperation, and the absence of oppression.

In an odd way, the policy circles of the secular world acknowledge this as well, with the rise of interest in collaborative governance. Ansell and Gash define collaborative governance as "bring(ing) public and private stakeholders together in collective forums with public agencies to engage in consensus-oriented decision making” $(2012,1)$. Collaborative governance approaches to local policy development and implementation offer one way forward, though the dangers of technocratic intrusion are to be observed and guarded against. Despite what the adherents of collaborative governance will admit, this approach can still be highly technocratic in nature and assumes government role in some form or another in seeking solutions to problems. The social teaching of the Church makes no such assumptions and even in some cases argues for a limited role of government, at least compared to what has been the rule in the modern world since the time of Bismark in Prussia (Leo XIII 1884).

This divorce of technocracy from solution seeking should be of no surprise. The purpose of the social order the Church advocates is one where people can pursue virtuous living, which inevitably leads to a just society, for if the constituent components of society (people) are virtuous, then society will itself be a more just one. Jacques Maritain summarizes this in the following passage:

It is not enough for a population or a section of the population to have Christian faith and be docile to the ministers of religion in order to be in a position properly to judge political matters. If this population has no political experience, no taste for seeing clearly for itself nor a tradition of initiative and critical judgment, its position with respect to politics grows 
more complicated, for nothing is easier for political counterfeiters than to exploit good principles for purposes of deception, and nothing is more disastrous than good principles badly applied. And moreover nothing is easier for human weakness than to merge religion with prejudices of race, family or class, collective hatreds, passions of a clan and political phantoms which compensate for the rigors of individual discipline in a pious but insufficiently purified soul. Politics deal with matters and interests of the world and they depend upon passions natural to man and upon reason. But the point I wish to make here is that without goodness, love and charity, all that is best in us - even divine faith, but passions and reason much more so - turns in our hands to an unhappy use. The point is that right political experience cannot develop in people unless passions and reason are oriented by a solid basis of collective virtues, by faith and honor and thirst for justice. The point is that, without the evangelical instinct and the spiritual potential of a living Christianity, political judgment and political experience are ill protected against the illusions of selfishness and fear; without courage, compassion for mankind and the spirit of sacrifice, the ever-thwarted advance toward an historical ideal of generosity and fraternity is not conceivable, (Maritain 2012).

Of course, the just society has real concerns, especially in the modern world. Strong families are the building block of subsidiarity and solidarity. As one UN expert notes, "They bear the primary responsibility for the education and socialization of children as well as instilling values of citizenship and belonging in the society. Families provide material and non-material care and support to its members, from children to older persons or those suffering from illness, sheltering them from hardship to the maximum possible extent" (IFFD 2020, pg. 1). Economics and environmental concerns need more than what can be called lofty ideas about individual virtue creating a society ordered towards justice. In the next chapters the discussion will turn towards the other areas of justice understood in the context of sustainable development: what a just economic ordering would look like, as well as what a just relationship to the natural environment would be. For now, it is sufficient to say that the just social order is one that understands that families are the 
foundational unit in a society where the Church and the State would together to foster virtues. This is the sustainable society according to the Church, and this vision is one that development specialists must take heed of when engaging in development work in heavily Catholic countries, especially in the developing world.

An emerging question is: can a person or people collectively have a solidarity with nature? The Catholic Social Teaching principal of stewardship suggests on a surface level that it can be, but in truth the solidarity with the environment is really a solidarity with God, author and creator of the natural universe and all elements of the created world. This relationship with God, which I characterize as a deicentric understanding of sustainability, requires that the person individually and collectively subsume their desires to the common good, of both current and future generations, as well as recognizing that all of creation has a dignity inherent to it due to being created by God (Magill 2017). This requires expanding the notion of the common good from merely human needs to encompass all of creation, human and non-human alike (Boff 2015). 


\section{Chapter 5 Economics in the Catholic Society}

"Every man is more careful to procure what is for himself alone than that which is common to many or to all: since each one will shirk the labor and leave to another that which concerns the community," - St. Thomas Aquinas (1265)

Economics has become the lifeblood of modern politics across the world, with employment rates, production numbers, and stock prices having a direct impact on the lives of everyday people. The Church recognizes the important place economics places in the functioning of society and has said a great deal about economics. This chapter will begin with examining two key concepts and then showing how those concepts challenge existing economic assumptions and arrangements. It is in economic discourse that the Church finds some of its greatest criticism from secular theorists, aside from the high profile controversial social issue stances the Church takes. The two concepts to be focused on here are stewardship and solidarity, though little space will be devoted to solidarity.

Stewardship is best defined in a document by the US Conference of Catholic Bishops titled "To Be a Christian Steward" (2005) as "Safeguarding material and human resources and using them responsibly are one answer; so is generous giving of time, talent, and treasure. But being a Christian steward means more. As Christian stewards, we receive God's gifts gratefully, cultivate them responsibly, share them lovingly in justice with others, and return them with increase to the Lord," (pg. 1). In the modern world, virtually everything is a resource and must be charitably shared with others. This has profound 
implications for economics, environmental policy, and politics broadly. But to take this concept in isolation outside of other ecclesiastic and Catholic scholarly economic works would be a mistake. Consequently, stewardship in the context of economics must be understood in several areas of particularly economic interest that the Church has spoken about at great length.

The first area of economic concern is private property. The Church has written at length that private property is an almost sacred institution, though not inviolable. This right is not a legal creation, that is a creation of humans, but is rather derived from the natural law. Starting with Pope Leo XIII in 1891, the Church states that the legal authority (i.e., the State) has the right to regulate the uses of private property in order to support the common good. However, limiting the right to private property through unjust levels of taxation is a violation of the natural law (Leo XIII 1891). Leo XIII restated the Church's historic stance regarding the essential nature of the right to private property while recognizing that the free operation of market forces are subject to the moral law: "Let the working man and the employer make free agreements, and in particular let them agree freely as to the wages; nevertheless, there underlies a dictate of natural justice more imperious and ancient than any bargain between man and man, namely, that wages ought not to be insufficient to support a frugal and well-behaved wage-earner. If through necessity or fear of a worse evil the workman accepts harder conditions because an employer or contractor will afford him no better, he is made the victim of force and injustice," (Leo XIII 1891, pg. 45). 
The defense of private property in CST originates in the writings of Thomas Aquinas, who cited three reasons that property was necessary for human life. First, because people will are more able to provide for themselves alone than in common with others; second, because, the human experience shows that people operate more effectively when they can focus on one thing for a length of time rather than many things simultaneously or in short order, and third, because a peaceful and just society is made possible when people are contented with a more simple life. However, there are common claims to property, making permissible even theft in times of great need (Aquinas 1911). The issue of communal property rights is at the frontier of this discussion in CST, as recognized by Pope Francis in Querida Amazonia, which calls for greater autonomy for the indigenous peoples of Brazil and Latin America (Francis 2020).

Objections abound from a variety of sources. Private property can be misused, critics will say. What are the limits to private property when it is abused? Medaille addresses this when speaking of economic rent, which can be defined as "an amount paid to a factor of production that is more than necessary to keep that factor in production in its current use," (2010, pg. 120). Rent is economically inefficient, for costs are passed on to consumers. Inefficiency inevitably costs consumers more, robbing the consumer of property due to poor stewardship of property by the economic actor. This gives way to the second abuse cited by Medaille, not using property at all except for purely speculative purposes. The illustrative example for speculation is the numerous offshore oil drilling leases held by oil companies in the US that are not in use in order for the companies to control resources, creating perverse incentives that artificially inflate prices, once again 
robbing consumers of inordinate wealth due to poor or corrupt stewardship of resources (Medaille 2010, pp.120-122).

Private property is a near-sacred right held by humans. Medaille defines the sacred nature thus: "Property acquires a sacred nature when it is associated with labor and serves as the guarantee that the laborer will get his just reward and not pay an economic rent for the privilege of living. Property is the guarantee that the worker and the investor will get their just rewards. As such, it will be the means to eliminate economic rents and to establish the economy on a sane, equitable, and workable basis," (Medaille 2010, 122). Property is almost sacred because it is a matter of the natural law. The natural law tradition holds a moralistic view of all aspects of life, seeing decisions and structures in terms of good and evil and is built upon the recognition of the relationship between persons and God. This has implications for the relationship between persons and the environment, as is demonstrated in Chapter 7 (French 2008, 15-24). The natural law tradition has been deeply influential on the view of private property. According to Pope Pius XI (1931), the right to private ownership of goods and the right to pass those goods on by inheritance must remain an intact right and not undermined by the State. The State cannot take away property rights from individuals as individuals exist prior to the State, as does the family.

What the Church means by private property is principally land and the means of production. Revisiting Aquinas, we see that property has a function rooted in Creation: that property, being Creation itself, is meant to support life, engenders good stewardship, supports an orderly society because if the majority of people own property they will be 
invested in a just society, which in turn enables a peaceful society, and reduces social strife (Spencer 2013; Aquinas 1901). Property ownership is an essential part of understanding what the Church teaches about human dignity, which includes the recognition that human life is more important than material goods (USCCB 2018). Property enables individuals and families to meet material needs without outside assistance, thus enabling persons to achieve the primary ends of life: spiritual union with God. Property is a critical means to an end, independence of material necessities so that material concerns do not achieve a disordered place of priority in the lives of people.

The objection is obvious. Socialists will make the argument that private property is the tool of oppression by the state or by capitalists. This view is expressed many times by the father of socialism and communism, Karl Marx, who said that private property is a system of rulership that promotes selfishness, leading to a condition where "each tries to establish over the other an alien power, so as thereby to find satisfaction of his own selfish need. The increase in the quantity of objects is therefore accompanied by an extension of the realm of the alien powers to which man is subjected, and every new product represents a new potentiality of mutual swindling and mutual plundering," (1844, pg.115). In short, Marx's Christian background (though thoroughly rejected) is on display in his comparing property and the culture it influences to sinful exploitation of one human by another for individual aggrandizement. And it is for this reason that the Church traditionally agrees, in principle, with the risks of greed and failure to be good stewards of economic resources, due to the ever-present threat of $\sin$ born from original sin. If this seems out of place in a discussion of economics, it is essential to remember that the Church does not separate 
moral theology from sociopolitical analysis.

In truth, the Church categorically rejects socialism and communism despite some lay and clerical movements being inspired by the ideology. On what grounds does the Church reject socialism? Beginning in 1849, Pope Pius IX condemned socialism by calling the use of Christian-sounding morality by socialist thinkers 'perverted teachings': "You are aware indeed, that the goal of this most iniquitous plot is to drive people to overthrow the entire order of human affairs and to draw them over to the wicked theories of this Socialism and Communism, by confusing them with perverted teachings." The Church recognized early in the life of socialist philosophy that the aim was the overturning of the social order, a point Leo XIII would build on when including socialism with nihilism and anarchism as ills that would lead to the ruin of society (Leo XIII 1878; 1881). Later, in 1884, Leo XIII would again build on the proposition that social ruin was inevitable under socialism by focusing on the tendency of socialists to be use demagoguery to build popular movements that fed off passions and a total lack of self-restraint, leading to lawlessness before tyranny (1884), which includes a destruction of the near-sacred institution of private property (1878).

Of chief concern for Leo XIII, beside from the anti-social and destabilizing nature of socialism, was the open hostility to religion and orthodoxy. In 1901, writing in the encyclical Graves de Communi Re, Leo writes "The harvest of misery is before our eyes, and the dreadful projects of the most disastrous national upheavals are threatening us from the growing power of the socialistic movement. They have insidiously worked their way 
into the very heart of the community, and in the darkness of their secret gatherings, and in the open light of day, in their writings and their harangues, they are urging the masses onward to sedition; they fling aside religious discipline; they scorn duties; they clamor only for rights; they are working incessantly on the multitudes of the needy which daily grow greater, and which, because of their poverty are easily deluded and led into error. It is equally the concern of the State and of religion, and all good men should deem it a sacred duty to preserve and guard both in the honor which is their due," (Leo XIII, 1901. para 21).

His successor, Pope St. Pius X, built on this condemnation of the attacking of the social order by beginning his attacks on socialism with the Catholics who sought to adopt and promote Socialism. Pius X called the attempts at crafting a Catholic utopia using socialism as "A mere verbal and chimerical construction in which we shall see, glowing in a jumble, and in seductive confusion, the words Liberty, Justice, Fraternity, Love, Equality, and human exultation, all resting upon an ill-understood human dignity. It will be a tumultuous agitation, sterile for the end proposed, but which will benefit the less Utopian exploiters of the people," (1910 para.42). Pius XI, after WWI, built on this condemnation, calling socialism incompatible with Christian truth (1931 para 111), because "Socialism.... cannot be reconciled with the teachings of the Catholic Church because its concept of society itself is utterly foreign to Christian truth," (ibid, para 117). This theory of human organization is incompatible because it "is based nevertheless on a theory of human society peculiar to itself and irreconcilable with true Christianity. Religious socialism, Christian socialism, are contradictory terms; no one can be at the same time a good Catholic and a true socialist," (Ibid. n. 120). Pius XII would later add that the reason for this is because 
socialists place the State above all else, either in theory or in practice, when the family and the Church are above all else in the rightly ordered society (Pius X11, 1939).

Pope John XXIII, considered by no scholars to be a conservative or a reactionary, built on this condemnation of socialism. "The reason is that Socialism is founded on a doctrine of human society which is bounded by time and takes no account of any objective other than that of material well-being. Since, therefore, it proposes a form of social organization which aims solely at production, it places too severe a restraint on human liberty, at the same time flouting the true notion of social authority," (John XXIII 1961 para 34). Later, John Paul II would later expand on this idea by stating that the understanding of human nature held by socialists was grossly erroneous due to the conception of the person as a cell within a social organism, with the good of the person subordinated entirely to the socio-economic organism. A person's free will is denied and his good is understood entirely in economic relations that strip the person of their dignity and right to private property (JPII 1991, para 12-13). Finally, Benedict XVI summarized the errors of socialism through the implications of a socialist society, namely that by having a state that controlled all economic aspects of society a social order was created that reinforced the secular notion that a person can live on bread alone, instead of the social order called for by the Church, which reinforces Christian relationships and the pursuit of a sanctifying virtue (Benedict XVI 2005).

The Popes of the $19-21^{\text {st }}$ centuries are not the only Catholics who condemned socialism without resorting to jingoistic nationalism. Inspired by papal writings, lay and 
clerical figures have contributed to this body of thought. Beginning with the late Fr. Vincent $\mathrm{McNabb}$, socialism is to be rejected because the properly ordered Christian life is one that imitates Christ, and Christ was born into a working family. Joseph, Christ's adoptive chaste father, was a carpenter by trade, and Christ's being born into working conditions has profound implications for the social order according to Fr. McNabb. "As the Land, and not the Town, is the social and economic ultimate, care must be taken not to organize the Land as we organize the Town, even as care must be taken in days of peace not to organize a people after the effective organization of days of war....Land work organized for markets and factory-made products will always fail. The only effective organization of the countryside where full Catholic life is normal will be the organization of LAND WORK AND HAND WORK," (McNabb 1941, 144). Life is not pleasant and is not about the pursuit of pleasure. Life is characterized by working to provide for the family and involves an intimate relationship with family, the land, and the community. For McNabb, the ideal Catholic society is agrarian, which may seem impracticable in the modern West. Modern society is characterized by self-imposed complexity and concerns of an urban/suburban/rural divide, but for McNabb and those who share his line of thinking, the modern West is on an unsustainable course. A return to the land was called for in the early $20^{\text {th }}$ century by McNabb and others. This view will be further explored in the chapter on the environment.

Economically speaking, decentralization in the form understood by McNabb was motivated by a love of God, family, the fatherland, the imitation of Christ, the pursuit of personal virtue, and a love of liberty understood in almost libertarian terms. "The Home is 
the Social Defense of Liberty and the Homestead is the Economic Defense of the Home," says McNabb, "Yet this liberty is not a man's physical and moral power to do what he would, but to do what he ought. The half-truth, and therefore heresy, of "self-expression" takes no lasting root on the land. But only on the land, with its easy direct access to the forces of nature, is there the normal possibility of that unselfish self-reproduction which is nature's counterstroke to "self-expression,"” $(2014,5)$. Typically, we understand liberty in strictly political terms but McNabb, repeating the teachings of the Church, understands the concept in such a way that liberty is intertwined socially, economically, and politically. Humans are a creature with duties, with duties to the family coming only second to duties to God (and those are not necessarily separate or in conflict). The need to provide for the family is the essence of economic liberty, and the essence of economic justice. If a person is free to provide for their family without being unduly hindered, then he is economically free. This precludes physical slavery or economic slavery (usury or wage slavery).

Liberty, in a Catholic sense, is about limitations, according to Chesterton (1929). This may seem paradoxical, but it illustrates the concept of widespread ownership of private property. It is in the ownership of property itself that this occurs, as well as in the family. This was understood both in political/economic terms and in religious terms as well; Chesterton uses the analogy of children on a playground, surrounded by walls free to play, until an alien force removes the wall, revealing sheer cliffs leading into a dangerous sea, causing the play to end (Chesterton 1918; Chesterton 1928). This analogy is an apt one for both understanding Church authority and, pertinent here, economics in the Catholic sense. The Church does not object to a regulated economy in the slightest, though wisdom 
is advised on the extent of regulation (invoking stewardship). Private Property that is widespread and limited in ownership size is the ultimate form of regulation, for it puts the family and the community in place as the regulator of the economic use of land and industry, not a faraway state.

Some critics will see this call for widespread private property and ask how the Church with its perceived vast wealth come into the picture. The response comes from the realm of apologetics backed by data: the Catholic Church, in a world that has a disordered relationship with private property, uses its wealth to run the largest network of schools, hospitals, counseling programs, orphanages, and other programs meant to alleviate the worst aspects of poverty in the world (Horn 2017). The Church provides more social programs than any government on Earth and does not require that recipients of this aide convert to the Catholic faith. One example is from the country of Kenya, which is examined in Chapter 7, where the Church operates eighty percent of the hospitals in the country (Nrue 2017). The Church uses this wealth to aid the poor.

Chesterton and his followers wrote a great deal about the need for private property to be widespread, all of it rooted in the writings of Pope Leo XIII, Aquinas, and the successors of Leo XIII. For Chesterton, private property was essential to the sustainable and just society because private property is essential to social sanity. Private property protects social sanity because the only society that can be both democratic and sane is the decentralized state with widespread property, which serves as the essential guardian against the worst tendencies of democracy, which is the mob rule that leads to 
socialism. Chesterton's confidante, Hilaire Belloc, put the role private property plays in defending the sane social order against socialism is brutally honest terms: "if you deny the human right to property, if you take the shortcut out of your present evils, by transferring control of land and machinery from the minority now holding it to the Public Servants, you are putting human life into the hands of those public servants in its entirety," (Belloc 2004, pg. 25). For the Church, private ownership of land and the means of production are essential to the preservation of human dignity and life by placing the control of life on the most fundamental level in the hands of individuals and families. As Belloc further elaborates in the same essay, "the right to property in material things is a moral right, attaching not only to the community, but also to private corporations, i.e., corporations other than the community, to families, and to individuals," (ibid). In other words, to paraphrase Pope Leo XIII (1884), the law should favor widespread ownership of private property.

On the most basic level, Chesterton echoes Leo XIII in decrying socialism because in the grand debate between liberal propertarian advocates and the socialists, the compromise position typically results in the good offered by liberal societies sacrificed for little of the good offered by socialism (Chesterton 1922). The counter charge is predictable: northern European states have created stable social democracies. This argument is overcome with facts regarding their reliance on liberal states (like the US) for defense that permits support of their increasingly expensive and massive welfare states, and that these states aren't truly socialist in that private property is still permitted (and that truly these were historically called 'welfare state liberal' systems until recently). 
The response from some Catholic theorists to the anti-Socialism of the popes and influenced by papal writings comes most noteably from the Liberation Theology school of thought. Gearon describes the emergence of liberation theology from about 1925 and into the 1930s as a time when the Church was focused largely on the emergence of totalitarian ideologies in Europe. "The position of the Church can be said to have varied from its identification with colonial powers, especially those of Portugal and Spain from the sixteenth century onwards, though the periods of emancipation in the early $19^{\text {th }}$ century to its ambivalent relation with the emergence of communist and fascist ideologies in the twentieth" (Gearon 2002 pp. 242-243). Two of the principal proponents of Liberation Theology were Gustavo Gutierrez and Leonardo Boff. Gutierrez's landmark work "A Theology of Liberation" posits the position of liberation theology in the framing of the abject condition of the poor and indigenous persons of Latin America, though the work is applicable to other parts of the developing world. The focus on the plight of the poor is central to this position, with at least some of the onus for responsibility being the defense of institutions that promote the private ownership of property and false charity that is given principally for political gain. "" Charity is today a 'political charity.. . . it means the transformation of a society structured to benefit a few who appropriate to themselves the value of the work of others. This transformation ought to be directed toward a radical change in the foundation of society, that is, the private ownership of the means of production," (Gutierrez 1973 pg. 109).

Boff, writing in defense of socialism from the position that socialism presents the best option for realizing community, states that socialism is fully compatible with the 
Catholic faith "because it places the social at the center of its organization it is more likely than any other system to bring the revelation of God- community into history. In real socialism, despite all the contradictions (the human price in its implantation, the urgency of the revolution of political freedom, etc.) we encounter the social integrating itself in the social historical process. It creates models of living together that are more social and more community oriented. The fulfillment of social-collective needs is better realized than in capitalism," (Boff 1989). For Boff and the other Liberation Theologians, the nature of private property ownership and the alienation it causes is the root cause of the ills of the poor, and as such must be controlled by the state.

To a degree, Boff and the likes of Pius XI, Leo XIII, Chesterton, Belloc, and McNabb would agree that capitalist structures of property ownership are at the core of the problem. The difference is to Boff that property needs to be more widely distributed among the people, not held in common by the state. A central conflict between the positions is the understanding of subsidiarity and solidarity, where the position of the popes places these values in a sort of balance where private property ownership is widespread among the people but can be regulated by a strong (if small) state, while the position of Liberation Theology envisions the state as working on behalf of the people, in a truly representative manner that quite frankly breaks with historical precedent. The historic failure of socialist regimes to respect the rights of persons and especially religious belief is recognized by Boff as a failure derived from the despotism of a vast bureaucracy that was directly linked to the corruption of the Soviet and Chinese states, with the solution being a socialist state that is much smaller in nature (Boff 1989). 
Boff describes liberation from despotism as central to liberation theology. This is the reaction to dictatorships of Central and South America in the twentieth century. Liberation Theology is a complex idea system that has been the subject of much scholarly analysis since the 1970s and cannot be given proper justice in this work. However, it is sufficient to say that the debate between Boff and his contemporaries and the Vatican led to a critical element of Catholic Social Teaching that remains under-developed in contemporary work from the popes and those inspired by their work: the preferential option for the poor.

John Paul II defines the concept, which had been under development by the Latin American bishops since the 1960s due to the influence of Boff and Gutierrez, as "an option, a special form of primacy in the exercise of Christian charity, to which the whole tradition of the Church bears witness. It affects the life of each Christian inasmuch as he or she seeks to imitate the life of Christ, but it applies equally to our social responsibilities and hence to our manner of living, and to the logical decisions to be made concerning our ownership and the use of goods," (John Paul II 1987 para. 42). According to this value, economic decisions should place the needs of the poor as a first concern to be addressed before others, in an attempt to alleviate endemic poverty that leaves generation after generation of peoples oppressed and without the political means to rectify the condition they live under.

By now it is clear that the Church has had a great deal to say about private property and capitalism. It is to capitalism that this turns next. 


\section{Capitalism}

The Church does not give a full-throated endorsement of capitalism by any measure. Long before Pope Francis condemned consumerism, the Church had been offering warnings against unrestrained capitalism (aka, laissez-faire) while simultaneously decrying socialism. Pope Leo XIII is again instructive here, as the source of these condemnations. Leo condemned the concentration of economic power in the hands of very few people, including the means of production and broader employment opportunities. In addition, Leo condemned routine abuses of economic power of his day, specifically the withholding of wages from wage-earners as well as the new forms of usury that had arisen in the new industrial towns in the form of high interest rates and the stores of the company towns that left wage-earners with few, if any wages (Leo 1891).

Pope Pius XI in 1931 wrote in his encyclical Quadragesima Anno, which marked the $40^{\text {th }}$ anniversary of Leo XIII's Rerum Novarum, that the context had changed to a society with growing wealth (despite the Depression) due to industrialized society. The

concern, then, should be that the poor and homeless should be one of the beneficiaries of the newly created wealth. Riches were not to be concentrated in the hands of very few people, which can be thought of as the application of subsidiarity, solidarity, and stewardship to the problem of wealth and poverty. One method was to ensure that wages were just, for the economic system was beginning to centralize private property ownership into fewer and fewer hands: "Every effort must therefore be made that fathers of families receive a wage large enough to meet ordinary family needs adequately. But if this cannot 
always be done under existing circumstances, social justice demands that changes be introduced as soon as possible whereby such a wage will be assured to every adult workingman,” (Pius XI 1931, para 71).

But this was not the endorsement of collectivist programs. Socialism was seen as an ever-increasing threat, bolstered by the ills amplified by capitalism that is divorced from humanity. The two are intertwined and described by Pius XI as inseparably linked: "Twin rocks of shipwreck must be carefully avoided. For, as one is wrecked upon, or comes close to, what is known as "individualism" by denying or minimizing the social and public character of the right of property, so by rejecting or minimizing the private and individual character of this same right, one inevitably runs into "collectivism,"' (ibid. \#46). Certainly this advocacy could not have been more critically timed, for the Depression was in its second year, and the specter of a long-crippled Germany and the rise of German National Socialism was becoming a more obvious threat, fueled by the failures of the markets and the state.

Writing in the aftermath of the collapse of the Soviet Union in 1991, Pope John Paul II published the encyclical Centesimus Annus, which marked the $100^{\text {th }}$ anniversary of Pope Leo XIII's Rerum Novarum. John Paul II reflected on the changes to the international economic system and the uncertainty provided by the collapse of socialism and the seeming triumph of laissez-faire capitalism. "The free market appears to be the most efficient tool for utilizing resources and responding to needs. But this is true only if you are able to buy and sell. Justice and truth demand that basic human needs should be met and that none 
should be left to perish," (John Paul II 1991, para 34). The pope reminded the world that the capitalist system is not the perfect and sole provider of solutions to needs and goods and argued that there was a role for the state and the society to address these needs (1991 para 40). The long-held value that earning one's bread and supporting the family was still not only a right but an obligation for every human being, and that any society that denied this human right was not one that was just (para 43).

The Church rejects libertarian notions of capitalism and socialism for the same reasons: the tendency to centralize private property into few hands is common to the two systems. The Pope differentiates the two systems when speaking about the former Sovietbloc countries and the economic development challenges they faced: "Can it perhaps be said that, after the failure of Communism, capitalism is the victorious social system, and that capitalism should be the goal of the countries now making efforts to rebuild their economy and society? ... The answer is obviously complex. If by "capitalism" is meant an economic system which recognizes the fundamental and positive role of business, the market, private property and the resulting responsibility for the means of production, as well as free human creativity in the economic sector, then the answer is certainly in the affirmative, ... But if by "capitalism" is meant a system in which freedom in the economic sector is not circumscribed within a strong juridical framework which places it at the service of human freedom in its totality and sees it as a particular aspect of that freedom, the core of which is ethical and religious, then the reply is certainly negative," (John Paul II, 1991, para 42). 
The essential feature of a just economic system is one that understands the freedom of persons to act to meet their demands and to enjoy the fruits of their labor in accordance to Catholic concepts of natural law and justice. Chesterton explores this further in his seminal work The Outline of Sanity, where he shows what difference, if any, exists between the two economic systems in terms of human dignity. Capitalism is, according to Chesterton, an economic system where a small class of property owners possess the vast majority of productive property, to such a degree that this condition requires the majority of citizens to work for this small class of owners. This is to be differentiated from private property, though capitalists and defenders of capitalism often conflate private property for capitalism because private property involves the use of capital.

If capitalism means private property, I am capitalist. If capitalism means capital, everybody is capitalist. But if capitalism means this particular condition of capital, only paid out to the mass in the form of wages, then it does mean something, even if it ought to mean something else.....Socialism is a system which makes the corporate unity of society responsible for all its economic processes, or all those affecting life and essential living. If anything important is sold, the Government has sold it; if anything important is given, the Government has given it; if anything important is even tolerated, the Government is responsible for tolerating it. This is the very reverse of anarchy; it is an extreme enthusiasm for authority. It is in many ways worthy of the moral dignity of the mind; it is a collective acceptance of a very complete responsibility. But it is silly of Socialists to complain of our saying that it must be a destruction of liberty. It is almost equally silly of Anti-Socialists to complain of the unnatural and unbalanced brutality of the Bolshevist Government in crushing a political opposition. A Socialist Government is one which in its nature does not tolerate any true and real opposition. For there, the Government provides everything; and it is absurd to ask a Government to provide an opposition, (Chesterton, 2002, pp5-6).

Perhaps ironically, for the proposed Catholic system to work requires a certain 
authority itself, traditionally thought of as the state and the Church working in concert in their respective spheres of influence to ensure that the people seek virtue and justice, as opposed to what de Tocqueville called 'enlightened self-interest.' For a truly free market to work the moral conditions of the people are required to be especially high. The concept of 'enlightened self-interest' seems ludicrous when examining the idea from a position that assumes Original Sin as a concrete reality that all people and social institutions must consider when seeking justice. Pope Francis spoke to this point at a talk given at the Pontifical Academy of Social Sciences in 2017, where he stated "The radicalization of individualism in libertarian and therefore anti-social terms leads to the conclusion that everyone has the "right" to expand as far as his power allows, even at the expense of the exclusion and marginalization of the most vulnerable majority. Bonds would have to be cut inasmuch as they would limit freedom. By mistakenly matching the concept of "bond" to that of "constraint," one ends up confusing what may condition freedom — the constraints — with the essence of created freedom, that is, bonds or relations, family and interpersonal, with the excluded and marginalized, with the common good, and finally with God," (Francis 2017, para. 12). Laissez-faire capitalism is traditionally understood in libertarian terms of enlightened self-interest that is successfully grounded in a civic nationalist virtue that recognizes that respect for others is essential to success (hence, 'enlightened'). This account is fundamentally secular and is divorced from the understanding of Original Sin that corrupts this relationship. The bonds Pope Francis spoke about in 2017 are undermined through the very unenlightened culture that emerges: a culture of rampant consumerism.

Why there is a need for economic authority rooted in religion is the obvious 
challenge. The concept of a truly free market rests on a sort of libertarianism, of a truly enlightened understanding of the need of virtuous behavior that mitigates selfinterest. Fulton Sheen, famous American archbishop and early televangelist, provides the answer, and merits quoting at length:

[Western Civilization], too, like the prodigal, is finding out to its own chagrin that in rejecting the authority of the Father's House, it did not escape authority, but it only substituted one authority for another, and an authority of a tyrannical kind, like the passions of the prodigal. Following the example of the prodigal, our civilization threw off all authority: First the authority of the Church, then the authority of the Bible, and finally the authority of religion and morals in the political, economic, and social order. This break with authority created a false sense of liberty such as the prodigal felt in the first wild moments of dissipation. Liberty was bound to be distorted once it was torn away from Truth and Divine Responsibility. Freedom became synonymous with doing whatever you pleased, whether it was good or evil, or believing whatever you pleased whether it was true or false. The result was that freedom degenerated into a form of "selfishness", expressed itself in such slogans as "be yourself", frowned upon all forms of restraint and sacrifice as contrary to the individual libido, and ended in what might be called the exaltation and glorification of the ego. But the modern man soon discovered that he is the slave of that which overcomes him, and that he really had not escaped authority. He had only substituted one kind of authority for another - in rejecting the authority of God, he became subject to the authority of Caesar. This came about because our civilization having lost the religious sanctions of authority, sought some obligatory organization as the sole means of escaping absolute chaos and degeneration, (Sheen 1940, pg. 114).

Sheen here is clearly rejecting de Tocqueville's 'enlightened self-interest.' It is worth very briefly revisiting that concept, for it has framed American socioeconomic life and, since the second World War, has been exported across the world in one form or another. In his travels across the United States in the 1830s, the French Aristocrat Alexis de Tocqueville observed strange paradoxes, chief of which was enlightened self-interest, 
which is understood today as a utilitarian or libertarian value that states that individuals who act to further the interests of others ultimately serve their own interests (de Tocqueville 2003, xx), and is today described in corporate social responsibility literature by the belief that individuals, groups, or businesses will do well by doing good(Nielsen 2005). In a practical sense, enlightened self-interest can be understood as an individual pursuing their interests (typically economic), with causal effects that benefit others, as long as those interests are pursued in accordance to some external sense of morality; de Tocqueville notes the presence of religion in public life and how this positively impacts or mitigates the worst tendencies that might emerge from the pursuit of self-interest (de Tocqueville 2003).

What the Church means by capitalism is summarized in the following quote from Chesterton. 'When I say 'Capitalism,' I commonly mean something that may be stated thus: 'That economic condition in which there is a class of capitalists roughly recognizable and relatively small, in whose possession so much of the capital is concentrated as to necessitate a very large majority of the citizens serving those capitalists for a wage,"' (Chesterton 1922, 5). Chesterton emphasized that others, including his critics, meant a variety of other things when speaking about capitalism and differentiated it from the mere ownership of property in a few hands that enabled what gets called wage slavery today but what Chesterton called "proletartianism": :the point is not that some people have capital, but that most people only have wages because they do not have capital,"(Chesterton 1922, pg. 5). This is the capitalism that the Church objects to: the rendering of people into a social status where the fruits of their labor are only paid to them in wages that do not enable them to become fully self-sufficient if they so choose to pursue self-sufficiency. The tendency of 
capitalism to centralize private property into the hands of the few marks it as nearly indistinguishable from socialism in terms of the relationship of property to the laborer. The alienation that Marx seemed so critical of as a fruit of capitalism is present in socialism as well. This centralization leads to the most alienating tendency of both systems, to which quoting Chesterton again is fruitful: "It is all very well to repeat distractedly, 'What are we coming to, with all this Bolshevism?' It is equally relevant to add, 'What are we coming to, even without Bolshevism?' The obvious answer is-Monopoly. It is certainly not private enterprise," (Chesterton 1987, p. 42).

\section{Labor}

According to Catholic Social Teaching, the issue of labor is fairly complicated but can be understood as both the labor of the individual and organized labor (both in the industrial sense and the labor union sense). Labor is understood as pointing towards human dignity. The United States Conference of Catholic Bishops states that "the economy must serve people, not the other way around. Work is more than a way to make a living; it is a form of continuing participation in God's creation. If the dignity of work is to be protected, then the basic rights of workers must be respected--the right to productive work, to decent and fair wages, to the organization and joining of unions, to private property, and to economic initiative," (USCCB 2018). The labor of humanity is the ongoing work of God's Creation, as Scripture says in Genesis that God places Adam in the Garden to work (Genesis 2), and later that humans are sentenced to toil for his food (Genesis 3), not as a 
lasting punishment for disobedience but as means of growth in virtue.

Pope Leo XIII has been cited already extensively in this work. The pope expressed the traditional teaching of the Church regarding labor in his encyclical Rerum Novarum [sometimes you italicize the names of encyclicals and sometimes you do not. I don't particularly care which approach you adopt, but you should pick one and stick to it so that you are consistent throughout the dissertation.] in a framing clearly applicable to the industrial economy of the late $19^{\text {th }}$ and early $20^{\text {th }}$ century, and certainly applicable to the contemporary economy: “[W]orking men have been surrendered, isolated and helpless, to the hard-heartedness of employers and the greed of unchecked competition. The mischief has been increased by rapacious usury, which, although more than once condemned by the Church, is nevertheless under different guise, but with the like injustice, still practiced by covetous and grasping men. To this must be added that the hiring of labor and the conduct of trade are concentrated in the hands of comparatively few; so that a small number of very rich men have been able to lay upon the teeming masses of the laboring poor a yoke little better than that of slavery itself," (Leo XIII, 1891, para XX). The rejection of concentrated power, money, and resources is a recurring theme in Catholic Social Teaching. In Leo's time, as today, the condition of laborers can be understood in terms of exploitation by economic and political elites

While the Church defends the rights of people to access and join labor unions, traditionally this has been understood in a model closer to the craft and merchant guilds associated with the Middle Ages. These guilds upheld social norms, morality, and in 
general served as another means for the fostering of virtue by ensuring that values expected in the broader culture to be included in the workplace as well strengthened the moral norms of society (Jones 2014, 53-71). The guilds upheld civic and religious institutions, with the complementary role of civics and religion on full display in economic activity. This often manifested in charitable works supported by guild membership, including social programs and activities that are today typically done by the state or by well-funded parishes (Jones 2014). Like any other aspect of life, labor is understood by the Church as being inseparable from religious life. The primary purpose of the labor union or guild included the spiritual growth of the person. Thus, the ideal union or guild would have a religious affiliation (Sparkes 2016).

The guilds are especially instructive for the modern economy because the guild ensured long-term employment through the rooting of their purpose in solidarity (Sparkes 2016). The guilds were mutual self-help organizations, where the needs of all involved were addressed with the understanding that the family is the cornerstone of society. Contrast this to the contemporary labor setting, with the growth of the 'gig economy,' temporary work, employees being seen as disposable 'human resources' by employers, and the likely impending collapse of the welfare state under growing burdensome debt. This debt, which makes the modern technocratic state and the subsequent administrative society possible, is built on a long-condemned practice: usury. 


\section{Usury}

While the Church's language against capitalism appears to be soft when compared to the language used to condemn socialism, the Church's condemnation of usury makes modern capitalism impossible. This adheres to Pope Pius XI's demand that society be constructed along the values of the Catholic religion, for usury is a threat to human freedom and dignity that runs afoul of the ideal economy based on solidarity and cooperation (Pius XI 1931). This is embodied by the words of St. Ambrose, "if someone accepts usury, he commits robbery, he shall not live," (Wiesner 1970, para.56). This is because, according to traditional understandings of interest, those who have accepted interest that cannot be paid in a reasonable time has accepted a form of slavery (Ihssen 2008).

The ordinary magisterium of the Church has had a great deal to say about usury over the centuries. The Fourth Lateran Council interpreted the Old Testament prohibition against charging any interest on a loan literally and threatened excommunication and denial of a Christian burial to those who engaged in the practice $\left(4^{\text {th }}\right.$ Lateran Council 1215 , Canon 67). Later, noted canon scholar Gratian defined usury as "to demand or receive or even to lend expecting to receive something above the capital is to be guilty of usury; usury may exist on money or something else; one who receives usury is guilty of rapine and is just as culpable as a thief; the prohibition against usury holds for laymen as well as clerics, but when guilty, the latter will be more severely punished," (Gratian, in McGrath 2008,332).

In the $16^{\text {th }}$ century, the Council of Trent placed usurers in the same category as robbers (Catechism of Trent 1934, 445-446). Today, the Church has controversially softened this 
stance, stating that usury is the charging of unreasonable interest, though the Church has yet to define what reasonable interest is (C Church 2438).

Pope Benedict XVI, in Caritas en Veritate, underscores the dangers of usury in the relationships between developed and developing nations as a new form of colonialism. In paragraph 65 , the pope offered regulation of interest and alternative mechanisms as a means to assist developing countries without resorting to usurious colonialism.

Both the regulation of the financial sector, so as to safeguard weaker parties and discourage scandalous speculation, and experimentation with new forms of finance, designed to support development projects, are positive experiences that should be further explored and encouraged, highlighting the responsibility of the investor. Furthermore, the experience of micro-finance, which has its roots in the thinking and activity of the civil humanists - I am thinking especially of the birth of pawnbroking — should be strengthened and fine-tuned. This is all the more necessary in these days when financial difficulties can become severe for many of the more vulnerable sectors of the population, who should be protected from the risk of usury and from despair. The weakest members of society should be helped to defend themselves against usury, just as poor peoples should be helped to derive real benefit from micro-credit, in order to discourage the exploitation that is possible in these two areas. Since rich countries are also experiencing new forms of poverty, micro-finance can give practical assistance by launching new initiatives and opening up new sectors for the benefit of the weaker elements in society, even at a time of general economic downturn, (Benedict XVI 2009, para 65).

The general objection to this from the capitalist class can best be summed up by libertarian economist Yaron Brook who, in his 2007 article in the Objective Standard, called the historic treatment of moneylenders as villains a crime against justice, defends money lending based on the societal benefits accrued. "By taking risks and investing their capital in what they thought would make them the most money, moneylenders and other 
financiers made possible whole industries — such as those of steel, railroads, automobiles, air travel, air conditioning, and medical devices. Without capital, often provided through usury, such life-enhancing industries would not exist-and homeownership would be impossible to all but the wealthiest people. Moneylending is the lifeblood of industrialtechnological society. When the practice and its practitioners are condemned, they are condemned for furthering and enhancing man's life on earth,” (2007). In short, modernity is made possible by the practice of money lending, so the objection goes. Thus, an attack on usury is an attack on modern economics, which libertarians and most capitalists would say is immoral, not on the grounds that there is a logically coherent argument for charging interest rates for loans but because the ends created by the modern economic system justify the means of attaining it, which in this case is the charging of interest rates, which at least in part are fuel for the economic system.

For the development specialist, the case against usury in the classical definition is simple to defend, based on the near-universal condemnation of the debt burdens the developing nations of the world labor under, all to the benefit of the governments and financial institutions of the developed world, most notably the United States (Johnson 1998). The issue of usury, or in more plain language, lending, is an issue of economic development and growth. Critically, many development theorists and policymakers have defended the practice of lending to some degree to fit as Carruthers states "a cold war mindset," which prized the opening of markets around the world for trade in the classic expression of the theory of liberal peace $(2001,99-112)$. 
This position has given rise to an area of economic analysis that dovetails well with Catholic Social Teaching, even if the conclusions drawn are incompatible. Certain strains of Marx-inspired economic analysis has used interest-lending with the developing world as a starting point of criticizing what often gets labeled 'neocolonialism,' in a use of language that will be familiar to those who have read the writings and public addresses of Pope Francis. The concerns of the various strains of Marx-inspired thought found footing within Catholicism under the banner of Liberation Theology, which was discussed in brief earlier, due in large part to the Catholic faith's in-built concerns for the poor. But secular strains of thought have long been critical of economic development funds given under the guise of aid to poor countries. One early study illustrated that classic Marxism failed to account for the lack of economic growth in third world countries leading to the predicted revolutions and instead had led to dependency on countries like the United States while the proletariat surged in population (Mandel 1980). A more recent study reinforces this notion of dependency on the developed world and its lending institutions when the predominant system of international development lending is referred to as "parasitic," with direct references to Marx's labeling of such systems of finance as "fictitious capital" that, as an institution, has consequences for hundreds of millions of people well beyond the shores of the lending nation (Harman 2010,65). "The suffering of many hundreds of millions as a result of the Volcker interest rate hike was a price worth paying to restore a relatively stable measure of value as far as US capitalism in its entirety was concerned -and helped cement its control elsewhere in the world," (Harman 2010, 2296). Even a surface glance at this statement makes clear that this arrangement, if accurately portrayed, is a violation of the 
principles of Catholic Social Teaching, as one nation controlling another or entire regions of the world is an overt violation of the Common Good.

\section{Consumerism}

An area of broad agreement with Catholic Social Teaching (aside from purely materialistic forms of liberalism disconnected with any concern for the community) is the subject of consumerism and its ill effects on people, family, and communities. In addition to the unnatural situation of money creating money from nothing (Jones 2014), the modern financial systems enables a consumerist culture that is part of the what the Church characterizes as the larger culture of death. Pope Francis has made consumerism a main target of his papacy. Consumer culture undermines all aspects of society by undermining the family and interpersonal relationships. In an address at St. Charles Borromeo Seminary in 2015, Pope Francis addressed this issue directly: "The result is a culture which discards everything that is no longer 'useful' or 'satisfying' for the tastes of the consumer. We have turned our society into a huge multicultural showcase tied only to the tastes of certain 'consumers', while so many others only 'eat the crumbs which fall from their masters' table'. This causes great harm. I would say that at the root of so many contemporary situations is a kind of impoverishment born of a widespread and radical sense of loneliness. ... Loneliness with fear of commitment in a limitless effort to feel recognized," (para.9).

What is consumerism? John Paul II defines consumerism as that state "when people are ensnared in a web of false and superficial gratifications rather than being helped to 
experience their personhood in an authentic and concrete way," typically done by substituting authentic human experiences through the rampant use of manufactured, virtual, or other goods for spiritual and interpersonal experiences (1991, para 41). Consumerism and the culture that results from institutionalized consumerism (consumer culture) leads to alienation that would be familiar to students and critics of Marx, by reducing the human worker to a machine (John Paul II 1991 para. 41). John Paul II describes alienation as a reversing of means and ends, where the essentials of subsidiarity and solidarity are undermined, which has spiritual consequences that damage society and the all-important spiritual ends of society.

One consequence of this alienation is the dehumanization of the impoverished. The poor are treated as 'collateral damage' and often are left behind in economic gains (Francis 2015). Some critics of Capitalism, such as GK Chesterton, suggest that this alienation is done purposefully, as enough wealth is provided to men to provide their voluntary enslavement while keeping those same men wanting enough to need to work. This is best illustrated in the participation in the consumer culture with the virtues in the capitalist system that Chesterton and Belloc both referred to as the Servile State: "Wait and see whether the religion of the Servile State is not in every case what I say: the encouragement of small virtues supporting capitalism, the discouragement of the huge virtues that defy it," (Chesterton 1917, 37).

Usurious systems have led to an economic reality that prevents broad ownership of private property and the creation of a system of labor that can only be described as perverse 
(Francis 2015, para. 43-61). The Church has always understood labor as activities that promote holy virtue, and as such has argued in support of religiously affiliated labor unions and guilds (Pope Leo XIII 1891). The perversity of the present labor system has many dimensions, the most salient of which is the tendency of separating men and women from their families in order to sustain debt-driven lifestyles; these troubling lifestyles are the product of consumerism, which requires the undermining of the family unit in order to make a reality.

A tangible problem with modern western economic systems built on debt and other forms of usury is the total unsustainability of these economic systems. The US national debt is, at the time of this writing, $\$ 23$ trillion, and personal debt in the United States is over $\$ 1$ trillion in credit card debt alone. Adding in the student loan crisis, the home foreclosure crisis, and the myriad of other forms of public and private debt in the United States alone, systems built upon usury are clearly shown to be unsustainable on the grounds of interest payments by themselves. Historically, the Church has argued against usury for a number of reasons, including the sterility of money and the unnatural tendency of money to create money in defiance of its nature; however, the Church has also argued that usury is sinful based on the tendency of usury to centralize property and wealth into very few hands, enabling the unvirtuous elites to centralize power and influence in society that runs contrary to the goals of a Christian society (Jones 2014).

A sustainable and just economic order in the Catholic vision is argued for in Quadragesimo Anno by Pope Pius XI, who argued for a reconstruction of economic and 
political life on the basis of Catholic values. This vision of an economic order is based on cooperation, solidarity, and subsidiarity. Chesterton, in What's Wrong with The World, describes this alternative vision of society, in universal terms:

The idea of private property universal but private, the idea of families free but still families, of domesticity democratic but still domestic, of one man one house - this remains the real vision and magnet of mankind. The world may accept something more official and general, less human and intimate. But the world will be like a broken-hearted woman who makes a humdrum marriage because she may not make a happy one; Socialism may be the world's deliverance, but it is not the world's desire.....The Church, however, knows that the disorganization of the world is largely due to the fact that it is not organized by any conscious acceptance of purpose other than the immediate interest of a capitalist class on the one hand, or a Communist class on the other hand. That is why the economic policy of the Church is constantly in opposition to both capitalism and communism, (Chesterton 2013, pp 78).

The alternative vision is one that can be described as 'post growth economics,' as the Church's condemnation of usurious consumer culture is a categorical rejection of the culture born from modern economics and their traditional centralized alternatives. Instead, the Church calls for the widespread distribution of private property, and often imagines a society of family owners. This is described by Dale Ahlquist, president of the American Chesterton Society, in comparison to modern American/English economics in a simple dichotomy. "It is said that it is convenient to get everything in the same shop. But in truth the monopolists' shops are only convenient to the monopolist. They concentrate business as they concentrate wealth-in the hands of fewer and fewer citizens," (Ahlquist 2003, 79). The stability and growth of the family relies on the ability of the family to be selfsustainable in partnership with their community, and communities in partnership with one 
another, flowing in a pattern that clearly leaves the family unit as the basis of economic activity and enables individuals and families to have maximized economic freedom to pursue their duties. This is fundamentally a vision of economics that is different from capitalism even if both claim a respect for private property rights, and it is different from socialism even if both claim a desire for greater leveling of property. The Church's vision is different because the ultimate good is not placed in the hands of material prosperity for its own sake; rather, the ultimate good is understood in creating a society that enables the cultivation of spiritual and civic virtues. 


\section{Chapter 6 The Environment and Humanity}

"The main point of Christianity was this: that Nature is not our mother: Nature is our sister."

- G.K. Chesterton, Orthodoxy (1908)

In 2015, Pope Francis released an encyclical that many observers called 'groundbreaking' even though the Catholic Church has had much to say about 'nature', or Creation, for many years. The encyclical Laudato Si brought attention to the Church's teaching on the environment and to the environmental crisis. The encyclical brought a renewed focus to Catholic organizations and laity to have a greater concern for the natural environment in accordance with Gospel values. This chapter will not focus on Laudato Si alone, but rather on the Church's teaching as a whole. Laudato Si represented a "systematic overview of the [environmental] crisis from a religious overview," (Martin 2015). As presented by Pope Francis and his predecessors, the teaching of the Church on the environment can be understood as a sort of mitigated quasi-anthropocentrism; it is not truly anthropocentric due to the focus on the relationship between humans and God and the concept of stewardship.

As in most areas of human inquiry, the Church often begins with St. Thomas Aquinas. The contemporary scholarly view is predictable. Benzoni (2005) argues that any sufficiently Thomistic approach to environmental ethics must be anthropocentric in its orientation, viewing animals, plants, biospheres and other such areas of human concern ultimately as instruments for human well-being. This builds on Halligan (1989), who states 
that Aquinas would not favor giving nonhuman creatures standing, as the Thomistic view would be based on an 'ontological view' of nature. According to this view, Thomism is an inherently sterile perspective, and thus the traditional theology of the Catholic Church is by extension anthropocentric and unfit for addressing the issues facing mankind and the Earth more broadly in an age of environmental crisis. One view sums this up concisely: "The sort of anthropocentrism we find in Thomas ... is one that centers creation around humanity only insofar as humans receive God's giving to creation," (Jenkins 2003, 405).

These perspectives are based on a sterile understanding of Catholicism. In this chapter, I attempt to illustrate the ontological grounding of human being as embedded in a created world whose stewardship has been entrusted to human beings on individual, family, community, national, and species-wide basis and is thus based in respect for authority and love of the Creator. This is rooted in theology, to which I will only address quickly, before exploring the principal offshoots of this view, which can be seen in the post-conciliar encyclicals of popes ranging from Paul VI to Francis, as well as the writings of figures associated with the Catholic Land Movement, like Fr. Vincent McNabb, and his friend GK Chesterton (among others) who offer a basis of understanding environmental justice as a relationship between human beings and God through the created order, with consequences for development. This has implications for the relationship between the moral virtues with the environment and other human persons from subsidiarity at each level, from the family, to the local community, to the state, the meso, and the supranational level. What are the duties that emerge? The Common Good is the overriding principal, with Stewardship clearly being critical to understanding the Common Good with the expanded view as 
described by Boff (2015), where human needs can be mitigated to a broader, multigenerational view that includes due respect for all of God's creation. This includes due respect for other human beings and the environment as seen in the concept of a nesting subsidiarity as described by Ostrom (1990) and Marshall (2010). This nesting principle describes a situation of governance where common pool resources are governed as necessary by multiple organizations that have an interest or stake in the health and sustainability of those resources. If combined with the New Public Management approach to imputing values into the governance process, which is the natural linkage with CST, then a way forward can be seen. The Common Good with the view due to the deicentric approach to sustainability that requires inclusion of the natural world as having its own dignity is a value-laden approach that address these problems, as long as it is remembered that these values are often in contention and often require a dialogue-based approach to finding out in the particular context which principles of CST are to take primacy in any given situation.

The Catholic view of the environment can on a surface level be described as 'anthropocentric' due to the understanding of the purpose of Creation and humanity: that all things are understood as having the purpose of supporting the salvation of souls. Superficially, this looks anthropocentric on its face, but in reality, the human person is understood as existing in a relationship with God and all things God created, including the Earth and all parts of the created order. This points to a relationship between the person and God. How humans treat the environment can be understood in the state of that relationship. Pope Benedict XVI describes this in a message to the World Health 
Organization in 2006: "The order of creation demands that a priority be given to those human activities that do not cause irreversible damage to nature, but which instead are woven into the social, cultural, and religious fabric of the different communities. In this way, a sober balance is achieved between consumption and the sustainability of resources," (Benedict XVI 2006, para. 7). The human right to development is qualified in that any development must not cause irreversible damage. Why does the environment receive this unqualified protection?

Benedict XVI again addresses this. In his 2007 letter to the Ecumenical Patriarch of Constantinople, he states "The relationship between individuals or communities and the environment ultimately stems from their relationship with God. When "man turns his back on the Creator's plan, he provokes a disorder which has inevitable repercussions on the rest of the created order," (Benedict XVI 2007, para. 3). That plan is the continued work of Creation through the working of the land as commanded by God in Genesis (see Genesis 2:15). A right-ordered society will see this continued working of the land in spiritual terms, with spiritual consequences. It will see work as having a fundamentally greater purpose than economics or even material sustenance. This is best understood in the concept of stewardship, which the US Conference of Catholic Bishops defines as "safeguarding material and human resources and using them responsibly are one answer; so is generous giving of time, talent, and treasure. But being a Christian steward means more. As Christian stewards, we receive God's gifts gratefully, cultivate them responsibly, share them lovingly in justice with others, and return them with increase to the Lord," (USCCB 2018). 
Catholic stewardship speaks to a complex relationship between human beings and the land that reflects filial love of God and continuing the work of Creation. In this, we can understand this relationship as less anthropocentric and more deicentric. Recall White's groundbreaking article "The Historical Roots of Our Ecological Crisis" (1967), which made the enduring claim that the roots of environmental degradation are rooted in the anthropocentric view of Christians. The error White and those inspired by White's work make is not distinguishing between the views of some Christians (especially non-Catholic Christians) and the teachings of the Catholic Church. The Catholic worldview is, when properly exercised, aligned on the deity first and the responsibilities that flow naturally from that understanding, not on human beings. This is a hard point for many to understand without being Christians themselves, as there is often a conflation of what one group of Christians believes with what all Christians must believe to be true. The essential element of this is that all actions are understood in relation between the person or the community and the Creator, who entrusted human beings to be stewards of the created environment. As such, the charge of anthropocentrism fails on the grounds that the properly ordered Christian worldview is centered on God, not the person. This is most readily understood in the hostility towards the modern world that is emulated in the Catholic Land Movement, which seeks to unite the human person to God through a holistic personal relationship with the land and an emphasis on localism. 


\section{Catholic Land Movement}

Fr. Vincent $\mathrm{McNabb}$, an Irish Dominican priest and thinker of the early $20^{\text {th }}$ century, distilled the writings of the popes of the late $19^{\text {th }}$ and early $20^{\text {th }}$ centuries on the topics of economic and social justice and addressed the issues arising in his day through his advocacy of the Catholic Land Movement. This movement can be characterized as a movement of Catholic laity who were driven to reject the increasing complexity of the industrial world of the day with a return to a simplified agrarian life lived in harmony with the land. Recalling the universal denunciation of both capitalism and socialism on the grounds of both systems centralizing ownership of property into the fewest hands possible, McNabb writes "The group of Catholics, Priests and Lay-folk, who are beginning an exodus from the famine to the possibility of ownership have, in fact, yielded to authority only as brought home by circumstances directly observable by themselves. They have been finally moved to act and to re-act not merely, or mainly, by the challenge from Rome but by the cry from the penury and sin of Glasgow, Birmingham, and London," (McNabb 2015). Citing Pope Leo XIII's encyclical Rerum Novarum, McNabb reminds his readers that the industrial revolution brought with it alienation from property ownership in urban areas, as well as a rising number of agrarian laborers who were also alienated from property ownership as private property (i.e., the land) became centrally owned in the hands of a very few oligarchs. These laypersons are not motivated by 'milk and honey,' a phrase borrowed from the Book of Exodus, but out of fidelity to the Catholic faith and a real desire to worship God. The disease of modernity is an idolatry of money and the goods produced by 
industrialism. The commandment "Thou Shalt Have No Strange Gods Before Me" is the foundation of all aspects of Catholic Social Teaching and is present in the understanding of the relationship of humans to labor and the person to the environment. This foundational, ontological understanding of the relationship between humanity and the environment and the consequences of disordered materialism connects with the concerns of environmental policy-makers and some activists who seek a means of changing the nature of the relationship between humanity and the environment without embracing a civilizationending policy program or agenda to achieve that goal. For example, Hailwood theorizes about the possibility of communal and private property ownership governed by the degree of anthropocentrism, where harm is analyzed in the inclusion of collective interests in the biosphere under considerations of economics and human need, where the needs of people are balanced against the preservation and flourishing of the biosphere (2015, pp.178-184).

Alienation is hardly a concept unique to Catholic Social Teaching. Emile Durkheim coined the term "anomie" to describe a social condition in which there is a disintegration or disappearance of the norms and values that were previously common to the society. Durkheim stated that anomie occurs during and follows periods of upheaval to the social, economic, or political structures of society. According to Durkheim this occurs most notably during periods when old values are cast aside socially, and new ones have yet to replace them. Thus, the concept of "normlessness" take shape (Durkheim 2014). Fr. McNabb, Belloc, Chesterton, and others were engaged in advocacy for Catholic Social Teaching in a time of upheaval. 
What Fr. McNabb's concerns speak to for the policymaker is the concept of natural limits, which are a source of an alienation that stems from the division of labor and the separation of humans from, in Christian terms, the garden. Literature from across the various fields of administrative theory and sociology are often concerned with the concept of alienation in bureaucratic settings (see Anderson 1970, and Tummers 2017 for quite different examples). This is a real concern in public policy, with the separation of humanity from nature being one often cited problem with anthropocentrism, including very real problems related to environmental protection, preservation, and development originating at the highest levels of the American political system, which in turn has wide-ranging effects on development efforts around the world (Bakari 2017, 5-11). The Catholic Land Movement, spearheaded by McNabb, sought to bridge the consequences of this divide (as understood in his time) through a return to a relationship between people and the land that would require cultivation of the land in a manner that would permit generations to thrive.

Father McNabb links the theological virtues and relationship with God to the economics and environmental principles of Catholic Social Teaching in the introduction to his 1942 collection of essays Old Principles and the New Order when he enumerates the central principles of his philosophy, which are the underlying principles of Catholic Social Teaching:

The first principle is that there is a God, our Creator, Whom we must love and serve; and Whom we cannot love and serve without loving and serving our fellow creatures. The second principle is that the Family is the unit of all social life; and that therefore the value of all social proposals must be tested by their effect on the Family. The third (psychological) principle is that from the average man we cannot expect more than average virtue. A 
set of circumstances demanding from the average man more than average (i.e. heroic) virtue is called an Occasion of Sin. The fourth (moral) principle is that the occasions of sin should be changed, if they can possibly be changed, i.e. they must be overcome by flight not fight. The great observed fact, of world-wide incidence, is that in large industrialized urban areas (and in town-infested rural areas) normal family life is psychologically and economically impossible; because from the average parent is habitually demanded more than average virtue......From this observed fact that the industrialized town is an occasion of sin we conclude that, as occasions of sin must be fled,... Flight from the Land must be now be countered by Flight to the Land. (McNabb 2015).

Catholic Social Teaching can be understood as a body of intellectual work that links philosophy, theology, and political theory into one body of work that offers an alternative to modernity. The contemporary world is often described by the popes as being intrinsically disordered, with obvious examples of this disordered nature of society manifesting itself in the social and economic relationships between persons. This has manifested itself in the relationship between human beings and the created world - that is, the environment. We see this in the environmental degradation that is the consequence of human economic activity. Any anthropocentric focus on the environment is based on the notion that human beings exist in relationship with God and were entrusted to be stewards of the created world.

\section{The New Catholic Land Movement}

In recent years, fueled by both a sense of alienation from the broader industrial and consumer culture and, paradoxically, the advent of the information age, there has been a renewed call for a Catholic Land Movement. This has clear implications for those doing 
the work of sustainable development. The New Catholic Land Movement is rooted in the observations of Pope Benedict XVI's call for a return to more traditional socioeconomic norms. "The Rural Family must regain its place at the heart of the social order," (Benedict XVI 2006 para.8). The emphasis on the rural family is based on the concept of integrated ecology, or the notion that the human person is best understood in the relationship that person has with his family, community, parish, and the world around them. The anthropocentric approach of secular conservative organizations like The Cascade Institute or The Discovery Institute isolates humankind from the environment and even from other human beings in a sort of bolstered individualism. The Church in all respects rejects any form of individual focus that divorces the individual from their duties to others and to God. This point was explored already in Chapter 4 on society and the person, but it bears repeating here due to the consequences of disordered individualism on the natural world.

There is a great emphasis in Catholic Social Teaching on the Natural Law. Thomas Aquinas defined natural law as the participation by rational creatures in the Eternal Law of God (Aquinas 1911, Q.94 A1-A5). According to the teaching of the Church that emerged from Thomas Aquinas's extensive work on the Natural Law, humans (and all of Creation) is by divine mandate willed to a particular end. Inanimate objects are bound by determinism, as they lack even a rudimentary form of will. Even human beings have an end, and this divinely purposed end is in perfect harmony with free will and the intelligence that separates humans from the animals. It is due to this intelligence that man has free will and is responsible for his conduct and is guided in that decision making in the laws that guide all of Creation. These laws are based on theology and human nature as well as in the 
nature of all things. All actions must be coordinated to the end that God had intended for humans. Anything that is in violation of that is a perversion and is constituted as a violation of the Natural Law. This interplay between humanity and the law is seen in relationships people have with the other human beings, with God, and with the Created world. Chesterton briefly describes the Natural Law by stating "[w]hat Christianity says is merely this. That this repetition in Nature has its origin not in a thing resembling a law but a thing resembling a will. Of course, its phase of a Heavenly Father is drawn from an earthly father," $(1908,387)$. That is, there is an ordering of the world in such a way that is not only understood as a series of rules but as a series of relationships, bounded together by duties. These duties are reflected in all aspects of Creation, and especially for our purposes, between human beings and the Created world.

Pope Pius XII linked the land to the broader body of Catholic Social Teaching through the embedding of the individual as subordinate to the family. "Your lives are rooted in the family-universally, deeply, and completely; consequently, they conform very closely to nature. In this fact lies your economic strength and your ability to withstand adversity in critical times. Your being so strongly rooted in the family constitutes the importance of your contribution to the correct development of the private and public order of society. You are called upon for this reason to perform an indispensable function as source and defense of a stainless moral and religious life. For the land is a kind of nursery which supplies men, sound in soul and body, for all occupations, for the Church, and for the State," (Pope Pius XII, 1946, para.3). A right-ordered relationship with the environment has consequences for society, as the ethic of working closely with the and in harmony with 
nature imparts virtue.

Pope Francis echoed this sentiment in 2015 when he addressed the president of Kenya in an official visit:

In effect, there is a clear link between the protection of nature and the building of a just and equitable social order. There can be no renewal of our relationship with nature, without a renewal of humanity itself. To the extent that our societies experience divisions, whether ethnic, religious or economic, all men and women of good will are called to work for reconciliation and peace, forgiveness and healing. In the work of building a sound democratic order, strengthening cohesion and integration, tolerance and respect for others, the pursuit of the common good must be a primary goal. Experience shows that violence, conflict and terrorism feed on fear, mistrust, and the despair born of poverty and frustration. Ultimately, the struggle against these enemies of peace and prosperity must be carried on by men and women who fearlessly believe in, and bear honest witness to, the great spiritual and political values which inspired the birth of the nation, (Francis 2015).

It is this relationship between persons, God, and the environment that illustrates the need for the concept of stewardship to be embraced by communities and the policymakers they work with.

\section{Stewardship}

Stewardship can be understood as the holding of something in trust so that future generations may benefit from what is being held. According to Thomas Aquinas, stewardship is conceptually tied to charity and almsgiving, and is understood in reference to our love of neighbor. We can really understand this through Christ's response when asked what the Commandments were: to love God, and to love our neighbor. Pope Benedict XVI 
explains this concept at it applies to environmental ethics and stewardship: "Human beings legitimately exercise a responsible stewardship over nature, in order to protect it, to enjoy its fruits and to cultivate it in new ways, with the assistance of advanced technologies, so that it can worthily accommodate and feed the world's population. On this earth there is room for everyone: here the entire human family must find the resources to live with dignity, through the help of nature itself—God's gift to his children—and through hard work and creativity. At the same time we must recognize our grave duty to hand the earth on to future generations in such a condition that they too can worthily inhabit it and continue to cultivate it," (2009, para.50). This may sound like anthropocentricism but it is critical to remember that, according to CST, human relationships with one another reflect the relationship a person has with the Creator and the obligations that imposes on protecting the created world (Catholic Church 2014).

Stewardship of the environment reflects this relationship with the Creator in how the created world is treated by human beings. Pope Paul VI, in his 1972 letter to the UN Secretary General Conference on the Environment, illustrates the nature of the relationship between humans and the environment:

Everything created by God is good," the Apostle St. Paul writes (I Tim. 4:4), echoing the text of Genesis that relates God's satisfaction with each of His works. To rule creation means for humanity not to destroy it but to perfect it; to transform the world not into a chaos no longer fit for habitation, but into a beautiful abode where everything is respected. No one can take possession in an absolute and selfish way of the environment, which is not a res nullius - something not belonging to anyone - but the res omnium - the patrimony of mankind. Those in possession of it - men in private or public life - must use it in a way that redounds to the real advantage of everyone. Humanity is certainly the first and truest treasure of 
the earth, (Paul VI 1972).

The work of perfecting creation is the participation of humanity in the continued development of the natural world with the purpose of preserving that natural world until the end of time and for human and natural flourishing. That flourishing is rooted in the divine commandment from Christ that people are to love their neighbor as themselves and in the concept of sacrificial selfless love that is the heart of stewardship. Again, Paul VI's groundbreaking letter to the UN Secretary General is instructive here:

Interdependence must now be met by joint responsibility; common destiny by solidarity. This will not be done by resorting to facile solutions. Just as the demographic problem is not solved by unduly limiting access to life, so the problem of the environment cannot be tackled with technical measures alone. The latter are indispensable, it is true, and your Conference will have to study them and propose means to rectify the situation. It is only too clear, for example, that industry being one of the main causes of pollution, it is absolutely necessary for the industrial operators to perfect their methods and find the means, as far as possible without harming production, to reduce, if not eliminate completely, the causes of pollution. In this task of purification, it is clear, too, that chemical research workers will play an important role, and that great hope is placed in their professional capacities. But all technical measures would remain ineffectual if they were not accompanied by an awareness of the necessity for a radical change in mentality. All are called to clear-sightedness and courage, (1972).

This "call to courage" is the recognition that the task of addressing environmental degradation is one that will require an admission by persons, states, and agencies that the issue is, in the parlance of public administration, a wicked problem, one of such complexity that simple solutions that undermine human dignity will not address the problem at all. Secular environmental policy developers have noted that environmental issues are firmly in the realm of 'wicked problems,' that is, those incomprehensibly complex and messy 
issues that are difficult to define, and even more difficult, if not impossible to solve (Rittel and Webber 1973).

The issue of wicked problems in the sustainable development literature is worth noting here, as it lends to the argument that the Catholic Church has much of substance to say regarding issues of environmental decay and societal complexities. For example, climate change is a wicked problem for numerous reasons, one of which is that ethical issues complicate the response by state and NGO actors, including that developing countries tend to be more negatively affected by the consequences of climate change than many developing countries (Balint 2012, 50). The ethical complexities of climate change are being recognized by an increasing number of people, including nearly half of young, college-aged persons in countries whose governments are most likely to sponsor environmental programs in the developing world (Markowitz 2012, 479-495). CST offers an important avenue of ethical and moral analysis that policymakers should consider as a means of addressing these wicked problems, as the moral framework of CST offers important principles for addressing the problems of the modern world.

And what is the problem? Like most problems of concern to the Church today, the problem is materialism and a disordered sense of the self. Today we call that sin 'consumerism,' which is the lifeblood of the economies of the interdependent developed nations. Block, Brueggemann and McKnight refer to the driving force of this culture as the 'Free Market Ideology,' which makes assumptions about human beings and human nature that has created an ontology of a world of scarcity, individualism, and competition (Block, 
Brueggemann and McKnight 2016). John Paul II called this the Culture of Death, tying the concept directly to abortion, war, and rampant use of human beings as a means to an end. Going in depth, John Paul II described the interconnected condition of issues as a 'multiplicity and gravity of social problems' that were a 'structure of sin'. The culture of death that emerges denies solidarity between persons and the world itself through a focus on efficiency that ruthlessly exploits people and the environment. John Paul II describes this in predatory terms: "In this way a kind of "conspiracy against life" is unleashed. This conspiracy involves not only individuals in their personal, family or group relationships, but goes far beyond, to the point of damaging and distorting, at the international level, relations between peoples and States," (John Paul II 1995, para 12).

The damage John Paul II spoke of is inflicted on the environment as well. In an address to seminarians in 2015, Pope Francis repeated this concept and connected it to the created world. "The result is a culture which discards everything that is no longer 'useful' or 'satisfying' for the tastes of the consumer. We have turned our society into a huge multicultural showcase tied only to the tastes of certain 'consumers', while so many others only 'eat the crumbs which fall from their masters' table'. This causes great harm. I would say that at the root of so many contemporary situations is a kind of impoverishment born of a widespread and radical sense of loneliness. ... Loneliness with fear of commitment in a limitless effort to feel recognized," (Francis 2015, para. 10). This loneliness is a dehumanization that separates humans from their neighbor, themself, and from God, leading to a destruction and exploitation of the environment with consequences that are both material and spiritual. Environmental destruction is already widely accepted as being 
a source of sociopolitical instability in the secular literature, with ample evidence supporting the conclusion that environmental degradation leads to or contributes to sociopolitical crises (Butzer 1983; Elliot 1996; Butzer 2005).

This returns the topic to stewardship. In an environmental context, stewardship is reflective of the relationship the person has with themselves, other human beings, God, and the created world. John Paul II said "The earth will not continue to offer its harvest, except with faithful stewardship. We cannot say we love the land and then take steps to destroy it for use by future generations," (John Paul II 1987, para. 7). The Compendium of the Social Teaching of the Church describes the issue of humanity's need to care for the environment as a common duty. "Care for the environment represents a challenge for all of humanity. It is a matter of a common and universal duty, that of respecting a common good, destined for all, by preventing anyone from using 'with impunity the different categories of beings, whether living or inanimate - animals, plants, the natural elements — simply as one wishes, according to one's own economic needs.' It is a responsibility that must mature on the basis of the global dimension of the present ecological crisis and the consequent necessity to meet it on a worldwide level, since all beings are interdependent in the universal order established by the Creator. 'One must consider the nature of each being and of its mutual connection in an ordered system, which is precisely the "cosmos"' $(2004,466)$.

These "mutual connections in an ordered system" are essential to understanding human's role in the created world. We can understand the view of the Church as one of humans being embedded in nature, not separate from nature. The conflict that exists 
between humanity and nature is the result of original sin and leads to exploitation of other men and of the created world, leading to further sin and destruction. Sin, in the most oversimplified terms, can be understood as a form of alienation: alienation from God, from neighbor, from the created world. Alienation enables exploitation, for alienation undermines the natural order by enabling a soft dehumanization or desacralization of all persons and things in our environment. All things become either an object of desire or a point of oppression for the person experiencing alienation. The philosopher Roger Scruton describes alienation as something that replaces natural beauty with "darkness and desecration," by reducing the sacred to an "object among objects", by removing the divine origins or purposes of something from its ontological purpose $(2009,317-325)$. To understand this in terms of the created world or the environment, recall that the purpose of the created world for humankind is to be the vehicle for our return to God. The theological underpinnings of the Church's teaching on the environment link humans inextricably to the Land, as far back as the first chapters of the Book of Genesis, where Adam is told that he will work the land by the sweat of his brow (see Genesis 2:15). It is through a mutually beneficial relationship between human beings and the land that people seem to be meant to be most at home. While those from some traditions of green politics may reject this suggestion, eco-tourism is a controversial approach to development that attempts to put local peoples in a more harmonious relationship with the environment. Ill-conceived development projects to promote eco-tourism can be seen as a blatant objectification of the land, though it does fit within the conservationist worldview. Eco-tourism, it can be argued, reduces the beauty of the created world into an object of commercialization, one of 
Scruton's "object among objects" that gets separated from a more integrated and holistic relationship between the local peoples and the land for mutual thriving.

Conceptually, alienation is rooted in modern philosophical discourse from numerous writers most famously in the writings of Marx. The Church since the time of Marx engaged in addressing this subject and continues to do so today as means of addressing the critiques of Marx without conceding the argument, John Paul II invoked alienation in Centesimus Annus, which marked the $100^{\text {th }}$ anniversary of Leo XIII's Rerum Novarum, when he stated that alienation was "...the loss of the authentic meaning of life" (1991, 41). Early in the papacy of Francis, the pope would invoke alienation again when he observed that we live in a world " "...marked by a 'globalization of indifference' which makes us slowly inured to the suffering of others and closed in on ourselves," (Francis 2013, para. 3). Alienation is a critical aspect of the world today, especially in the relationship between humankind and the created world, leading to any number of natural calamities, including environmental degradation.

\section{The Situation Today}

In Laudato Si, Pope Francis focused on the situation with environmental degradation today with a renewed focus, much like Leo XIII did in response to the growing crises of the Gilded Age. The focus of the Church's environmental teaching has always been on humanity, as the primary purpose of the Church is the spreading of the Gospel for the salvation of souls. This is reflected in the approach Pope Francis has taken with the 
environmental situation, especially in paragraph 101 of the document, which focuses on the human origins of the environmental crisis: "It would hardly be helpful to describe symptoms without acknowledging the human origins of the ecological crisis. A certain way of understanding human life and activity has gone awry, to the serious detriment of the world around us. Should we not pause and consider this? At this stage, I propose that we focus on the dominant technocratic paradigm and the place of human beings and of human action in the world," (2015, para 101). The culmination of human activity has at least partially resulted in the current situation. In this way, Francis's document is built on the foundation of Rerum Novarum and St. Thomas Aquinas's early commentary in de Regno, as the Social Teaching of the Church has always been understood as a critique of human activity and systems as seen through the lens of the Church's principal mission.

The call the Church puts forth in Laudato $S i$ is for a humanism understood as integral ecology. Again, quoting Pope Francis is appropriate: "We urgently need a humanism capable of bringing together the different fields of knowledge, including economics, in the service of a more integral and integrating vision. Today, the analysis of environmental problems cannot be separated from the analysis of human, family, work related and urban contexts, nor from how individuals relate to themselves, which leads in turn to how they relate to others and to the environment" (2015, para.141). This is a call for an integration of all conceivable fields of study, including theology and philosophy, to address the environmental crisis. To be clear, this is an almost alarmist statement by implication because it is built on the assumption that the situation is in keeping with the worst-case scenarios being proposed by mainstream advocates in the environmental field 
today. The result of this is of course a greater dialogue with the world, which is in perfect keeping with the call of the document itself.

One of the calls the Church makes today is for a recognition of greater interdependence between peoples in order to end exploitative human relationships that lead to exploitation of nature. A recognition of interdependence forces all people to think in terms of a common home, leading to the necessity of development of a common plan for addressing problems. An example of this in the secular literature is the call from the United Nations at the Rio+20 summit in 2012 for greater international cooperation in order to effectively address climate change and other environmental issues (UN 2012; Evans and Stevens 2012;). Another example of this is the research in the probable effectiveness of multilateral agreements for the reduction of $\mathrm{CO} 2$ emissions in such wide-ranging places as Germany, Indonesia, and Russia, with the aim of developing greater international cooperation on emissions and other wicked problems of environmental and economic policy (Fichtner 2002). This call from the Church and others for greater international cooperation requires a recognition that our technological innovations have been largely ineffective in dealing with the current crisis. Pope Francis goes as far as calling for a 'global consensus' for dealing with deep, systemic problems, because unilateral action by nations will not solve problems of inequality, poverty, and power disparities that lead to environmental catastrophe (2015, \#164). Part of this requires education of all persons to have a healthier relationship with the Earth and with one another (Francis 2015, \#218). This, in sum, is a clear call for greater international relationships with an eye towards a greater role for international agencies, as evident by the unprecedented praise for secular 
environmental organizations in this document: "We cannot fail to praise the commitment of international agencies and civil society organizations which draw public attention to these issues and offer critical cooperation, employing legitimate means of pressure, to ensure that each government carries out its proper and inalienable responsibility to preserve its country's environment and natural resources, without capitulating to spurious local or international interests," (Francis 2015,\#24). The task that the Church has yet to address is how this greater relationship between states and international authorities will be balanced or addressed by the critical value of subsidiarity, which in the context of international politics will be a safeguard of national sovereignty and freedom.

We return to alienation to understand Creation. In a Biblical sense, Humans have 'dominion' over the Earth (see Genesis chapter 2). Dominion was a form of responsibility for God's creation, which mean that human beings, as rational beings, are required to respect the Natural Law, which in itself requires the maintenance of a natural equilibrium in the created world, as "he commanded and they were created; and he established them for ever and ever; he fixed their bounds and he set a law which cannot pass away" (Ps 148:5b-6). This differs from some approaches to sustainability such as the biocentric approach, which treats environmental issues as a moral imperative apart from human needs (Rottman 2014) The Catholic approach is to integrate these needs out of love of God and love of neighbor. Christianity is fundamentally a religion based upon relationships, whether they be relationships between nations, individuals, communities, peoples, or human beings and the world around them (DT 22:4, 6). Pope Francis, in Laudato Si, states that the Bible has no place for a 'tyrannical anthropocentrism' that is unconcerned for other creatures 
(2015, para 66). This 'tyrannical anthropocentrism' is most notable in environmental degradation, which puts all of Creation at risk, as understood in the interdependent nature of ecosystems and biospheres. Pope Benedict XVI understood this when he decried environmental degradation in 2009: "The deterioration of nature is... closely connected to the culture that shapes human coexistence: when 'human ecology' is respected within society, environmental ecology also benefits...The Earth is indeed a precious gift of the Creator who, in designing its intrinsic order, has given us bearings that guide us as stewards of his creation. Precisely from within this framework, the Church considers matters concerning the environment and its protection intimately linked to the theme of integral human development," (2009, para. 51).

This 'integral human development' requires that human beings understand themselves as being embedded in a relationship framework with God, other human beings, and the Created world. This is diametrically opposed to the materialist ontological systems of liberalism and socialism, which place primacy in either individuals or in human organizations in a purely materialist context. Integral human development is a woefully under-developed concept in Catholic Social Teaching, likely due to having emerged mostly in the writing of Pope Francis and Benedict XVI. This development in Catholic Social Teaching can be seen as similar to the work of Leo XIII and his addressing of the issue of social alienation that was raised by Marx and others, where Francis and Benedict in the present day work to address the concerns of the biocentric school of thought while avoiding the areas that the Church would view as errors, including the lack of balance between the needs of human beings and the environment. This begins by joining with the biocentrists 
and deep ecologists in recognizing that the natural world has intrinsic value. In writing about what the goal of environmental research should be, Pope Francis says the following:

Ongoing research should also give us a better understanding of how different creatures relate to one another in making up the larger units which today we term "ecosystems". We take these systems into account not only to determine how best to use them, but also because they have an intrinsic value independent of their usefulness. Each organism, as a creature of God, is good and admirable in itself; the same is true of the harmonious ensemble of organisms existing in a defined space and functioning as a system (2015, 140).

The recognition of the Earth and its non-human denizens having value separate from the perceived utility they provide to humans is in line with the biocentric argument about the environment. Francis, in Laudato Si, is answering the criticism of the deep ecologists like Callicott, who seek to find a metaphysical basis for the intrinsic value of non-humans and the environment and the promotion of ecological literacy (Callicott 1980). It is this ecological literacy of Pope Francis that elevates the philosophical reasoning of CST from alienation being resolved through a mere recognition of reliance on the environment for human animals. Francis does this by imputing the recognition that all of creation is made by God, and as such is the bearer of dignity and rights independent from that of humans. The deicentric understanding of sustainability becomes important here, as it is through this relationship through God that we can have a right-ordered relationship with the environment that recognizes the dignity of these creatures independent of value the environment provides to human beings. The opening paragraph of Laudato Si reference the Earth as Sister and Our Common Home (Francis 2015, 1). The takeaway from Laudato $\mathrm{Si}$ is that the Earth is the common home of not only humans but also of all of God's 
creatures. Humans have been given caretaker status of the Earth, not absolute dominion to exploit the Earth for our selfish ends. Francis states this in response to both White (1967) and the deep ecology position when he states: "This responsibility for God's earth means that human beings, endowed with intelligence, must respect the laws of nature and the delicate equilibria existing between the creatures of this world ... 'he [God] established them for ever and ever; he fixed their bounds and he set a law which cannot pass away (Ps $148: 5 b-6) ",(2015,68)$. This broader definition of dominion as caretaker is meant to avoid the excesses of deep ecology, as Francis describes it, and seeks instead to find a balance point between the two positions of anthropocentrism and deep ecology (Van Tine 2017).

This balancing point between the two positions of anthropocentrism and deep ecology is important but it rests on recognizing the moral worth of all creatures, which is a major philosophical point for biocentrism. Individual organisms have moral value according to this view, and it is echoed by Francis in Laudato Si. The language of intrinsic value used by Francis to describe the natural world and all of creation is the same as that applied traditionally to humans, which recognizes both the intrinsic value of individual persons and the humans as a collective (Coughlin 2003; John Paul II 1995). This application of human dignity is at the heart of integral ecology, which requires a recognition that humans have a relationship with all of the natural world, and that the creatures of the natural world possess their own dignity apart from material utility to humans. Moral respect is due to any creature or object that possesses intrinsic value (Taylor 2011). Taylor provides essentially four tests of biocentrism that represent what Pepperman-Taylor calls a coherent worldview for biocentrism: that humans are members of the same Community of Life on 
Earth as other living creatures in the same sense and on the same terms; second, that all life on Earth is interdependent; third, all living creatures on Earth are "teleological centers" that are unique individuals pursuing their particular good in their own way; and fourth, that humans are not morally superior to other living creatures on Earth (Taylor 2011; Pepperman-Taylor 1995, 122).

It is important here to remember that the Catholic view and the efforts of Pope Francis in Laudato Si are not to present an argument for a Catholic biocentrism, but rather a deicentric view that serves as a bridge between anthropocentrism and biocentrism. Points two and three from Taylor's schema are clearly granted by Pope Francis throughout Laudato Si. The purpose of Laudato Si is to recognize formally in CST that all life on Earth is interdependent and that it has been the great hubris of humanity to act otherwise. Point three is reflected in the quoted section above where Francis states that all life on Earth has intrinsic value independent of human utility due to having been created by God (2015, 140).

Point one is where real disagreement with the biocentric position will come into the discussion. The human person is created in the image and likeness of God and endowed with intelligence for numerous purposes, one of which is according to Francis to be caretaker for creation. This is a higher calling than the rest of creation. Anthropocentric claims are based purely on the material needs of human beings. This calling from Francis is a higher calling in that materialism is going to have to be sacrificed to be a proper steward of creation. This will require a radical change of life for human beings as we collectively 
reevaluate our social and economic systems and take into consideration the needs of all life on Earth in addition to human needs so that all life may flourish as is its intrinsic right due to God-given dignity that all life possesses independent of material utilitarian reasons. This higher purpose is religious in nature. It can be termed metaphysical and ontological in nature, for it is concerned with the entire reason for human existence. This is reflected in Francis' work to update the Catechism of the Catholic Church to include ecological sins or sins against nature (Esteves 2019). In this framework, the natural world is the sister of humankind, not the slave of humanity to be exploited but to be protected and to be enabled to thrive.

The fourth point is objected to on similar grounds. Human beings possess an intelligence not seen in the natural world. This, however, does not give human beings license to exploit the environment. Humans are expected to respect the laws of nature and the equilibrium of nature, and the inherent laws that govern the natural world. It is human intelligence and free will that enables humans to either choose good or evil, to commit the ecological sins that destroy the equilibrium of nature. Francis declares humans to possess this divine spark of intelligence while at the same time declaring that the fields and creatures of the environment are imbued with the presence of God (Francis 2015, 68-100). This presence of a divine spark requires as a matter of faith that the natural world be respected by the faithful, and not to be merely an instrument for human needs but as something possessing its own divine value. This is not anthropocentrism but something else, for anthropocentrism assumes human supremacy (Crist 2017). This deicentric approach of Pope Francis is calling for the supremacy of God in human relations and 
requires that all of God's creation be treated as something truly special and deserving of honor and dignity, not only humans.

In the next and final chapter of this work I will use the work of various organizations that have taken Catholic Social Teaching and attempted to put them into practice through an approach called Catholic Action. Here, I will finish by focusing very briefly on a new Vatican office for the promotion of integral human development that illustrates the interwoven relationship between development, dignity, poverty, and the environmental crisis: The Dicastery for Promoting Integral Human Development.

The office of the Dicastery for Promoting Integral Human development promotes integral human development as seen in a Gospel worldview combined with the tradition of the Church's social teachings. The promotion of this endeavor requires relationships with the various national Conferences of Bishops, working in cooperation with those offices respects subsidiarity and solidarity (or, in the latest terminology, synodality) in order to uphold and promote values related to justice and peace as well as the care of creation. Perhaps most relevant, the dicastery studies the social teaching of the Church, with the aim of promulgating it widely and helping with its implementation, with the goal of organically creating a Catholic social order.

This new dicastery works in support of other organizations that do the groundwork of promoting Catholic Social Teaching in practice through the collection and analysis of data, using diocesan offices around the world to disseminate information. The central focus of the dicastery is, as it is for Catholic Social Teaching in general, "respecting the dignity 
of every person and affirming the values of justice and peace, and to helping people in need" (Francis 2019, Art. 3, para. 4). The spirit of subsidiarity is recognized in the focus on "establish(ing) relationships with associations, institutes and non-governmental organizations, including those outside the Catholic Church, who are committed to promoting justice and peace," (Francis 2019, Article 3, para. 5). The recent Amazon Synod and the document written by Pope Francis as a result of the Synod is an example of the work of this dicastery and its focus. In Querida Amazonia, Francis notes that Benedict XVI had previously called for the preservation of the Amazon region, but now couples that call with a call for the inclusion of indigenous peoples of the region into both the life of the Church and in concerns of environmental development. Francis specifically warns against an environmentalism that only is concerned with the environment and leaves out of the discourse the needs of the poor. The indigenous, according to Francis, need to be empowered after decades of marginalization by both activists and international business interests and the governments who empower both factions (Francis 2020). This represents a new, more forceful presentation of Catholic Social Teaching meant to address the concerns of Liberation Theology while avoiding those conclusions made by some of its activists that have caused controversy with the Vatican in the past, relying instead on the traditional values of Catholic Social Teaching re-presented with the concept of integral human development. It is these values, and the values promoted by Catholic Social Teaching broadly speaking, that is presented in the next chapter using organizations that have adopted these values and teachings in the work they do in the world. 


\section{Chapter 7 CST In Practice and Implications}

Catholic Social Teaching has been put into action in the real world of economic, environmental, and even sociopolitical development. While this work has largely been focused on the theoretical aspects of the writings of the popes and those they have inspired, there are numerous examples of the application of these ideas to the world where human lives are lived and the work of non-governmental organizations in the broadest sense has been done. To that end, the final chapter will be presented as follows: I will begin with an examination of Catholic Action, a papally-inspired and supported Catholic sociopolitical movement that inspired social and political change in accordance with Catholic Social Teaching. From there I will examine Mondragón Corporation, an entity in the Basque region of Spain that has survived multiple world wars, dictatorial regimes, depressions and recessions, and has weathered the economic storms of the past century, due in large part to Catholic Social Teaching being at the core of the corporation's values. Finally, I will examine St. Kateri Tekakwitha Center, which is based in the United States and its roots in CST and how it informs the political and environmental actions they promote.

Thus far, I have demonstrated that Catholic Social Teaching complements traditional approaches to various sustainable development schools of thought and practices by offering a possible third way between the dominant ideas represented in Biocentrism and what can be broadly called 'Green Capitalism' by both recognizing the primacy of some conception of property rights as well as the need to balance human needs with those of nature through the concept of stewardship and the relationship Catholics have between 
past, present, and future generations. This is embodied in the latest development in Catholic Social Teaching: integral human development, which, like the work of Leo XIII at the end

of the $19^{\text {th }}$ century that sought to balance private property ownership against the corruption of the Gilded Age, today seeks to promote international cooperation on wicked policy problems related to the environmental crisis by applying the values of subsidiarity, solidarity, the common good, and stewardship in the international arena. Moving forward, several examples will be provided, first with successes of Catholic Social Teaching applied to the actual world of practice, and second, failures from the realm of practice that could well have been successful if the core values of Catholic Social Teaching were applied.

\section{Catholic Action}

The purpose of Catholic Action was defined by Pope St. Pius X in 1905 as the laity operating in the public realm to 'restore all things in Christ,' which "includes not only what properly pertains to the divine mission of the Church, namely, leading souls to God, but also what we have already explained as flowing from that divine mission, namely Christian civilization in each and every one of the elements composing it," (1905, para.6). According to a papal letter by John Paul II in 2004, "[Catholic Action] stemmed from a "providential inspiration" and was a cohesive force that gave structure and an impetus to that contemporary trend of the "promotion of the laity" that was solemnly confirmed by the Second Vatican Council," (2004, para. 4). Catholic Action is laity-centered action in the public sphere that promotes real change inspired by the social teaching of the Church, and often inspires the creation of formal Catholic NGOs that adopt the moniker Catholic Action 
as part of the organization's name, as in the case of Catholic Action for Street Children in Ghana (Greene 2010).

The statement of Pius X, and the purpose of Catholic Action, is grounded in the belief that modernity has derailed itself from Christian civilization and, as such, has created the ills that many observers have noted upon, including alienation and institutionalized sin. The purpose of Catholic Action is to combat anti-Christian civilization using 'every just and lawful means' to repair 'the serious disorders' caused by modernity (Pius X 1905, para.7). The contemporary example of this is the organization Catholic Action for Faith and Family, based in San Diego, which seeks to "provide a network of resources and activities for clergy and laity to inspire them to reach out to others in an active way to defend [Catholic] values," (CAFF 2018). Catholic Action for Faith and Family (CAFF) has many initiatives, the most notable being the St. Gianna Physicians Guild. According to the St. Gianna Mission Statement, the organization's purpose is to:

Unite and encourage Catholic physicians, and those in the health care profession, to promote and defend Catholic principles in a public way by word and example, and to inspire sanctification in their lives. It seeks to use the influence and expertise of the medical profession to clarify and support sound ethics and morality in the practice of medicine and proclaim them in the public forum. As a way of promoting these values in the personal lives of the faithful, the Guild has a special devotional outreach to promotes and teach about the life and virtues of their patron, St. Gianna Beretta Molla, a dedicated wife, mother and physician who lived and practiced her faith in an exemplar way in the 20th century (St.Gg 2019).

The work of the St. Gianna Physician's Guild is often accomplished through legal advising and advocacy for medical professionals to defend their conscience rights on such 
controversial medical issues such as abortion, euthanasia, and contraception (StGg 2019). It is this marrying of the faith and works in practice into what has come to be called 'a seamless garment' by figures ranging from the late Cardinal Bernardin to Pope Francis that characterizes much of Catholic Action as a movement driven by the values of the faith. We can understand the application of Catholic Action to the medical field by noting its comprehensive "pro-life" approach that seeks to impact the lives of people from conception to natural death, including motivating the laity to act to support those in need (StGg 2019).

An example of Catholic Action is the historic informal association between the CIA and the Vatican and Catholic Action, with the purpose of preventing the rise of Sovietfriendly socialism in Italy after World War II. The work of the Vatican and the CIA was focused on preventing the rise of a pro-Soviet government in Italy by establishing the Christian Democrat party. The CIA funneled $\$ 1$ million to organizations like Catholic Action in Italy to elect "centrist" parties (CIA 1977, 204-205). The Italian Christian Democrats would win the elections of 1948 and hold power until the 1970s, which served to hold off the influence of the Soviet Union in Italy (Jones 2016; Wemhoff 2015).This partnership between the Vatican and the CIA would set the stage for the later association between the US and Pope John Paul II in the common work against the Soviet Union and Soviet-controlled Poland, culminating in the public relationship between John Paul II and Ronald Reagan.

Today, Catholic Action works as a confederation of international lay organizations that focuses on a variety of issues. In 2018, Pope Francis addressed the Italian chapter of 
Catholic Action and praised the activists for addressing the hygiene needs of the homeless in Italy. Pope Francis in 2018 addressed the activists and said that he appreciated their work and their drive to apply the tenets of the faith and the social teaching of the Church in the real world, and said that they were alleviating the suffering of the poor and mistreated children who had been left behind in the modern economy (Vatican 2018).

The stated purpose of Catholic Action is to build "a more just, fraternal, and supporting society" (Francis 2017, para. 2). This is accomplished through the action of laity in a variety of contexts. In addition to the overtly political work of Catholic Action in the years after the Second World War, Catholic Action groups have engaged in charitable works of mercy assisting the homeless, defending the rights of migrants, and lately, inspired by Laudato Si, working to preserve the environment and to defend the rights of the indigenous peoples of Latin America (Kerber 2018). The purpose of Catholic Social Teaching and Catholic Action is the institution of the values and principles of Catholic Social Teaching in the political and social systems of the world with the purpose of creating a more just and fraternal society (Pius X 1940; Lefebvre 1975; DeLallo 2005; Francis 2018). Catholic Action is explicitly ordered into the protection of human dignity and the promotion of social justice through concrete actions of charity, political action when needed, and advocacy for economic justice.

This rebuilding of a Christian society rests on the "principle that human authority represents the authority of God. They take to heart the interests of the people, especially those of the working and agricultural classes, not only by inculcating in the hearts of 
everybody a true religious spirit...but also by endeavoring to dry their tears, to alleviate their sufferings, and to improve their economic condition by wise measures. They strive, in a word, to make public laws conformable to justice and amend or suppress those which are not so," (Pius X 1905, para. 7). The work of Catholic Action differs from that of secular NGOs and other organizations in that these organizations apply the principles of Catholic Social Teaching to their activities, including establishing local organizations dedicated to alleviating poverty through the establishment of social program operations and even assisting with the establishment of microfinance lending in countries around the world, including controversially in Mexico under the name Gente Nueva in 1990 by locals inspired by a visit from Mother Theresa (Bateman 2010).

While the concept of a 'seamless garment' in Catholic Social Teaching overtly emerged in the 1980s with the work of Cardinal Bernardin of Chicago, conceptually the 'seamless garment' had been promoted by Catholic Action through work connecting issues of life, human dignity and economics in various actions from assisting in educating the poor in Africa to providing interest-free loans in Mexico (Green 2010; Bateman 2010). If understood in the model of Catholic Action, we can see the total integration of Catholic Social Teaching in the economic, sociopolitical, and environmental sense in the work of several different organizations that are lay focused today. It is to one those organizations that will be the focus next.

An example of lay focused work inspired by the principles of Catholic Action is the American Catholic non-profit organization Unbound, which sponsors support of more than 
three hundred thousand children and families in eighteen countries (Shahriari 2011). The Mission of Unbound is an example of what a Catholic Action-inspired organization might look like in practice:

Unbound's mission is to walk with the poor and marginalized of the world. We provide personal attention and direct benefits to children, youth, aging, and their families so they may live with dignity, achieve their desired potential and participate fully in society. We invite people of goodwill to live in daily solidarity with the world's poor through one-to-one sponsorship. We build community by fostering relationships of mutual respect, understanding, and support that are culturally diverse, empowering and without religious or other prejudice. Grounded in the Gospel call to serve the poor, Unbound is a lay Catholic organization working with persons of all faith traditions to create a worldwide community of compassion and service. (Unbound 2020)

One example of work sponsored by Unbound was the case of the Lansing (Michigan) Youth Mission and its trip to Guatemala in 2015. The youth group spent a week in country, learning from and assisting Unbound staff in the construction of a house for a young boy and his grandparents using funds donated by laypersons to the Lansing Youth Mission directly (Correspondent 2015). The volunteers worked directly with local laborers and with the family. Youth volunteers report having lived among the local population and observed the way that the locals lived, which is a far different lifestyle and standard of living than students from an American community. This not only represents the solidarity of the organization and its volunteers and partners with one another and with those they serve, but it also reinforces the concept of solidarity in the lives of the volunteers and organizations by placing those who do this work in close contact with those they serve. Volunteers worked with local experts and craftsmen to build the home of the family, as well 
as observer the way of the life of that family and the community they live in, which will serve to influence the lives of the volunteers and their understanding of the world and their role in it for the rest of the lives (Correspondent 2015).

Originally founded as The Christian Foundation for Children and Aging (CFCA) by the Hentzen family in Kansas in 1981, Unbound funds scholarships, disaster assistance, micro-financing, small business loans and water and sanitation projects in their sponsored communities (Denzer 2015). While Mission Statements formally outline the purpose of organizations that fulfill legal and organizational purposes, the views expressed by the founder of an organization or its president are often illustrative of the purpose of the organization's work. Prior to his death in 2013, Unbound founder Bob Hentzen stated of the renaming of CFCA to Unbound that he wanted a name to reflect the real purpose of the organization. "You know, we walk side-by-side with people who dream of freeing themselves from poverty, as they strive to achieve self-sufficiency and build strong communities. Our new name sums up our work." (Denzer 2015). Unbound's president stated at the time that that the name change was meant to express the purpose of the organization more clearly. “A bunch of initials doesn't convey anything.... What Bob wanted was a single word capturing the essence of Catholic social teaching and empowering the poor. One word closely related to Catholic theological values, compelling and emotional: something people can 'sign on to"” (Denzer 2015).

In practice, the name Unbound is a clear reference to the sponsorship model of direct support and the ecumenical nature of its partnerships, which often include 
collaboration with non-Catholic organizations. An example of the sponsorship programs are Unbound's "Hope for a Family" sponsorship program, which aims to help families living in extreme poverty by connecting them with sponsors in the United States. Individuals and families can sponsor families in the developing world through a required \$36 monthly commitment, which helps fund basic necessities as well as livelihood programs to help families become self-sustaining (Unbound 2020; Marketwire 2011). Marketwire, a non-profit watchdog organization, describes the Unbound sponsorship model as being divided into three types:

Community Projects -- Some child sponsorship organizations pool the funds from individual sponsorships to help support larger community projects like the development of new schools or hospitals. These organizations also might distribute general goods like food or clothing to entire communities. Direct Support -- Organizations such as CFCA connect individual sponsors with children in need, providing them and their families with resources such as food, education, vocational training and micro-loans. Third-Party Support -- A few organizations use the sponsorship dollars they collect to support local groups or organizations that already provide resources for people living in poverty, including schools, churches, shelters and food banks. (Marketwire 2011).

Solidarity beyond the immediate community of the donor is fostered through the sponsorship program, which provides the donor the opportunity to offer encouragement and support for their sponsored families through the exchange of letters and photos, which in turn fosters the development of friendships (Unbound 2020). "They also may choose to travel on Unbound awareness trips to meet their sponsored friends, learn about their lives and see how contributions are used. Benefits and services provided through sponsorship are personalized according to the needs of the family and may include: food, school 
uniforms, school supplies, tuition or other school fees, clothing, housing repairs, medical and dental care, livelihood initiatives, literacy training for adults, Christmas and birthday celebrations and social outings and assistance for the elderly," (Unbound 2020).

The principles of Catholic Social Teaching provide organizations the opportunity to promote greater human interconnectivity, regardless of the religious affiliation (if any) of the organization that adopts them. It is clear that solidarity, which is often overlooked by proponents of CST, is promoted by Unbound, which enables it to assist in the development of a more just, peaceful, and sustainable world. This is reminiscent of the challenge issued by Pope Francis in December 2019 to the delegates from the Italian Catholic Action Association upon their papal visit, where Pope Francis challenged the activists to be "bridges where they lived" and to recall that Christ "recomposed the whole human race in unity," (Francis 2019, para. 2). Organizations like Unbound are demonstrating the fruit of this approach by connecting the global North to the global South through programs designed principally to elevate the poorest people out of abject poverty while connecting the donors and sponsors to the families in the clearest example of a solidarity that crosses borders.

\section{Mondragón}

The Mondragón Corporation is a collection of cooperative economic entities operating in the Basque region of Spain. Founded on the principles of Catholic Social Teaching by a group of six engineers inspired by a Catholic priest, Fr. Jose Maria 
Arrizmendiaretta in 1956, the enterprise has been described by researchers as "engaged in an exciting attempt to reconcile modern industry with social justice and democracy," (Molina and Miguez 2008, 288; Oakeshott 1973). A for-profit corporation, Mondragón promotes Catholic social teaching through the clear embracing of the principles of CST it in its best-practices and in organizational policies. Mondragon's revenue in FY2017 was 12.11 billion euros, representing the fruits of ninety-eight enterprises covering a wide range of shoe production to cooperative banking (Mondragon 2019).

Catholic Action was highly influential in the founding of Mondragon, with Fr. Arrizmendiaretta allying himself with several young businessmen from the local chapter of the organization in the Basque region. The Catholic roots of the business remain an important part of the organization's identity today, which aided the organization in surviving the turbulent economic environment of Spain in the 1970s (Voinea 2012). Fr. Arrizmendiaretta sought to establish a Catholic business in cooperation with the local bishops that was firmly rooted in CST (Herrera 2003). According to Herrera (2003), "Mondragón responds to a calling to holiness as an organization that competes successfully in a global market economy while maintaining its congruence with Catholic social thought." These principles and best practices are embodied in ten key principles for the organization, which according to Ormaecha, "balance individual, organizational and community needs" (1993, 164). These principles are: open admission, democratic principles, sovereignty of employee's work over capital, all workers are entitled to an equitable share of profits, recognition of the subordinate character of capital, participatory management, payment solidarity, inter-cooperation between cooperatives, social 
transformation, universal nature, and education. Each will be examined in brief.

The Mondragón principle of Open Admission is understood as the company being open to all who can perform an available job. As a company founded in the Basque region of Spain, complete with the serious ethnic issues that comes with, this principle seeks to rise above the ethnic and nationalist tendencies that have been a constant social factor in Spain since at least the time of Franco, if not before. Discrimination on the basis of religion, political affiliation, race, gender, age or socioeconomic status is prohibited, which reflects the long tradition of anti-discrimination contained in Catholic Social Teaching. This was best reflected most recently in John Paul II's address to the UN against apartheid in South Africa. Given in 1984, the pope cited St. Paul in calling for an end to racial discrimination, as well as social discrimination in any form. John Paul II said discrimination "still disfigures our age. It denies the fundamental equality of all men and women, proclaimed by the different Declarations of the United Nations, but above all rooted in God" (1984, para.2). While the Church has always affirmed that men and women are not equal per se but complementary in nature, it has opposed unjust discrimination for centuries. Pius XII described unjust discriminatory practices as a violation against both charity and human solidarity. Pius XII termed such practices to be an error "today abundantly widespread, is disregard for the law of human solidarity and charity, dictated and imposed both by our common origin and by the equality in rational nature of all men, whatever nation they belong to. This law is sealed by the sacrifice of redemption offered by Jesus Christ on the altar of the Cross to his heavenly Father, on behalf of sinful humanity" (1939, para 439). 
The principle of Democratic Organization states that the workers are owners, and the owners are workers, where each cooperative is managed by a system of 'one person one vote.' In Rerum Novarum, Leo XIII called for greater power in the workplace for workers in order to protect human dignity. The principle of Democratic Organization answers Leo XIII's call for greater unionization of workplaces without the need of formal unions, as each cooperative is operated under the voting influence of the workers themselves. Each employee shares in ownership of the company, not in the manner that they buy shares in company stock like other companies in the western world, but in the manner that each major decision undertaken by the company must be approved by the employees directly. This places the power of preserving the company and distribution of its profits into the hands of the employees themselves. This is a new understanding of organized labor, with the recognition that strong organized labor is the only reliable protection of the rights, safety, and well-being of workers and their families (Leo XIII 1891). This different understanding of organizing labor is differentiated from the contemporary paradigm of labor, where labor exists in a conflict with the owners of property. Instead, what is sought and, successfully found in Mondragón, is an affinity between business and workers found through shared ownership and shared power in decision making processes (Peterson 1995).

The principle of the sovereignty of employees' work over capital is the cooperative principle of Mondragón. When workers join the Mondragón cooperative, they become owners after making capital contribution at the end of the initial trial period. All workers are entitled to an equitable distribution of profits and is made possible by the use of the return on saved or invested capital not being tied up in surpluses or losses of profits, which 
does limit the return. However, this return on profits goes first to the workers, not to shareholders. This principle addresses the dangers of what John Paul II called the "idolatry of the market" by attempting to place the needs of workers over investors who do not have the same interests in the success of the employer as do those workers who themselves share in the ownership of the company, as the needs of the workers are tied symbiotically to the success of the operation (1991, para.40). This principle of Mondragón illustrates what John Paul II expounded upon when he called for a deep change in the economic system. "A change of mentality is needed, no longer seeing the poor as a burden, or as intruders trying to profit from others, but as people seeking to share the goods of the world so that we can create a just and prosperous world for all," (1991, para 28). Workers taking ownership of the workplace provides a share in private property, protects the autonomy of the worker, and thereby strengthens the family unit. This is further seen in the principle of the recognition of the subordinate character of capital, which places capital in its rightful places a means, not an end in itself. Capital is used to create jobs in Mondragón.

Worker ownership necessitates the principle of Participatory management. Workerowners participate in decision making and the management of the cooperatives. This implies development of self-management skills. Formal education and adequate information is provided to improve worker-owners' ability to participate competently in decision making. Worker ownership directly leads to the next principle, Payment Solidarity. Worker compensation is regulated both internally and externally. Internally the difference between the highest and lowest paid job is agreed upon by worker decision; externally, worker wages at competing companies influences Mondragón worker pay to 
maintain parity.

The Mondragón guiding principles support social sustainability through the networking of cooperatives into groups that pool profits. This enables the organizations to absorb worker-owner transfers, and to coordinate mutually beneficial efforts. Mondragón associates with other Basque cooperative organizations to promote the cooperative model. Thus, this principle leads directly to the principle of Social Transformation, whereby Mondragón cooperates invest a majority of their profits in the creation of new jobs. Funds are also used in community projects and in institutions that promote the Basque culture and language. Despite this, the Mondragón principle of Universal nature is maintained, where the company proclaims its solidarity with other cooperative movements, with those promoting economic solidarity and with those companies and organization promoting peace, justice and human dignity, especially with those organizations in developing countries. To accomplish this, Mondragón adheres to the final principle, Education. Mondragón cooperatives support economically and technically to basic, professional and cooperative education in order to realize the aforementioned operating principles, thereby helping sustain the organization moving forward.

Mondragón has, as a consequence of these principles rooted in Catholic Social Teaching, experienced long term stability and reinforced a robust and growing sense of Basque national identity, much to the chagrin of the Spanish government, as well as provided a center of economic stability in an economically unstable Spain. This has been done in part at least by the rejection of the contemporary understanding of capital, 
centralization of the means of production in both dominant political and economic theories in practice today, and in placing human solidarity and dignity as a centrally important value in determining action for the company. Mondragón represents a good example of both economic and social sustainability and justice in practice.

These principles could be expanded in the developed world through economic development programs designed to resuscitate ailing economies by modeling the successes of Mondragón and incorporating the guiding principles where applicable. Some companies may find it easier than others to adopt these values. One such example would be Winco Foods, an employee-owned grocery chain based out of the Pacific Northwest that is rapidly expanding across the western United States. At present, Winco Foods is $80 \%$ employee owned, with employees who have remained with the company after five years entering into the employee-ownership program that invests corporate profits into employee retirement funds (Zwiebach 2013). This is the Mondragón principle of sovereignty of work over capital, but Winco Foods could do much more. Winco is faced with a question that the employee-owners of the company must answer, which is whether the vision for the future of the company is as a single, large entity that competes with Walmart, Safeway, Kroger, and the like, or if the company should fully embrace the Mondragón approach of splitting into smaller entities. Winco may find itself with a competitive advantage by becoming a more cooperative business with regional identities under the umbrella of a national brand by embracing this principle, which would then allow the principles of Democratic Organization and Participatory Management to be implemented in their stores, which will then foster a greater identification of the employees with the company, which in turn will 
enable stabilization of Winco Foods during turbulent economic environments.

The development of economic cooperatives has long been noted as being key to attaining the Sustainable Development Goals set by the UN and various treaties. Economists and environmentalists recognize as a wicked problem the issue of raising the standards of living in the developing world while simultaneously reducing the carbon footprint of those same peoples. One cited example is that of cooperatives in the developing world, with agricultural cooperatives allowing small-holding farmers "to achieve economies of scale in production, processing marketing, and sales," (Parikh 2009, 57). Included in this are financial cooperatives (including smaller scale operations such as informal entities, like mutual liability microfinance groups, that "aggregate capital, conduct transactions, and distribute monitoring costs to enable convenient, affordable access to financial services," (Parikh 2009, 57).

Microfinance cooperatives are a prime example of the success of democratic principles and solidarity applied to private enterprise. The term microfinance covers the broad range of small-scale financial services targeting low-income individuals worldwide. In the 1990s, microfinance replaced the terms microcredit or microenterprise as savings came to be recognized as an important aspect of programs (Rhyne 2001). A focus of microfinance enterprises in Bolivia, India, and elsewhere in the developing world has been to lift poor women out of abject poverty. This is accomplished by creating opportunities for economic advancement through the creation of a social safety net that facilitates economic activity (Bee 2011). As of 2008, there are over one million microfinance 
cooperative societies in India, spurred on by the central government to promote the goals economic development. Each of these institutions is tiny, with a democratic and participatory system of deliberation that is reminiscent of Mondragón's governance model (Karmakar 2008, 159).The examples of Bolivia and India are models for the developing world to follow that enable economic development that promotes independence for families and single women and allow for the development of economic systems that are not enslaved to the international system of neoliberal capitalism that is highly centralized.

\section{St. Kateri Center}

The application of Catholic Social Teaching to the environment is a relatively new addition to the centuries-long tradition of teaching and action on socioeconomic issues. While this work in the literature of the Church is relatively new, that has not prevented lay organizations from forming to address issues related to what Pope Francis has come to call 'integral ecology.' One organization doing work on the environmental issues discussed by Popes Francis and Benedict XVI is the St. Kateri Center, which is based out of the Archdiocese of Oklahoma City, in the United States. Named after St. Kateri Tekakwitha, a Native American Catholic convert woman who suffered martyrdom at the hands of other Native Americans, the organization is dedicated to addressing issues related to the environment and ecological education and conservation in line with the social teaching of the Catholic Church. This is accomplished through the promotion of several programs designed to teach integral ecology to Catholic laity in ways similar to that of Catholic 
Action. Integral ecology adopts this model to environmental concerns and applies that logic to what liberal societies consider the private realm: the home.

The St. Kateri Tekakwitha Center encourages traditionally private-sphere action through its Habitats program, whose purpose is:

To inspire Catholics and others to restore backyards, gardens, farms, parks, vacant lots, forests, grasslands, streams, wetlands, and Catholicowned lands into healthy habitats for people and wildlife. We do this close to home, where we live. The Saint Kateri Habitat Program encourages individuals, parishes, schools, religious orders, and working landowners to restore their natural homes in a way that praises God and fosters a greater connection between people and nature. With a special focus on Catholic faith and social teaching, the Saint Kateri Habitat Program provides living, sacred spaces for people to engage directly in the care of God's creation at home and in their communities. By restoring habitats with reverence for our Creator, the program draws people closer to God and his Church while protecting the integrity of creation, (SKC 2019).

The St. Kateri Centers operate principally in the United States to develop ecology programs and Catholic Land Trusts, but the work of the organization is one that can be emulated in any environment in the world. The organization's mission statement illustrates the concepts of subsidiarity, solidarity, and the common good applied to environmental conservation and restoration. These principles of Catholic Social Teaching focus on the empowerment of local actors, starting at the family and individual level and working through the societal hierarchy into the parish and greater community levels of action. This calls back to how the individual is seen in the eyes of the Church and in its social teaching, specifically as individuals who find their fullest expression of existence in the community they reside in, first and foremost in the family and in the Church. Solidarity is the value 
that requires human action to build a better community. In Sollicitudo Rei Socialis, John Paul II enumerates the value of solidarity when he reminds his readers that individual persons are part of a universal human family, and that we are all bound with the duty to build a community that empowers each member to attain their full potential. In so doing we aid one another in making the world a better place to live (1987).

Applied to environmental conservation, solidarity is the call of the institutional Church and the broader society for people to act to protect and restore environmental sites close to home. The most effective means of positively supporting the common good is in action close to home. John Paul II continues this thought when stating that solidarity "is not a feeling of vague compassion or shallow distress at the misfortunes of so many people, both near and far. On the contrary, it is a firm and persevering determination to commit oneself to the common good; that is to say to the good of all and of each individual, because we are all really responsible for all"(1987, para.38). In the secular literature, community theorist and former elected official Daniel Kemmis offers a similar perspective when stating that the problems of the contemporary world require a different form of political action to address, one that focuses on place and the impact place has on the lives of everyday people (Kemmis 1990).

The community development literature is instructive here. The concepts of subsidiarity and solidarity are frequently found in that literature under the label "relational placemaking," which is defined by one set of researchers as "the networked, political processes of place-framing," (Pierce 2010, 54). This framing is especially useful in 
addressing habitat restoration and framing such efforts beyond the utilitarian economic arguments for such work but instead of fostering an identity with the land and place that will help ensure future generations will address stewardship issues seriously. This can be expanded even to a global sense of place, which "signifies that place identities range from the local of a neighborhood to national territories to an awareness of an interlinked, global environment. In these treatments, place identity is centrally about the combinations of people and institutions that agree upon or recognize themselves as part of a shared community," (Pierce 2010, 57; Massey 1991; Massey 1994).

Pierce uses the example of land-use reforms in Bolivia to illustrate the example of natural resource access and the building of more robust communities connected to the land. However, as I will show, this example is better understood as a tragic lost opportunity to institute reforms in keeping with integral ecology. To this we can use the example of the work of the St. Kateri Center and its application of stewardship, solidarity, and subsidiarity as an alternative to the implementation seen in the Bolivia case. In 2005, a Marxist political party came to power in Bolivia and instituted land reforms, which were designed to return land to the control of indigenous peoples. "Led by Evo Morales, the party has pursued a pluri-nationalistic platform aimed at redistributing power to historically marginalised indigenous communities, particularly from the western altiplano and central chapare and highland regions of the country....Natural resources have been at the centre of these struggles as the state has nationalised petroleum and mineral reserves," (Pierce 2011, pg. 62). These reforms were not well received by Morales' opponents, who staged a counterreform movement: 
In response, private-sector elites, primarily from the eastern departments or provinces, have organised for regional autonomy. A core objective of the elite-driven social movement is to enable private enterprises and eastern regions to retain greater control over the profits of natural resource extraction. Forest resources have also been contested as the migration of Andean and highland people, coupled with rapid growth in the wood products industry, have created tensions over forest access and control," (Pierce 2011, 62).

The economic success of Bolivia has been surprising to outside observers, with annual GDP growth rates of about 5\% per annum, poverty halved, and estimates ranging from $55-60 \%$ of the land being controlled by the indigenous population of the country. This initially may be deemed a success for those calling for a wider distribution of land among the people, but the efforts of Morales have not had the desired effect in general. This can be considered another example of where working with the Church for reform efforts would likely have been beneficial. For example, Morales' reforms did not lead to a cessation of deforestation, but instead to an increase of deforestation and development projects that increased environmental degradation (Eichler 2019; Kaufmann 2019). Morales famously took to task the American and European environmental NGOs for pushing Bolivia to curb greenhouse gas emissions when the country is only responsible for $.01 \%$ of the emissions of the world while its forests are responsible for $2 \%$ of natural carbon capture (Smith 2018). This is perhaps a tragic irony given that Morales' policies resulted in continued extractionist policies and environmental degradation. The profits of these efforts were directed towards the benefits of the poor and the indigenous peoples but had been labeled as neo-extractionist by his former supporters, leading to his exile in 2019 , due at least in part to his claiming of arbitrary power to rule (Mounk 2019). 
One lesson is that Morales could have adopted the approach of the St. Kateri Center and Catholic Social Teaching broadly. The ground is fertile for this action, especially after Pope Francis's 2015 visit, where he apologized for the Church's historic role in colonialism and decried the new colonialism of neoliberalism (Yardley 2015). The success of these programs and programs like them require a robust sense of place, and an understanding of the interconnectivity of peoples and places, such that localism can thrive when appropriate and, when needed, larger scale initiatives to combat wicked problems can be implemented without resulting in too much social strain. This is the nature of subsidiarity and solidarity, especially as expounded in Laudato $\mathrm{Si}$.

These essential values of Catholic social teaching, and especially of integral ecology, are embodied in the work of the St. Kateri Tekakwitha Habitat Program. This organization states the following as the motivation behind the organizational mission: "The Saint Kateri Conservation Center offers a faith-based program to inspire Catholics and others to restore yards, gardens, schools, farms, parks, forests, rivers, and wetlands into healthy habitats for people and wildlife. We do this close to home, where we live. The Saint Kateri Habitat Program encourages individuals, parishes, schools, religious orders, and working landowners to restore their natural homes in a way that praises God and fosters a greater connection between people and nature. With a special focus on Catholic faith and social teaching, the Saint Kateri Habitat Program provides living, sacred spaces for people to engage directly in the care of God's creation at home and in their communities. By restoring habitats with reverence for our Creator, the program draws people closer to God and his Church while protecting the integrity of creation,” (2019 St. Kateri Center). 
The emphasis on working close to home is both the most hopeful and challenging aspect of Catholic Social Teaching and the work of the St. Kateri Center and programs like it. Modern cultures around the world are increasingly developing a relationship between humans and nature that is separate as envisioned in the Liberal schools of thought, where nature is looked purely as a source of resource extraction for generating wealth through labor (see Locke 1689 [2017], 181).This purely materialistic understanding of the world has been adopted by many Christian denominations, and it is a view that the Church has stood against even if not explicitly in the case of environmental conservation and stewardship. The St. Kateri Center and organizations like it seek to transcend this materialistic view of the world that is causing great harm to the ecosystem by emphasizing both subsidiarity and solidarity as well as the religious nature of the work that is meant to honor the Creator.

\section{Implementation}

At the start of this dissertation I stated that the purpose of this examination of Catholic Social Teaching in the framing of sustainable development and social justice was in the context of the developing world. The purpose is to see how these principles could be implemented in the developing countries with a large Catholic population and the cultural conservatism that frequently is associated with these countries. This dissertation now turns to implementation of Catholic Social Teaching principals in keeping with sustainable development benchmarks. This approach provides a unique opportunity that transcends 
monied interests, collectivist influence, or other approaches that result in purely materialist development efforts that fail to avoid becoming another neo-extractivist policy failure.

As stated previously, central values of Catholic Social Teaching, subsidiarity, solidarity, and stewardship with the goals of supporting the common good are the key components of Catholic Social Teaching from which all other areas of analysis and proposals are drawn from. Taken together they project an image of the desired society that is sustainable due to its decentralized empowerment of local people working together as members of a tightly-knit community living in harmony with their neighbors, the Church, and with the land to strengthen the institution of the family as the basic building block of society. The lessons for policymakers and development specialists should be apparent. The example of Bolivia provides a clear path for policymakers who seek to both continue to protect economic growth while placing land back into the hands of those with the greatest interest in preserving natural resources. This, in spirit, is in keeping with the Distributists' goals of widespread ownership of private property, though the Distributists framed this in ownership by individuals, families, and (for workplaces), cooperatives (Belloc 1912; Chesterton 1926).

At present, much of the Catholic Land Movement and the efforts of those inspired by Laudato Si and the works of Popes Benedict XVI and John Paul II prior, are focused on ecological preservation, which is incredibly important for addressing the climate and ecological crises of the present. But certainly not all land trust work has a purely ecological purpose. The case of the Land Trust project in Iowa City is one such example. This project 
combined the preservation of a historic 2,800 square foot home with the goal of not only preserving a historic place but also turning the historic home into a shelter for the needy, which combines the often under-emphasized aspect of Catholic Social Teaching: the corporal and spiritual works of mercy or, in everyday language, acting in charity. This project was launched successfully by the local chapter of the Catholic Worker, which traditionally focuses on the issues of charitable works and the economic aspects of social justice, such as poverty and, historically, the plight of the worker in the industrialized world (Zwick 2005).

The Iowa City case not only involved the preservation of a historic mansion and the renovation of the property into a shelter for the homeless, it also involved the institutionalization of the property and its renewed purpose with legal protections. The property was placed under the legal trust of the archdiocese but is managed by the local chapter of the Catholic Worker. "Formally establishing Catholic Worker House through a trust was one of three primary goals of the organization when it started in 2016. The other goals were offering transitional overnight housing in a community environment and establishing a weekend meal program. All three goals have now been met," (Steele 2018). This action represents the application of subsidiarity, solidarity, and stewardship for the common good applied in the realm of practice, with stewardship especially taking on a role beyond the protection of material and natural resources to now include stewardship or care for the most vulnerable members of society. "The purpose of this trust is to further the aims and goals of the Catholic Worker Movement as expressed by Dorothy Day and Peter Maurin...To that end the Trustees shall use the Trust Estate to provide hospitality and 
refuge to the poor and oppressed and to provide a location for a Catholic Worker community." This then places the operative of the non-profit organization in near constant proximity of those they are serving.

What are the lessons here for non-religious organizations? That, whenever possible, locals should have control or at least a great deal of input into actions taken that affect them. This can be accomplished by undertaking works that emphasize the relationship of those who live in affected areas to the land, community, and peoples they live with. Local actors should work closely with relevant authorities, as is the case of the Iowa City Catholic Worker, who worked closely with the archdiocese and with local credit unions and lawyers to accomplish the goals of program implementation that can be broadly described as socially sustainable in nature (Steele 2018). Working with these groups can be of major benefit to the activists, as the security gained from working with long established organizations should make clear. But there is another benefit, and it is illustrated by what happens when an organization does not work with local actors and local authorities when it is appropriate to do so. While not unique to CST, the central value of subsidiarity does call for respecting and working with local authority as much as possible (Golembowski 2015).

The case is that of Kenya and the vaccination programs of 2014, led by the Gates Foundation and the World Health Organization. This case and its slipshod implementation and execution caused such controversy that it has become the stuff of internet conspiracy theories that have re-emerged in light of the COVID-19 pandemic and the role Bill Gates 
is playing as a global leader in the response. The facts of the case are straightforward: The Gates Foundation, with the permission of governments of various countries including Kenya and Nicaragua, among others, distributed vaccines against Tetanus to the populations of these countries. These vaccines were contaminated with a chemical that caused sterilization, resulting in the sterilization of at least half a million people in various countries of the developing world (Warren, Abuya, Obare, Sunday, Njue, Askew, and Bellows 2011). This case has unfortunately not been given the serious scrutiny by serious academic researchers that it deserves, partially due to the sensitive nature of the subject coinciding with critical action being taken by the Gates Foundation to develop a vaccine that much of the world's population will likely receive in the coming years. But it is worth exploring in brief here.

The Kenyan bishops raised the alarm about these vaccines. The Catholic Church in Kenya is responsible for operating approximately $80 \%$ of the hospitals and health care facilities in the country, and as such would be a natural partner for the implementation of a major vaccination program. The Church directly employees the health professionals and owns the facilities necessary to make the implementation of this program significantly easier (KCCB 2014). The bishops released a statement about this program that raised serious concerns against the program of the Gates Foundation and the Kenyan government:

Before the March and October 2014 mass tetanus vaccination campaign, the Catholic Church raised concerns about the safety of the vaccine that was being used. This was informed by what had happened in Mexico, Nicaragua and Philippines where WHO/UNICEF had conducted similar campaigns using tetanus toxoid impregnated with beta HCG that causes production of antibodies against the natural HCG resulting in 
permanent infertility. The mass tetanus immunization campaigns in Kenya in March and October 2014 were also sponsored by WHO and UNICEF. The Catholic Church requested the Ministry of Health that the vaccines be tested before use to ensure they were safe. These requests were rejected by the Ministry of Health. Subsequently, the Catholic Church independently sampled nine vaccine vials from the two campaigns with difficulty. Six of these vials were tested in five different laboratories here in Kenya. One third of the vials (3/9) were found to be laced with beta HCG, (Njue 2015).

The document continues and lists methodological questions regarding laboratory results, transparency of the Kenyan government and NGO partners, and the lack of communication with Church officials in the implementation of this program. This claim that HGC was found in tetanus vaccines in Kenya has been verified by independent research (Oller 2020). The Bishops Conference released a press statement that coincided with the statement above leveling serious charges against the WHO, UNICEF and, by extension, the Gates Foundation and similar non-profit organizations that have as yet to be answered in a way that will satisfy the Bishops conference and the vaccine skeptics, let alone the promoters of conspiracy theories:

"Information in the public domain indicates that Tetanus Toxoid vaccine (TT) laced with Beta human chorionic gonadotropin (b-HCG) subunit has been used in Philippines, Nicaragua and Mexico to vaccinate women against future pregnancy. Beta HCG sub-unit is a hormone necessary for pregnancy. When injected as a vaccine to a non-pregnant woman, this Beta HCG sub-unit combined with tetanus toxoid develops anti bodies against tetanus and HCG so that if a woman's egg becomes fertilized, her own natural HCG will be destroyed rendering her permanently infertile. In this situation tetanus vaccination has been used as a birth control method. The ongoing tetanus vaccination campaign bears the hallmarks of the programmes that were carried out in Philippines, Mexico and Nicaragua. We are not certain that the vaccines being administered in Kenya are free of this hormone. The Catholic Church acknowledges that maternal and neonatal care is imperative in prevention of death; the Church therefore 
maintains that adequate and clear information is provided to the general public to avoid misinformation and propaganda in regard to the vaccine. The sanctity of Life and the dignity of the human person must always be priorities in health care and the Catholic Church, in the absence of proper and adequate information will not shy away; from raising moral questions on matters affecting human life," (KCCB 2014).

There is an obvious lesson to be learned from this case: the WHO, UNICEF, and the NGOs operating in Kenya and other countries should take care to promote vaccines free of these contaminants. But further, and less obviously, these organizations should work with the local bishops' conferences of any country where these vaccines are going to be administered if the Bishops control the majority of health infrastructure in a given country. Additionally, local authorities should be worked with whenever possible, at the very least to help alleviate concerns with transparency when modern medicine and the technical aspects of administering medicine are not fully understood by the population of countries. This has the additional benefit of helping ensure that there is no perception that the people are being targeted for a new form of colonialism, as has been alleged by some in that country(KCCB 2014). This concern is reflective of the human dignity component of subsidiarity, which states that local persons are often the best place for decision-making power in the pursuit of policy objectives. This is especially relevant when real expertise is available among the local community that is affected by the proposed policy. This helps to ensure the rights of the people affected by the policy are protected (Golemboski 2015).

These accusations are almost certainly the result of poor communication, lack of respect for local Church authorities, and possibly the belief that the NGO had the resources to implement this program without the help of local officials. At the most basic level, 
subsidiarity, stewardship, and solidarity require communication, recognition of the dignity of the local actors, and the knowledge and respect of cultural norms in the affected countries that may have been lacking in this case. The failure to respect these norms and the failure to do basic due diligence to ensure that medical products do not contain hazardous contaminants can cause potentially catastrophic social consequences in future emergencies, as can be seen with the spread of conspiracy theories born from this crisis in the pandemic of 2020 (Sherr 2020).

The final case for subsidiarity and the emphasis on place that stems naturally from subsidiarity is the issue of food security, which at the time of the writing of this document has become an issue that many policymakers may have to deal with as a consequence of the COVID-19 outbreak in 2020. At the root cause of this concern is the halting of economic activity. This has led to worries that hunger may rise globally consequently. The integrated food system and supply chain has been exposed to being fragile in the highly technical system of food provision that is highly centralized in nature (UN 2020). A means of addressing this issue has been addressed in the underlying principles of the Catholic Land Movement in the value of placemaking, especially in policymakers adopt an understanding of development and social justice issues that recognizes the complex nature of wicked problems, which requires re-envisioning policy solutions in the eco-economic paradigm (EEP). This understanding rightfully integrates economics and ecological policies to reflect the real-world nature of these issues and envisions them not as separate competing issues but rather as a complex series of policy problems. At present these issues are often envisioned in the paradigm of the globalized economic system (Marsden 2011). 
However, crisis conditions in the 2020 pandemic have shown that under certain conditions governments may resort to breaking from the globalized system (if only temporarily), causing widespread disruption (Good 2020). Marsden's approach from a strictly secular perspective of developing a sense of place in the process of embracing Eco-Modernization offers a way forward that is compatible with CST principles of subsidiarity, solidarity, and stewardship for the common good that calls for the:

“....development of distinctive economic geographies: significant clusters of firms, termed 'Jacobian clusters', where geographical proximity facilitates knowledge 'spillovers' among neighbouring and 'related' industries. These synergistic networks, in turn, foster localised diffusion of innovation....bioclusters of firms are important for regional economic growth....."(Marsden 2011, 218).

This technical response to the consequences of globalization are fully compatible with CST principles and offer NGOs and government policymakers great potential for partnership with local actors. Marsden uses the examples of Latvian placemaking efforts for food production, tourism, and athletics as opportunities to address the loss of a sense of place in a globalized environment (Marsden 2011, 220). The same principles can be applied to avert or minimize the impact of disrupted globalized systems in crisis conditions through the embracing of these principles and working jointly with local actors and government officials to create more robust systems for preventing food scarcity by recognizing the natural intersection of place, subsidiarity, and stewardship.

At the start the purpose was to examine these ideas with the developing world in mind, not the developed or 'first world' as the frame of analysis. The barriers to 
implementing these ideas in the secularized, statist-capitalist developed world are themselves a wicked problem that is unlikely to be addressed short of a disjunctive event that would open what policy theorists refer to as the policy window (Russel 2006) for comprehensive structural reform. The developing world, which is still trying to free itself from the shackles of western colonialism, is much more fertile ground for institution building than the developed world is now. However, there are barriers to implementation even in these countries. A brief look at those barriers will be examined. They'll be familiar to many policy theorists.

\section{Barriers}

The barriers to implementation of the principles of Catholic Social Teaching to the development question and the sustainability question more broadly in the developing world are numerous. The administrative literature clearly illustrates the corrupting nature of grant money flowing from governments to non-governmental entities. One such example of corruption os the dependency on NGOs to governments for funding, which influences the mission of NGOs to reflect the policy goals of governments. Grant funds are awarded with a specific purpose that often conflicts with the self-image of non-profit organizations or can functionally alter the long-term mission of the organization in practice (Dolnicar 2008). It should almost go without saying that often the proposed aims of federal grant programs in the developing world run into conflict with the stated values of Catholicism and the Catholic Church, including areas of population control and spread of economic values often 
termed neoliberal (Lepanto 2015; Ferrara 2010).

In this, Pope Francis and the institutions of the Catholic Church (both formal and informal) are natural allies to $\mathrm{NGO}$ and inter-governmental efforts to reject new forms of colonialism and to strengthen efforts at promoting sustainable development and social justice in the developing world. Francis has taken a strong stance against anything resembling imperialism and colonialism in the developing world, especially involving Europe and the United States, who are the biggest funding governments for development efforts around the world today (OECD 2019). One such example is when Pope Francis addressed The World Meeting of Popular Movements in Bolivia in 2015 when he stated "The people of the world want to control their own destiny and want to march peacefully towards justice... They do not want to be lectured and they don't want interference from the stronger who subordinate the weaker...," (Francis 2015, para. 33). This is only one example of many from the pontiff, and his famous words regarding the migration crisis facing Europe have drawn a wide variety of reactions from Catholics and from the secular world from across the political spectrum. The present pontiff has demonstrated a form of leadership that makes him and by extension the institutional Church hostile to ill-intended or poorly thought out efforts to develop the developing world, and as such, he and the Church presents themselves as natural allies in the efforts to provide a more effective means of bringing these efforts to fruition in the developing world through the application of the principles of CST that are compatible in many ways to existing efforts, and in others reinforcing of core principles of sustainability while challenging internal inconsistencies often contained therein. 


\section{Moving Forward}

Future research in this area is certainly called for. One of the major issues warranting greater research is the evolution of the focus of Catholic Social Teaching beginning in the mid-20th century, coinciding with the Second Vatican Council and how to reconcile these changes within CST in order to rectify any internal tensions, such as the tensions with subsidiarity and authority in an increasingly globalizing world. Catholic Social Teaching is historically presented by popes such as Leo XIII and Pius XI in terms that are not overly precise in order to avoid limiting its scope to a specific place in time. In different times and circumstances the implementation of CST principles in real scenarios may differ dramatically based on issues at hand, but the internal values remain remarkably consistent, rooted in the recognition of the inherent dignity of man that requires subsidiarity, solidarity, stewardship of resources, and an integral ecology, all aimed at promotion of the common good. This evolution of application should be studied in the context of Benedict XVI's hermeneutic of continuity (Hahn 2007; Benedict XVI 2005). This evolution of application can be understood in a greater focus on political specifics and especially technocratic solutions to social problems, embodied in the granting of the state and non-profit organizations greater power to address perceived sociopolitical ills when appropriate due to modern complexity. The contemporary view acknowledges the role of supranational organizations in addressing issues of governance, especially as they relate to peace and the environment. An example of this are the words of Pope Francis in 2019, when he stated in an address to the Pontifical Academy for the Social Sciences, "When a supranational common good is clearly identified, there is need for a special legally 
constituted authority capable of facilitating its implementation....Think of the great contemporary challenges of climate change, new slavery and peace," (Francis 2019). This statement, certainly not unique to Francis. His predecessors' (beginning with Paul VI) increasingly embraced supranational organizations in a recognition for the potential need in some cases of greater technocratic solutions to contemporary problems that are overly complex in nature. At this point in history this approach may be an appropriate response for the Church, whereas the future social conditions may require a different response. It is best to understand Catholic Social Teaching as being flexible in addressing policy issues in an environment of changing complexity. Catholic Social Teaching presents principles that are balanced in offering guidance for solutions. Often to achieve a policy solution requires an understanding of subsidiarity even when the problem under scrutiny does not rely on local actors to solve. It still does call for respect of local peoples, cultures, and should as much as possible incorporate their input in seeking a solution. This can be understood as a tradeoff between subsidiarity, solidarity, and stewardship, or it can be understood that CST is not a repackaged form of federalism (with duties and powers for each level of government outlined) but rather an approach to governance that at times requires governments to not be involved in some problem solving activities and at others requires not only governments but potentially multiple governments working in partnership to address wicked problems. This is what sets CST apart from traditional political ideologies, as a one size fits all approach to policy design and implementation is often the result of ideological thinking. For future research, the question can be understood as: what is the role of the Church in the modern world in light of seemingly conflicting attitudes of 
the pre-conciliar and post conciliar popes?

Since the Second Vatican Council, divisions have become apparent over the interpretation of Catholic Social Teaching and its proper implementation. These divisions often reflect the application of secular ideologies as an analytic framework for interpreting the veracity of the CST principles or the extent to which they may be applied. Or, as is often the case, by rejecting the claims made by popes against certain secular ideologies, thus leading to the notion that the Church has little of substance to say on issues of economics, politics, or the ecological crisis. A remedy for this is needed but the way forward is murky. For a researcher, this is a much more difficult task than it may appear, as much of the literature on the Council is clearly tainted by the various ideological viewpoints that have unfortunately characterized life in the Church since the Council. While Christ asked on the Cross that his followers all be united (John 17:21), the reality within even academic circles in the Church is a factionalization that is similar to what is easily seen in the broader society. From the perspective of a researcher this is unfortunate, as it makes diagnosing the proper policy response that is in keeping with CST difficult. Given the Church's embracing of academic and intellectual freedom, what is the role of the Church in correcting this factionalization? How can this coopting of CST be overcome in the public sphere in a manner that does not corrupt attempts to solve critical policy issues?

For practitioners, the prescription that should be adhered to is to first adhere to the original source material or works that faithfully summarize them and adhere to the understanding of CST that I outlined herein, which places the critical balance of the 
following four values as the primary guiding principles for implementation: subsidiarity, solidarity, stewardship, and the common good. As has been stated numerous times, subsidiarity is the principle that social and political issues should be addressed by the most local competent authority, including when possible neighbors working together for their mutual good or families working internally to address issues. This principle is similar to those seen in the secular sustainable development literature from authors like Cooper and Vargas (2004) where the principle is that local peoples in developing and post-conflict areas should do the work necessary for development. This principle does not exclude the role of outside international expertise in development efforts. More contemporary Catholic Social Teaching does advocate for greater roles of supranational and multinational organizations in addressing governance problems. This can be reconciled with subsidiarity when it is understood that the dignity of the person that the Church has championed for centuries requires a recognition of what Cooper and other secular theorists have stated, that local peoples should be respected in diagnosing development problems and should be relied upon to do the bulk of the development work, with appropriate assistance from outside groups that do not usurp the authority of the affected peoples in their own lives and communities (Cooper and Vargas 2004; Cooper and Vargas 2008).

The influence of foreign experts in developing states can exceed merely simple development issues, such as bridge building, well digging, agriculture, or other areas that are of little controversy. This influence can include issues of statecraft. A consistent criticism of development efforts is the lack of a codified system of property rights that has enabled foreign commercial enterprises to exploit peoples of developing nations, 
purposefully or otherwise (Michon and Michano 2020). Catholic Social Teaching declares private property to be almost sacred, though not without limitations (Leo XIII 1884). An essential element of sustainable development is the sense of ownership that comes as a consequence of ownership of the land. This does not have to be a contemporary western understanding of property ownership but can be fitted to the cultural needs of the people in developing countries. The essential point is that a codified system of property rights can enable protection of the people from outside predation, as well as meeting the basic Distributist observation that property ownership is essential to the freedom of the people (Chesterton 2013; Belloc 1936). The case of Bolivian land reforms can fit this prescription, though questions of justice for the previous landowners remain, as the Church's solution does not endorse forcible land seizures and redistribution measures backed by threats of violence. But the underlying result is compatible with CST principles of private property, where in the case of Bolivia they have been applied to a communitarian sense of property ownership. This application may be appropriate in other parts of the world as well and should be examined with an understanding of the cultural context of the affected peoples in each place and their relationship to place.

The lack of land reform is a major barrier to development efforts in the developing world. Land reform encompasses all three areas of sustainable development and social justice. Land reforms are laws that are designed to and are often successful at reducing poverty by increasing the share of the land owned by the poor, as well as the enshrining of property rights in the law. These reforms often face barriers of implementation that run the gamut of questions regarding the need to collectivize ownership, the need to eliminate 
collectivist ownership in favor of individual or family property rights, issues of rent and tenancy, and land division (Lipton 2009). Property rights failures are considered one of the major driving factors of environmental destruction (Heltberg 2002; Pearce and Turner 1990). This issue is, according to one World Bank study, one that can be alleviated by strong governance reforms assisted by non-governmental organization influence (Feder and Feeny 1991). My research has found no Catholic organizations of note engaging in the hard work of institutional governance reform on the issue of property and land reform in the developing world. This issue is critical because ownership of private property is central to the maintenance of a properly ordered free society that ensures familial stability and social cohesion (Leo XIII 1891; Pius XI 1931; Chesterton 2013; Belloc 1936). As stated above, a way forward for achieving this issue of governance is the codification of communal land and property rights, one that recognizes the rights of indigenous groups as well as the individual members of each group. Respect for the cultural traditions and arrangements of these groups is essential, especially when considering the dignity of the person. This is an area that should of special interest to the Distributists, who emphasize property rights and membership in guilds and trade unions as a means of achieving economic justice (Ederer 2011; Pearce 2001; Schumacher 1973). Relevant questions for the Distributists are: what does private property ownership mean in cultures that have communal social structures? What would a legal framework look like that protects their property rights? How is property placed into the hands of indigenous communities that are presently owned by foreign corporate entities and by national governments without violating the rights of the present property owners? These are the kinds of questions that 
the Distributists have thus far not engaged with, and to bring one expression of CST into the contemporary era of policymaking and solutions finding requires an engagement with modern issues that some of these theorists might find uncomfortable.

It must be recognized that the issue of property rights is today much more complex than what Chesterton and Belloc confronted in the early $20^{\text {th }}$ century. There has been a great debate about the nature of property ownership and efficiency. While the Distributists have not been concerned with economic efficiency, they are principally concerned with rights and the protections property ownership afford. How this translates into the indigenous experience is an issue that needs to be explored. The work of Ostrom on indigenous land rights may light the way for Distributists in the coming years. This is an issue of communal property rights, which exist when a group of people has established a means of governing themselves. This is the essence of Common Pool Resources (CPRs). Communal property ownership solves many of the issues of economic power that the Distributists are concerned with, which Ostrom characterizes as the right of alienation (Ostrom and Hess 2000). This is the right to determine who can and cannot use the property, classically called the right of exclusion (Olson 1965). This right of exclusion or alienation strengthens the regime of communal ownership, which has been shown to be a more efficient use of land resources than previously assumed (Olson 2003). This, in turn, may be more in keeping with the integral ecology of CST, as the latest developments in the social teaching of the Church emphasize a greater integration and connectivity of persons and the land. This interdependence on nature for humans requires escaping much of the individualist tendencies of modern thought, which the Distributists attempted to overcome 
with an emphasis on the family (Belloc 1924). One means of bringing this school of thought into the contemporary discussion of CST is a re-emphasis on the family as embedded in human society, and that society requiring recognition of certain duties to both humans and the natural world without overt preference to humanity as part of the Godgiven duties to the natural world. This is an essential debate to be had within CST circles, as the state of economic development in the world calls for a robust Catholic response.

One example can prove illustrative to this point: South American nations consistently rank at the bottom of most international economic lists in regards of private property protections, and consistently run in near parity with African nations in most measures of poverty. The International Monetary Fund (IMF) ranks Venezuela last in South America for protection of property rights, and Argentina is not far behind. Both states have a history of expropriation of property and a failure to institutionalize private property norms common in the developed world among indigenous peoples and the extremely poor. As stated already numerous times, private property rights are central to Catholic Social Teaching, as ownership of property protects family rights, promotes the freedom of families and individuals (Chesterton 2013; Belloc 1936), as well as provides a basis for a stable polity (Locke 2014).

Does the underlying principle of subsidiarity override private property rights? Or can private property be understood in the communal setting? This would require an understanding of the concept of 'private' to be extended to the tribal or communal level, and subsidiarity as a concept may show the way. The built-in assumption of subsidiarity is 
that often times national governments (or international governing bodies) are not the appropriate place for decision-making authority to reside because the result of distant policymaking is the "one size fits all" approach is often how distant decisionmakers impose policy solutions. Perhaps the Distributists and others should understand that a static definition of private property rights that places the concept of private as a concept applied strictly to individuals is also a "one size fits all" solution that should be mitigated by cultural norms. Distributism already has this understanding of property built-in to the idea system as is, with the concept of cooperative ownership of shops, factories, and other medium-scale productive industrial operations. Aleman illustrates this concept in his online article for the Distributist Review:

"Worker-ownership, or "cooperatives" as they are commonly called, alleviates the tensions wrought by the separation of ownership and work because it eliminate this division, and it increase ownership because cooperatives are multi-partnerships, organizations owned and operated by a group, utilizing diversified tentacles of capital investment and resources. The employees are the capital owners. Instead of one person raising capital to incorporate and invest in overhead, the cooperative is a shared investment by several people. Cooperatives benefit from their collective bargaining power, pooling operational costs, and stretching limited resources." (Aleman 2011).

Can indigenous groups be understood in the same way as employees are? Can they be understood as capital owners who "benefit from their collective bargaining power, pooling operational costs, and stretching limited resources" in their relationships with outside groups, including corporations and governments? This is fertile ground for Distributists to bring the claims they make and solutions they offer into the contemporary 
realm of sustainable development in the international realm of policymaking.

Additionally, it could be said that property rights promote responsible and sustainable development. As stated by the PERC institute, "sustainable development, if it can be defined, is only possible in a legal system where property rights are well-defined, enforced, and transferable," (Hughes and Anderson 2003). That summarizes in a short sentence the prevailing issue in much of the developing world, where it can be argued that the colonial powers that had run these now affected states and regions made little effort to establish law-based property systems or failed to do so before the relatively sudden demise of the formal colonial system, leaving many states in the developing world without functional systems that recognize private property rights and transferability of property that is compatible with the ancient traditions and customs of the peoples affected. This latter concern can be understood as the concern of subsidiarity, which beyond its policy making aspect can be understood as respect for persons and peoples by those more powerful.

An example of this from the developing world is encouraging. Traditional notions of property rights that come from the developed world typically envision individual ownership or ownership in the hands of a private capitalist enterprise. Another viable model is seen in Nicaragua, which the World Bank says may serve as a model for clarifying property rights in the developing world by placing ownership in the hands of families and tribes (World Bank 2017). According to the World Bank:

Through the First and Second Land Administration Projects (PRODEP I and II), their territory was demarcated and the community given a registered title that recognizes the collective property of their territory, 
including not only their settlements but their forest lands and sacred places. This allowed the community to gain direct control over natural resources and a better bargaining position with outsiders who may want to invest there. Long-standing inter-territorial conflicts, including between different Indigenous Peoples, were resolved through a participatory process of demarcation and alternative conflict resolution mechanisms, (World Bank 2017, para.10).

Conflicts in land rights remain, including in Nicaragua. It is recognized by the international community that land rights for non-indigenous farmers, ranchers, and companies are important as well. A strengthening of the legal regime that recognizes the rights of all parties is needed, one that does not necessarily place primacy on individualistic or capitalist land operations while not infringing on the rights on non-indigenous owners. The foundation for land law reforms has been framed in the indigenous cultural context, which has caused the land rights issue to suffer from intrinsic limitations that have hampered the extension of these reforms to non-indigenous landowners. A greater emphasis on the economic dimension of land may provide suitable protection against future land acquisition schemes that exploit this conflict in the developing world (Diergarten 2019).

The role of the specialist and of the non-governmental organizations that are likely to do the vast majority of development work in this area must respect the principle of subsidiarity and human dignity and can best do so by working with the local population to provide for the development needs of the people as the people themselves understand it. One just action that these organizations can and should insist upon is the development of private property standards and laws that respect local laws and customs while providing 
for a clear legal understanding of property ownership. In turn, legal protection for property rights have been known to strengthen systems of legal responsibilities in caring for and maintaining private and public property, which is essential when protecting the commons.

The role of non-profit organizations is essential for the environmental portion of Catholic Social Teaching. Just as there is at this moment a thriving pro-life movement in the Church that is organized locally and in a loose sense nationally through faith-based groups, so too must there be similar kinds of organizations for the restoration of ecological areas and protection of natural habitats and larger ecosystems. These organizations can teach local persons and groups of people in any culture best practices for working with and building thriving relationships with their natural environment that both enable adequate economic conditions to be sustained for providing for not only the needs of the people but in improving their conditions as well as ensuring that those ecosystems are not negatively impacted so that future generations can continue to live in relationship with the land and with their neighbors. Non-profit organizations seem best suited to this task in the contemporary world, as they can act as surrogates for states in the international system but maintain enough distance to represent the interests of the people they are working with and attempting to protect in an increasingly globalized economic and political environment that is leading to increased concerns about new forms of colonialism appearing on the political landscape (Francis 2015). The Church can take a leadership role if it so chose to assist in the founding of these kinds of non-profit organizations, with assistance from The Institute For Works For Religion (aka, the Vatican Bank), which was founded to assist Catholics in promoting political organizing that promoted and defended the faith against secular threats; 
in today's political landscape, the Vatican Bank is uniquely situated to assist in providing financial assistance to organizations that promote the Gospel and defend the created world simultaneously. 


\section{Conclusion}

Catholic Social Teaching is an under-explored area of discourse in political science, theory, philosophy, and in the administrative literature. The fact that the Catholic religion is experiencing explosive growth in China, Africa, and other parts of Southeast Asia makes having an understanding of Catholic Social Teaching (CST) an imperative for those developing policy and those doing the legwork of sustainable development, institution building, and promoting social justice in those areas, as well as in traditionally Catholic areas such as South and Central America. Those areas are traditionally referred to as parts

of the developing world and as such have been of prime interest for various NGOs and IGOs for promoting sustainable development work in the post-colonial and post-Cold War period.

This concern has become of especial importance in light of numerous papal writings on the environment, most recently Pope Francis's encyclical Laudato Si, which embraces the program of sustainable development and the role of non-governmental organizations in ways that the Catholic Church has not done since the start of the modern era of Catholic Social Teaching in the 1880s with the publication of Pope Leo XIII's groundbreaking encyclical Rerum Novarum. Recently a special Synod was held in Rome that focused on the Pan-Amazon Region, and the final document produced by that Synod of Bishops (Francis 2020) reiterated the need for sustainable development in the region.

What are the implications of what the Catholic Church teaches in its social teaching 
body of work regarding the difficult and controversial topic of social justice and sustainable development? The core principles of subsidiarity, solidarity, stewardship, and The Common Good form the key components of the new, emerging concept of integral ecology. This latter concept and its component ideas can provide the key elements for policy makers, activists, and non-governmental organizations to use to guide important work in the developing world. There are numerous overlapping values traditionally used by secular organizations and Catholic Social Teaching, including the need to reconceptualize the relationship between human beings and nature, as seen in the concept of integral ecology (Francis 2020; Kotz 2014; Benedict XVI 2009; Smythe 2014). Much of the overlap includes reordering our relationship with the natural world, the restructuring of economic relationships to be interconnected between the environment and the local community, including the family, and the need to think several generations into the future when considering development and its consequences (Francis 2015; Benedict XVI 2009; Brundtland 1987). Subsidiarity is a guiding principle that is often seen in the secular literature as well, often envisioned either as localism or some sort of globalized federalism (Eagle 2017; Curtis 2003). While compatible with the principles of federalism or localism, subsidiarity as taught by the Catholic Church is envisioned in a more fluid way that places the emphasis on governance solutions at the most appropriate level, often not concretely defined so as to give the greatest flexibility for addressing any variety of wicked problems appropriately. Catholic Social Teaching is not a concrete ideology, although it has inspired ideological movements that have resulted in real world action.

The differences between Catholic Social Teaching and the secular approaches are 
evident as well. The first is that Catholic Social Teaching is neither truly anthropocentric nor eco-centric in its approach. Rather, it is a sort of embedded quasi-anthropocentrism that can be understood better as deicentric, for the relationship of God and His commandments given to humanity are the driving force for the believer in adhering to the values of Catholic Social Teaching, which are the values of the Gospel applied to social problems (Leo XIII 1891; Esolen 2012). Consequently, one difference between secular and Catholic notions of sustainability is the rejection of the environment being sacred for its own sake. This view is widespread among the anti-anthropocentric advocates, who either reject the relational approach to crisis management or have adopted what can only be understood as a hostility to human development, which in turn undermines the efforts to address these problems (Chan 2016).

Catholic Social Teaching is centrally concerned with relationships, but this is not unique to CST. The community development literature and environmental management literature both speak to this concern, and CST offers a bridge for needed dialogue. Chan describes the benefits of a relational approach from a purely secular perspective:

Conservation is still often thought of as something imposed on local peoples by outsiders; it must instead be seen as something we all negotiate collectively as good stewardship. Such programs can be redesigned to foster existing relationships among landowners and with the land, engaging landowners and communities to undertake stewardship actions of their design through cost-sharing and collective action (e.g., via a grant- or reverse-auction model). Such cost sharing for community-based or locally designed conservation should mitigate widespread concerns about fairness associated with the prevailing market-based approach to payments for ecosystem services, and enable more effective and creative conservation," $(2016,1464)$. 
Subsidiarity is a concept that protects the dignity of the human person in making decisions that protect Catholic notions of freedom, which the Church defines as the ability to do what a person ought to do (Compendium 2004, Sheen 1940) but placing authority for decision making in the most local competent office possible. In some cases, subsidiarity requires that national governments or even international bodies address (Francis 2015) what can be described as "wicked problems," that is, problems of such a complex nature that local governments are not equipped to properly deal with them. However, subsidiarity does not require that governments address all problems, as some are properly the sphere of individuals and communities coming together to address these issues themselves.

Solidarity is the principle of CST stating that people should work together for the common good. As John Paul II states in Solicitadu re Socialis, "We are all one family in the world. Building a community that empowers everyone to attain their full potential through each of us respecting each other's dignity, rights and responsibilities makes the world a better place to live," (John Paul II 1987). The implications of this should be clear in the light of subsidiarity: sometimes it is appropriate for governments and other centers of centralized power to let local people address problems for themselves before getting involved in their lives.

Stewardship is the key principle of CST intergenerational guardianship of resources, specifically for financial and environmental issues. Benedict XVI in Caritatis en Veritati provides a working definition in the context of the created environment. "The environment is God's gift to everyone, and in our use of it we have a responsibility towards 
the poor, towards future generations and towards humanity as a whole...In nature, the believer recognizes the wonderful result of God's creative activity, which we may use responsibly to satisfy our legitimate needs, material or otherwise, while respecting the intrinsic balance of creation. If this vision is lost, we end up either considering nature an untouchable taboo or, on the contrary, abusing it. Neither attitude is consonant with the Christian vision of nature as the fruit of God's creation. Nature expresses a design of love and truth,' (Benedict XVI 2009). Stewardship requires that resources be understood in the responsibility individual persons and organizations have to future generations. This is a natural companion value to solidarity.

The common good is a term with fairly obscure origins. Bishop John Wright of Worcester defined this concept in a 1951 sermon in the following way:

The time-tested philosophy of Christendom, blending the hope of Hebrew prophecy, the wisdom of Greek speculation, the sanity of Roman Law, and the charity of Christian Revelation, had a phrase which provides the saving word. That philosophy spoke of a third good, a good wider than that of the individual and warmer than that of the collectivity, a good with richly personal elements, yet truly public in its nature. That third good, conciliating and unifying, is more humane than the mere good of the State; it is more generous than the good of the mere individual. It is, to repeat, both personal and public, though not merely individual on the one hand nor merely political on the other, (Wright 1951, 83) (emphasis added).

Thus, the common good is the subordination of the individual to the social but simultaneously and paradoxically the subordination of the social to the individual. It is the understanding that both the individual and the social must work in harmony. There is a natural tension here, but the concepts of Christian virtue are the governing set of values, 
where the virtuous person will voluntarily make personal sacrifices for the good of others. It can be argued that one purpose of Catholic Social Teaching is to educate the laity on the requirements of Christian virtue in various areas of social concern.

Understood properly, then, the concept of integral ecology is one that sees the virtuous person making decisions in recognition that their actions influence human persons today and into the future, as well as on the natural environment. The values govern this decision-making process, whether it is as an individual actor or as part of a state or nongovernmental organization. The demands themselves of these values do not change except in the natural consequences of individuals attempting to work as an organization. As such, the right-ordered approach to sustainable development for the NGO or state, according to the Church, is to respect local autonomy as much as possible, to emphasize solidarity, and to encourage stewardship. However, subsidiarity does not exist above these other values. Subsidiarity works in concert with them equally, with all of these values working towards defending and promoting human dignity, with each taking primacy as needed. Subsidiarity is similarly observed and called for by the secular sustainable development literature (Cooper and Vargas 2004; Cooper and Vargas 2008).

In closing, as stated at the start of this dissertation, it is worth noting that various Catholic theorists over the decades have made similar calls for decentralized planning and decision-making, a call that has been reiterated by numerous secular figures as well. This has developed in recent decades to a better understanding that the paradigm of globalism and the complex nature of problems that transcend national borders often requires solutions 
that local and national authorities are ill-equipped to deal with themselves. Consequently, at times, subsidiarity and stewardship demand higher-level problem solving that can only be adequately addressed by supra-national organizations or international NGOs. The consequent complexities of this have been explored in depth in this dissertation, including the tendency of technocratic organizations to make decisions with little regard to those affected, which is hardly a new observation in the various policy theorizing traditions. But, perhaps, with the application of Catholic Social Teaching and its principles and proposed ways forward in various areas of concern, this tendency can be overcome by both Catholic and secular organizations and actors. The purpose of this dissertation has been to demonstrate the possibility of addressing such problems with these values in mind. 


\section{References}

Abela, Andrew. 2009. "Subsidiarity and the Just Wage: Implications of Catholic Social Teaching for the Minimum-Wage Debate." Journal of Markets \& Morality, 12(1).

Acton Institute. 2018. "Why Catholic Social Teaching Falls on Deaf Ears." Acton Institute Online. Cited: https://www.acton.org/pub/commentary/2018/01/10/whycatholic-social-teaching-falls-deaf-ears

Ahlquist, Dale. 2003. GK Chesterton: The Apostle of Common Sense. Ignatius Press. San Francisco, CA.

Ahlquist, Dale. 2020. "Lecture 33: the Superstition of Divorce." Chesterton University Online. https://www.chesterton.org/lecture-33/

Aleman, Richard. 2011. "Industry: a Distributist Solution (Part II)." The Distributist Review. Cited: https://distributistreview.com/archive/industry-a-distributist-solutionpart-ii

Álvarez-González, Luis. I., García-Rodríguez, Nuria., Rey-García, Marta., \& SanzoPerez, Maria. J. (2017). "Business-Nonprofit Partnerships as a Driver of Internal Marketing in Nonprofit Organizations: Consequences for Nonprofit Performance and Moderators." BRQ Business Research Quarterly, 20(2), 112-123. 
Anderson, Barry. 1970. "The Bureaucracy-Alienation Relationship in Secondary Schools."

Retrieved from ERIC: https://files.eric.ed.gov/fulltext/ED053445.pdf

Anderson, Terry, Huggins, Laura. 2003. "The Property Rights Path to Sustainable Development." Free to Choose, 57.

Annett, Anthony. 2015. "The Enduring George Weigel Problem.” Commonweal Magazine. Cited: https://www.commonwealmagazine.org/enduring-george-weigelproblem

Aquinas, Thomas. 1911. The Summa Theologica Of St. Thomas Aquinas, Literally translated by the fathers of the English Dominican province. Burns, Oates, and Washbourne Ltd. London, UK.

Aquinas, Thomas. 1949. “De Regno.” Aquinas: Political Writings. Pontifical Institute of Mediaeval Studies. Vatican City.

Argandoña, Antonio. 2013. The Common Good. Handbook on the Economics of Reciprocity and Social Enterprise. Edward Elgar Publishing. Cheltenham, UK.

Arima, Akito. (2009). "A Plea for More Education for Sustainable Development." Sustainability Science, 4(1), 3. 
Asadi, Ali, Akbari, Morteza, Fami, Hosani, Iravani, Hoshang, Rostami, Farahnaz., \& Sadati, Abolhasan. 2008. "Poverty Alleviation and Sustainable Development: The Role Of Social Capital.” Journal of Social Sciences, 4(3), 202-215.

Bakari, Mohamed. 2017. "Mapping the 'Anthropocentric-Ecocentric' Dualism in the History of American Presidency: The Good, The Bad, and the Ambivalent." Consilience, (17), 1-32.

Balint, Peter, Stewart, Ronald Desai, A., \& Walters, L. 2011. Wicked Environmental Problems: Managing Uncertainty and Conflict. Island Press. Washington DC.

Banerjee, Subhabrata. 2003. "Who Sustains Whose Development? Sustainable Development and the Reinvention of Nature." Organization Studies, 24(1), 143-180.

Barro, Robert, McCleary, Rachel. 2003. "Religion and Economic Growth.” National Bureau of Economic Research. Cambridge, MA. Cited: https://www.nber.org/papers/w9682.pdf

Barry, John, and Frankland, Gene. (Eds.). 2002. International Encyclopedia Of Environmental Politics. Taylor \& Francis. London, UK.

Barry, John, \& Smith, Kimberly. 2008. Civic Republicanism and Green Politics. Building a Citizen Society: The Emerging Politics of Republican Democracy, 123-145. 
Bee, Beth. 2011. Gender, Solidarity and the Paradox Of Microfinance: Reflections From Bolivia. Gender, Place and Culture, 18(01), 23-43.

Beer, Samuel. 1986. "The Rule of the Wise and the Holy: Hierarchy in the Thomistic System." Political Theory, 14(3), 391-422.

Behr, Thomas. 2005. "Luigi Taparelli and Social Justice: Rediscovering the Origins of a "Hollowed" Concept." Social Justice in Context, 1(1), 3.

Beisheim, Marianne., and Simon, Nils. 2015. "Meta-Governance of Partnerships for Sustainable Development: Actors' Perspectives on How the UN Could Improve Partnerships' Governance Services in Areas of Limited Statehood." Available at SSRN 2680162. Cited: https://papers.ssrn.com/sol3/papers.cfm?abstract_id=2680162

Belloc, Hilaire. 1936 An Essay on the Restoration of Property. Angelus Press. Saint Mary's, KS.

Belloc, Hilaire. 2004. Economics for Helen. Angelus Press. Saint Mary's, Kansas.

Belloc, Hilaire. 1920. The Catholic Church and the Principle of Private Property. Catholic Truth Society. London.

Benedict XVI. 2005. Deus Caritas Est. Ignatius Press. San Francisco, CA. 
Benedict XVI. 2005. Charity in Truth. Ignatius Press. San Francisco, CA.

Bentham, Jeremy. 1840. The Works of Jeremy Bentham, Now First Collected: Under the Superintendence of His Executor, John Bowring. (Vol. 7). W. Tait. London, UK.

Benzoni, Francisco. 2005. "Thomas Aquinas and Environmental Ethics: A Reconsideration of Providence and Salvation." The Journal of Religion. Vol. 85(3). 446-476.

Berger, Peter, and Luckmann, Thomas. 1966. The Social Construction of Reality: A Treatise in the Sociology of Knowledge. Anchor Books. New York, NY.

Berger, Peter. 1969. The Social Reality of Religion. London. Faber and Faber 1969

Berke, Paul, \& Manta, Mary. 1999. Planning for Sustainable Development: Measuring Progress in Plans. Cambridge, MA: Lincoln Institute of Land Policy.

Bermann, George A. 1994. "Taking Subsidiarity Seriously: Federalism in the European Community and the United States." Columbia Law Review 94 (2): 331-456.

Bernstein, Anna, and Jones, Kelly. 2019. "The Economic Effects of Contraceptive Access: A Review of the Evidence." Institute for Women's Policy Research. https://iwpr. org/publications/economic-contraceptive-access-review. 
Bertone, Tarcisio. 199). "Magisterial Documents and Public Dissent.” L'Osservatora Romano. Weekly Edition January 29.

Bevans, Steven., and Gros, Jeffrey. 2009. Evangelization and religious freedom: Ad gentes, Dignitatis humanae. Paulist Press.

Biden, Joe. 2012. Speech at the 2012 Vice Presidential debate, quoted in Prager, D." Joe Biden's Religion: Catholicism or Leftism." National Review Online. https://www.nationalreview.com/2012/10/joe-bidens-religion-catholicism-or-leftismdennis-prager/

Binkley, Clark. 1998. "Forestry in a Postmodern World or Just What Was John Muir Doing Running a Sawmill in Yosemite Valley?” Policy Sciences, 31(2), 133-144.

Block, Peter, Brueggemann, Walter, and McKnight, John. 2015. Another Kingdom: Departing The Consumer Culture. John Wiley \& Sons. Hoboken, NJ.

Block, Walter. 2007. "Anarchism and Minarchism; No Rapprochement Possible: Reply to Tibor Machan.” Journal of Libertarian Studies, 21(1).

Blythe, John, Lucca, Peter, \& Aquinas, Thomas. 1997. "On the Government of Rulers: De Regimine Principum." University of Pennsylvania Press. Philadelphia, PA. 
Boff, Leonard. 2015. "The Magna Carta of Integral Ecology: Cry of the Earth, Cry of the Poor.” LeonardoBoff. com

Borza, Mioara. 2014. "The connection between efficiency and sustainability-a theoretical approach." Procedia Economics and Finance, 15, 1355-1363.

Brandis, D. 1906. Indian Trees: an account of trees, shrubs, woody climbers, bamboos and palms indigenous or commonly cultivated in the British Indian Empire. Constable. London, UK.

Brennan, Andrew, and Lo, Yuk. 2002. Environmental Ethics. Summer 2002 Edition. Cited: https://seop.illc.uva.nl/entries/ethics-environmental/

Brook, Yarin. 2007. "The Morality of Moneylending: A Short History." The Objective Standard. https://www.theobjectivestandard.com/2007/08/morality-of-moneylending/

Brown, Barrett. 2005. "Theory and Practice of Integral Sustainable Development.” $A Q A L$ Journal of Integral Theory and Practice, 1(2), 2-39.

Brown, Barrett. 2006. "The Four Worlds of Sustainability.” Drawing upon four universal perspectives to support sustainability initiatives. Integral Institute. Boulder, CO.

Brundtland, Gro. Khalid, Mansur, Agnelli, Susanna, Al-Athel, Saleh, and Chidzero, B. 
1987. Our Common Future. Butterworth \& Heinemann. New York.

Burke, Cormac. 2015. The Theology of Marriage. CUA Press. Washington, DC.

Burke, Irene. 2018. "The Impact of Laudato Si on the Paris Climate Agreement." Cited: http://arks.princeton.edu/ark:/88435/dsp013b591c298

Burke, T. P. 2010. “The origins of social justice: Taparelli d'Azeglio.” Modern Age, 52(2), 97-106.

Butzer, Karl. 1983. "Human response to environmental change in the perspective of future, global climate." Quaternary Research, 19(3), 279-292.

Butzer, Karl. 2005. "Environmental History in the Mediterranean World: CrossDisciplinary Investigation of Cause-and-Effect for Degradation and Soil Erosion.” Journal of Archaeological Science, 32 (12), 1773-1800.

Calabresi, Steven and Bickford, Lucy. 2014. "Federalism and Subsidiarity: Perspectives from US Constitutional Law.” Nomos, 55, 123-189.

Callicott, J. B. 1980. “Animal Liberation: A Triangular Affair.” Environmental Ethics, 2(4), 311-338. 
Callicott, J. B. 2013. Thinking like a planet: The land ethic and the earth ethic. Oxford University Press. Oxford, UK.

Callicott, J.B. 1989. In Defense of the Land Ethic: Essays in Environmental Philosophy. State University of NY Press. Albany, NY.

Carruthers, David. 2001. "From Opposition to Orthodoxy: The Remaking of Sustainable Development." Journal of Third World Studies. Vol. 18(2), 93-112.

Catholic Church. 2004. Compendium of the Social Doctrine of the Church (No. 5). USCCB Publishing. Indianapolis, Indiana.

Catholic Relief Services 2020. “Success Stories.” Cited April 6, 2020. https://socy.crs.org/success-stories/

Catone, Staci. 2015. “De Officiis Ministrorum.” Cited: http://xawb.info/gratis/deofficiis-ministrorum-pdf-18668.php

Chan, Kai, and Balvanera, Patricia. 2016. "Opinion: Why protect nature? Rethinking values and the environment." Proceedings of the National Academy of Sciences, 113(6), 1462-1465.

Chesterton, G. K. 1922. Eugenics and Other Evils (Vol. 230). Cassell. London, UK.

Chesterton, G. K. 192). Fancies Versus Fads. Dodd, Mead. New York, NY.

Chesterton, G. K. 1987. The Club of Queer Trades. Courier Corporation. Grants Pass, OR. 
Chesterton, G. K. 2012. Orthodoxy (Vol. 12). Image. New York, NY.

Chesterton, GK. 2013. What's Wrong with the World. Ignatius Press. San Francisco, CA.

Chesterton, G. K. 2014. The Defendant. Simon and Schuster. New York, NY.

Cheung, Esther, Chan, Aalbert, and Kajewski, Stephen. 2012. "Factors Contributing to Successful Public Private Partnership Projects.” Journal of Facilities Management, 10(1), pp. 45-58.

Cho, Yoon-Na, Thyroff, Aanastasia, Rapert, Molly, Park, Seong-Yeon, and Lee, H. J. 2013. "To Be or Not to be Green: Exploring Individualism and Collectivism as Antecedents of Environmental Behavior." Journal of Business Research, 66(8), 10521059.

Collard, Rosemary, Dempsey, Jessica, and Sundberg, Juanita. 2015. "A Manifesto for Abundant Futures." Annals of the Association of American Geographers, 105(2), 322330.

Coloumbe, Charles. 2020. "The Long, Strange Road to a Catholic America." Crisis Magazine. https://www.crisismagazine.com/2020/the-long-strange-road-to-a-catholicamerica

Connelly, Steve. 2007. Mapping Sustainable Development as a Contested Concept. Local Environment, 12(3), 259-278. 
Cooper, Philip, and Vargas, Cynthia. 2004. Implementing sustainable development: From global policy to local action. Rowman \& Littlefield. Lanham, MD.

Cooper, Philip, and Vargas, Cynthia. 2008. Sustainable Development in Crisis Conditions: Challenges of War, Terrorism, and Civil Disorder. Rowman \& Littlefield. Lanham, MD.

Mondragon. 2019. "Corporate Profile: People, the Engine of Mondragon." Cited: https://www.mondragon-corporation.com/en/about-us/economic-and-financialindicators/corporate-profile/

Correspondent. 2015. "Lansing Youth Serve in Guatemala," Ithaca Journal. https:/www.ithacajournal.com/story/news/local/2015/02/25/lansing-town-talk-youth$\underline{\text { mission/23986033/ }}$

Cortner, Hannah, and Moote, Margaret. 1999. The Politics of Ecosystem Management. Island Press. Washington, DC.

Coughlin, John J. 2003. "Pope John Paul II and the Dignity of the Human Being." Harv. $J L \&$ Pub. Pol'y 27, 65.

Crist, Eileen. 2017. "The Affliction of Human Supremacy." The Ecological Citizen, 1, $61-4$ 
CRWC. (2001). "The Columbia River Watershed: Caring for Creation and the Common Good." Cited:

http://www.inee.mu.edu/documents/30columbiariverwatershed 000.pdf

Cummings, Stephen, and Bridgman, Todd. 2014. "The Origin of Management is Sustainability: Recovering an Alternative Foundation for Management." Academy of Management Proceedings ,2014, 1

Curtis, Fred. 2003. "Eco-Localism and Sustainability.” Ecological Economics, 46(1), 83102.

Daly, Herman. 2008. Ecological Economics and Sustainable Development: Selected essays. Edward Elgar. New York, NY.

DeGood, Kevin. 2018.” When Public Private Partnerships Fail: a Look at Southern Indiana's I-69 Project.” Center for American Progress. https://www.americanprogress.org/issues/economy/reports/2018/02/15/446720/public -private-partnerships-fail-look-southern-indianas-69-project/

De Tocqueville, Alexis. 2003. Democracy in America. Regnery Publishing. New York, NY.

Diergarten, Yorck. 2019. "Indigenous or Out of Scope? Human Rights Law Review, 
19(1), 37-52.

Diesendorf, Mark. 2000. Sustainability and sustainable development. Sustainability: The Corporate Challenge of the 21st Century, 2, 19-37.

DiMaggio, Paul, and Powell, Walter. 1983. "The Iron Cage Revisited: Institutional Isomorphism and Collective Rationality in Organizational Fields." American sociological review, 147-160.

Dobson, Andrew. 1999. Fairness and futurity: essays on environmental sustainability and social justice. Philarchive.org.

Dobson, Andrew. 2003. "Social Justice and Environmental Sustainability: Ne'er the Twain Shall Meet.” Just Sustainabilities: Development in an unequal world, 83-95.

Dolnicar, Sara, Irvine, H., and Lazarevski, K. 2008. "Mission or Money? Competitive Challenges Facing Public Sector Nonprofit Organizations in an Institutionalized Environment." International Journal of Nonprofit and Voluntary Sector Marketing, 13(2), 107-117.

Du Pisani, Jacobus. 2006. "Sustainable Development-Historical Roots of the Concept." Environmental Sciences, 3(2), 83-96. 
Durkheim, Emile. 2014. The Division of Labor in Society. Simon and Schuster. New York: NY.

Düwell, Marcus. 2014. "Human Dignity and Future Generations." Cambridge Handbook on Human Dignity, pp. 551 - 558. Cambridge University: Cambridge, UK.

Eagle, Robin, Jones, Aled, and Greig, Allison. 2017. "Localism and the Environment: A Critical Review of UK Government Localism Strategy 2010-2015." Local Economy, $32(1), 55-72$.

Ehrenfeld, John. 2005. "Eco-Efficiency.” Journal of Industrial Ecology, 9(4), 6-8.

Eichler, Jessika. 2015. "Neo-Extractivist Controversies in Bolivia: Indigenous Perspectives on Global Norms." International Journal of Law in Context, 15(1), 88102.

Esolen, Anthony. 2014. “Where Is the virtue?" Public Discourse. Cited: https://www.thepublicdiscourse.com/2014/04/12443/

Esolen, Anthony. 2015. “On Justice Kennedy’s Tenuous Grasp of Human Dignity.” Crisis Magazine. Cited: http://www.crisismagazine.com/2015/on-justice-kennedys-tenuousgrasp-of-human-dignity 
Esolen, Anthony. 2012. "Progressive Inhumanity, Part One: the State Against Humanity." Crisis Magazine. Cited:

https://www.catholicculture.org/culture/library/view.cfm?recnum=9890

Estes, Richard. 2010. "Toward Sustainable Development: From Theory to Praxis." Transnational Social Work Practice, 76.

Evans, Alex, and Steven, David. 2012. Sustainable Development Goals: A Useful Outcome From Rio + 20? Center on International Cooperation. New York, NY.

Feder, Gershon and David Feeny. 1991. "Land Tenure and Property Rights: Theory and Implications for Development Policy." The World Bank Economic Review 5, no. 1

Ferrara, Christopher. 2010. The Church and The Libertarian. Remnant Press. Minneapolis, MN.

Ferrara, Christopher. 2012. Liberty, the God that Failed: Policing the Sacred and Constructing the Myths of the Secular State, from Locke to Obama. Angelico Press. Brooklyn, NY.

Fichtner, W., Graehl, S., and Rentz, O. 2002. "International Cooperation to Support Climate Change Mitigation and Sustainable Development." International Journal of Environment and Pollution, 18(1), 33-55. 
Fisher, David. 2013. Roman Catholic Saints and Early Victorian Literature:

Conservatism, Liberalism, and the Emergence of Secular Culture. Ashgate Publishing, Ltd. Farnham, UK.

Fisher, Dana, \& Green, Jessica. 2004. "Understanding Disenfranchisement: Civil Society and Developing Countries' Influence and Participation in Global Governance for Sustainable Development." Global Environmental Politics, 4(3), 65-84.

Floyd, Alex. 2015. "A Communion of Dictators Binds Fascism and the Catholic Church." Vineyard Gazette. Cited: https://vineyardgazette.com/news/2015/07/30/communiondictators-binds-fascism-and-catholic-church

Follesdal, Andreas. 2000. "Subsidiarity and Democratic Deliberation." Democracy in the European Union: Integration through Deliberation, 85-110. Routledge. Oxon, UK.

Fowler, Alan. 2013. The Virtuous Spiral: A Guide to Sustainability for NGOs in International Development. Routledge. Oxon, UK.

Francis 2019. Address of His Holiness Pope Francis to Participants in the Plenary Session of the Pontifical Academy of Social Sciences. Cited: http://www.vatican.va/content/francesco/en/speeches/2019/may/documents/papafrancesco_20190502_plenaria-scienze-sociali.html 
Francis. 2015. Laudato Si: On Care for Our Common Home. Our Sunday Visitor. Indianapolis, Indiana.

Francis. 2014. Address of Pope Francis to the European Parliament. Cited: http://www.vatican.va/content/francesco/en/speeches/2014/november/documents/pap a-francesco_20141125_strasburgo-parlamento-europeo.html

Francis. 2014. World Day of Peace Message. Cited: http://www.vatican.va/content/francesco/en/messages/peace/documents/papafrancesco_20131208_messaggio-xlvii-giornata-mondiale-pace-2014.html

Francis. 2020. Querida Amazonia: The Beloved Amazon. Our Sunday Visitor. Indianapolis, Indiana.

Franzelin, Johannes. 1875. Ioannis Bapt. Franzelin tractatus de divina traditione et scriptura. Nabu Press. Charleston, SC.

Frederickson, H. George. 2005. "Whatever Happened to Public Administration? Governance, Governance Everywhere." The Oxford Handbook of Public Management, 282-304.

French, William. 2008. "Natural Law and Ecological Responsibility: Drawing on the Thomistic Tradition." U. St. Thomas LJ, 5, 12. 
Friedman, Elizabeth, Hochstetler Katherine, \& Clark, Ann. 2012. "Sovereignty, Democracy, and Global Civil Society." State-society relations at UN world conferences. SUNY Press. Albany, NY.

Frumkin, Peter, and Andre-Clark, Anne. 2000. "When Missions, Markets, and Politics Collide: Values and Strategy in the Nonprofit Human Services." Nonprofit and voluntary sector quarterly, 29 (1), 141-163

Glasmeier, Amy, and Farrigan, Tracey. 2003. "Poverty, Sustainability, and the Culture of Despair: Can Sustainable Development Strategies Support Poverty Alleviation in America's Most Environmentally Challenged Communities?" The Annals of the American Academy of Political and Social Science, 590(1), 131-149.

Glatz, Carol. 2019. "Pope Francis Promotes Integral Ecology to Combat 'Culture of Waste'”. America Magazine. Cited: https://www.americamagazine.org/faith/2019/09/20/pope-francis-promotes-integralecology-combat-culture-waste

Goodhart, Michael. 2016. Human Rights: Politics and Practice. Oxford university press. Oxford, UK.

Grasse, Alexis. 2016. "The Impact of Anthropocentrism on Christian Environmentalism." Dialogue \& Nexus, 3 (1), 18. 
Gray, Kevin and Gills, Barry. 2016. "South-South Cooperation and the Rise of the Global South." Third World Quarterly, 37(4), 557-574.

Guha, Ramachandra. 2000. Environmentalism: A Global History. Longman. New York, NY.

Geddes, Patrick (1957) Cited in: Mairet, Philip. Pioneer of Sociology: the Life and Letters of Patrick Geddes. Lund Humphries. London, UK.

Giddens, Anthony (1996). Para Alem da Esquerda e da Direita o Futuro da Politica Radical. Unesp. São Paulo, Brazil.

Goode, Keith. 2020. “Despite Ample Global Supplies, Concerns About "Food Nationalism," and Supply Chain Restrictions Amid COVID-19 Outbreak." Farm Policy News. Cited: https://farmpolicynews.illinois.edu/2020/03/despite-ampleglobal-supplies-concerns-about-food-nationalism-and-supply-chain-restrictions-amidcovid-19-outbreak/

Gianna Physicians Guild. 2019. About. Cited from http://www.stgiannaphysicians.org/

Grey, William. 1993. Anthropocentrism and Deep ecology. Australasian Journal of Philosophy, 71(4), 463-475. 
Grossman, Margaret. 200). Agriculture and the Polluter Pays Principle: an Introduction. Oklahoma Law Review., 59, 1.

Gu, Man-Li and Bomhoff, Edward. 2012. Religion and Support for Democracy: A Comparative Study for Catholic and Muslim Countries. Politics and Religion, 5(2), 280-316.

Hahn, Scott and Scott, D. (Eds.). 2007. Letter and Spirit: The Hermeneutic of Continuity Christ, Kingdom and Creation (Vol. 3). Emmaus Road Publishing. Steubenville, OH.

Hailwood, Simon. 2015. Alienation and Nature in Environmental Philosophy. Cambridge University Press. Cambridge, UK.

Haines, Gerald K. 1999. "The Pike Committee Investigations and the CIA.” Central Intelligence Agency. Washington DC Center for the Study of Intelligence. Washington DC.

Hall, Robert. 2012. Plato and the Individual. Springer. New York, NY.

Halligan, Patrick. 1989. "The Environmental Policy of St. Thomas Aquinas.” Environmental Law Vol. 19, No. 4 (Summer 1989), pp. 767-806

Hannigan, Jessica. 1995. Environmental sociology: A social constructionist perspective. 
Routledge Press. London, UK.

Haufler, Virginia. 2013. A Public Role for the Private Sector: Industry Self-Regulation in a Global Economy. Carnegie Endowment. Washington, DC.

Hefele, CJ. 2014. A History of the Christian Councils: From the Original Documents, Volume 2. Veritatis Splendor Publishing. Indianapolis, Indiana.

Heltberg, Rasmus 2002. "Property Rights and Natural Resource Management in Developing Countries." Journal of Economic Surveys, 16(2).

Hens, L., and Nath, B. 2003. “The Johannesburg Conference.” Environment, Development and Sustainability, 5(1-2), 7-39.

Hichborn, Michael. 2017. "Follow the Money Trail." California Catholic Daily. Cited: https://cal-catholic.com/follow-the-money-trail/

Hiwaki, Kensai. 2017. “A Balance Paradigm for Post-Plutocracy: Toward Sustainable Development With Integral Harmony.” Systems, 5(1), 16.

Holden, Erling, Linnerud, Kristin and Banister, David. 2014. "Sustainable Development: Our Common Future Revisited." Global Environmental Change, 26, 130-139. 
Hood, Christopher. 1995. The "New Public Management" in the 1980s: Variations on a Theme.” Accounting, Organizations, and Society, 20(2-3), 93-109.

Horn, Trent. 2017. The Case for Catholicism: Answers to Classic and Contemporary Protestant Objections. Ignatius Press. San Francisco, CA.

Hui, Loi. 2008. "Combining Faith and CSR: a Paradigm of Corporate Sustainability." International Journal of Social Economics, 35(6), 449-465.

Huppes, Gjalt and Ishikawa, Masanobu. 2009. "Eco-Efficiency Guiding Micro-Level Actions Towards Sustainability: Ten Basic Steps For Analysis.” Ecological Economics, 68(6), 1687-1700.

IFFD (2020). “The Crucial Role of Families.” United Nations. Cited: https://www.un.org/ecosoc/sites/www.un.org.ecosoc/files/files/en/integration/2017/IF $\underline{\text { FD.pdf }}$

Ignatius, St.. 1993. The Companion to the Catechism of the Catholic Church: A Compendium of Texts Referred to in the Catechism of the Catholic Church. Ignatius Press. San Francisco, CA.

Ihssen, Brenda. 2008. "Basil and Gregory's Sermons on Usury: Credit Where Credit is Due.” Journal of Early Christian Studies, 16(3), 403-430. 
Ivereigh, Austen. 2014. The Great Reformer: Francis and the Making of a Radical Pope. Henry Holt and Company. New York, NY.

Ives, Christopher and Kidwell, Jeremy. 2019. "Religion and Social Values for Sustainability.” Sustainability Science, 14(5), 1355-1362.

Jackson, Tim. (Ed.). 2006. The Earthscan Reader in Sustainable Consumption. Earthscan. London, UK.

Jacob, Merle. 1994. "Sustainable Development and Deep Ecology: an Analysis of Competing Traditions." Environmental Management, 18(4), 477.

Jacques, Peter. 2014. Sustainability: The Basics. Routledge. London, UK.

Jenkins, Willis. 2003. "Biodiversity and Salvation: Thomistic Roots for Environmental Ethics." The journal of religion, 83(3), 401-420.

Jenkins, William. 2013. The Future of Ethics: Sustainability, Social Justice, and Religious Creativity. Georgetown University Press. Washington, DC.

Joaquim, Henry. 2006. "The Organizational Dynamics of the Catholic Church in the Field of Social Care." British Journal of Social Work, 36, 351-372. 
John XXIII. 1961. "Mater et Magistra." Cited: http://www.vatican.va/content/johnxxiii/en/encyclicals/documents/hf_j-xxiii_enc_15051961_mater.html

John Paul II. 1984. "Address of John Paul II to the Members of the Special Committee of the United Nations Organization Against Apartheid.” Cited: http://www.vatican.va/content/john-paul-ii/en/speeches/1984/july/documents/hf_jpii_spe_19840707_onu-apartheid.html

John Paul II. 1995. Evangelium Vitae. Cited: http://www.vatican.va/content/john-paulii/en/encyclicals/documents/hf_jp-ii_enc_25031995 evangelium-vitae.html

John Paul II. 1999. The Church in America. USCCB Publishing. Indianapolis, IN.

Johnson, Ben. 2017. "Pope Francis on Employment, Subsidiarity, and the Soul of the EU.” Acton Institute Online. Cited: https://www.acton.org/publications/transatlantic/2017/03/28/pope-francisemployment-subsidiarity-and-soul-of-the-eu

Johnston, Todd. 1998. "The Role of International Equity in a Sustainable Future: the Continuing Problem of Third World Debt and Development." Environmental Law Journal, 6, 35 .

John Paul II. 1991. “Centesimus Annus - On the 100th anniversary of Pope Leo XIII's 
Rerum Novarum." Cited: http://www.vatican.va/content/john-paul-

ii/en/encyclicals/documents/hf_jp-ii_enc_01051991_centesimus-annus.html

Jones, E Michael. 2016. The Catholic Church and the Cultural Revolution. Fidelity Press. South Bend, IN.

Jones, E Michael. 2014. Barren Metal. Fidelity Press South Bend, IN.

Kates, R. W., \& Clark, W. C. 1999. “Our Common Journey.” National Academy. Washington DC.

Kauffman, Craig. 2019. "Why Rights of Nature Laws are Implemented in Some Cases and Not Others: the Controlled Comparison of Bolivia and Ecuador.” International Studies Association Annual Conference, March 29, 2019. Cited: http://files.harmonywithnatureun.org/uploads/upload861.pdf

KCCB (2014). "Statement by the Kenya Conference of Catholic Bishops on the Mass Tetanus Vaccination Campaign Carried Out in Kenya in March and October 2014." KCCB Website. Cited: https://www.kccb.or.ke/home/news-2/pressstatement-tetanus/

Kemmis, Daniel. 1990. Community and the Politics of Place. University of Oklahoma Press. Norman, OK. 
Kent, Peter. 2002. Lonely Cold War of Pope Pius XII: The Roman Catholic Church and the Division of Europe, 1943-1950. McGill-Queen's Press-MQUP. New York, NY.

Kerber, Guillermo. 2018. Latin American and Ecumenical Insights in Laudato Si'. The Ecumenical Review, 70(4), 627-636.

Keulartz, Jozef. 2012. "The Emergence of Enlightened Anthropocentrism in Ecological Restoration." Nature and Culture, 7(1), 48-71.

Kiely, Ray. 2016. The Rise and Fall of Emerging Powers: Globalisation, US power and the Global North-South Divide. Springer. New York, NY.

King, LA . 2014. Federalism and Subsidiarity. SUNY. New York, NY.

Kingdon, John. 1984. Agendas, Alternatives and Public Policies. Little. Brown \& Co. Boston, MA.

Kotler, Philip. 2019. “The Rise of Anti-Consumerism.” The Sarasota Institute. Cited: https://sarasotainstitute.global/the-rise-of-anti-consumerism/

Kotze, Louis and French, Duncan. 2018. "The Anthropocentric Ontology of International Environmental Law and the Sustainable Development Goals: Towards an Ecocentric Rule of Law in the Anthropocene." Global Journal of Comparative Law, 7(1), 5-36. 
Kotzé, Louis. 2014. "Human Rights and the Environment in the Anthropocene." The Anthropocene Review, 1(3), 252-275.

Kriebel, David, Tickner Joel, Epstein Paul. 2001. "The Precautionary Principle in Environmental Science.” Environmental Health Perspectives, 109(9), 871-876.

Kopnina, Helen. 2014. "Revisiting Education for Sustainable Development (ESD): Examining Anthropocentric Bias Through the Transition of Environmental Education to ESD." Sustainable Development, 22(2), 73-83.

Lahsen, Myanna and Domingues, Jose. 2015. “Pope Francis's Environmental Encyclical in Latin America: Mutual Influences." Environment: Science and Policy for Sustainable Development, 57(6), 20-23.

Law, John. 2013. "How Can We Define Federalism? "Perspectives on Federalism, 5(3), E105-6.

Lawler, Philip. 2018. Lost Shepherd: How Pope Francis is Misleading his Flock. Gateway Editions. Washington, DC.

Le'le', Sharachchandra. 1991. "Sustainable Development: a Critical Review." World Development, 19(6), pp. 607-621. 
Lee, Robert. 1994. Broken Trust, Broken Land: Freeing Ourselves From the War Over the Environment. Bookpartners. North Manchester, IN.

Lee, Eliza. 1995. "Political Science, Public Administration, and the Rise of the American Administrative State." Public Administration Review, 55(6), 538-546.

Lee, Terence and McGahan, Kevin. 2015. "Norm Subsidiarity and Institutional Cooperation: Explaining the Straits of Malacca Anti-Piracy Regime.” The Pacific Review, 28(4), 529-552.

Leo XIII. 1891. "Rerum Novarum.” Cited: http://www.vatican.va/content/leoxiii/en/encyclicals/documents/hf_l-xiii_enc_15051891_rerum-novarum.html

Leo XIII. 1881. "Diuturnum.” Cited: http://w2.vatican.va/content/leoxiii/en/encyclicals/documents/hf_l-xiii_enc_29061881_diuturnum.html

Leo XIII. 1884. "Humanum Genus.” Cited: http://www.vatican.va/content/leoxiii/en/encyclicals/documents/hf_l-xiii_enc_18840420_humanum-genus.html

Leo XIII. 1878. “Quod Apostolici Muneris.” Cited: http://www.vatican.va/content/leoxiii/en/encyclicals/documents/hf_l-xiii_enc_28121878_quod-apostolici-muneris.html

Leo XIII. 1901. "Graves de Communi Re.” Cited: http://www.vatican.va/content/leo- 
xiii/en/encyclicals/documents/hf_1-xiii_enc_18011901_graves-de-communi-re.html

Leo XIII. 1885. “Immortale Dei.” Cited: http://www.vatican.va/content/leoxiii/en/encyclicals/documents/hf_1-xiii_enc_01111885_immortale-dei.html

Leopold, Aldo. 1992. The River of the Mother of God: and Other Essays by Aldo Leopold. Univ of Wisconsin Press. Madison, WI.

Levitt, Barbara and March, James. 1988. “Organizational Learning.” Annual Review of Sociology, 14(1), 319-338.

Littig, Beate and Griessler, Erich. 2005. "Social Sustainability: a Catchword Between Political Pragmatism and Social Theory." International Journal of Sustainable Development, 8(1-2), 65-79.

Long, Rodrick and Machan, Tibor (Eds.). 2012. Anarchism/Minarchism: is a Government Part of a Free Country? Ashgate Publishing, Ltd. Farnham, UK.

Lynne Lee, W. (2005). The aesthetic appreciation of nature, scientific objectivity, and the standpoint of the subjugated: anthropocentrism reimagined. Ethics Place and Environment, 8(2), 235-250.

MacIntyre, Alasdair. 2007. After Virtue: A Study in Moral Theory. Duckworth. London, 
UK.

Magill, Gerard. 2017. “The Urgency of Climate Change." The Urgency of Climate Change: Pivotal Perspectives, 450. Cambridge University. Cambridge, UK.

Maltin, Elyse. 2019. "What Successful Public-Private Partnerships Do.” Harvard Business Review. Cited: https://hbr.org/2019/01/what-successful-public-privatepartnerships-do

Marsh, George. 2001. So Great a Vision: the Conservation Writings of George Perkins Marsh. UPNE. Lebanon, NH.

McGavin, Paul A. 2016. "What's wrong with Laudato Si?” cited http://chiesa.espresso.repubblica.it/articolo/1351224.html

Makoba, J. Wagona. 2002. "Nongovernmental Organizations (NGOs) and Third World Development: An Alternative Approach to Development." Journal of Third World Studies, 19(1), 53-63.

Mandle, Jay. 1980. "Marxist Analyses and Capitalist Development in the Third World." Theory and Society, 9(6), 865-876.

Maritain, Jacques. 1951. The Rights of Man and Natural Law. Charles Scribner's Son. 
New York, NY.

Maritain, Jacques. 2012. Christianity and Democracy, the Rights of Man and Natural Law. Ignatius Press. San Francisco, CA.

Markowitz, Ezra. 2012. "Is Climate Change an Ethical Issue? Examining Young Adults' Beliefs About Climate and Morality." Climatic Change, 114(3-4), 479-495.

Martin, James 2015. “Ten Takeaways From Ladauto Si.” America Magazine Online. Cited: https://www.americamagazine.org/faith/2015/06/18/top-ten-takeaways$\underline{\text { laudato-si }}$

Martinez, Francisco. 2004. "Beyond Secular Reason”. Communio 31/4; 2.

Marx, Karl. 1844. "Human Requirements and Division of Labour Under the Rule of Private Property." Collected Works, 3, 306-321.

Massey, Doreen. 1991. “A Global Sense of Place.” Marxism Today. June 24-29.

Massey, Doreen. 1994. Space, Place, and Gender. University of Minnesota Press. Minneapolis, MN.

Mattson, David and Clark, Susan. 2011. "Human Dignity in Concept and Practice." 
Policy Sciences, 44(4), 303-319.

McCallum, Malcolm L. 2019. "Perspective: Global Country-by-Country Response of Public Interest in the Environment to the Papal Encyclical, Laudato Si." Biological conservation, 235, 209-225.

McGrath, Alister. 2008. Christianity's Dangerous Idea: The Protestant Revolution--a History from the Sixteenth Century to the Twenty-first. Harper Collins. New York, NY.

McKenzie, Stephen. 2004. "Social Sustainability: Towards Some Definitions.” University of South Australia. Magill, SA. Cited: https://www.unisa.edu.au/siteassets/episerver6-files/documents/eass/hri/working-papers/wp27.pdf

McNabb, Vincent. 1941. “Towards Nazareth.” The Cross and The Plough, 8 (1). 144

McNabb, Vincent. 2014. “The Catholic Land Movement.” The Distributist Review. Cited: $\underline{\text { https://distributistreview.com/archive/the-catholic-land-movement }}$

McNabb, Vincent. 1942. Old Principles and the New Order. Sheed and Ward. London, UK.

Michon, Xavier. and Michano, Jaffer. 2020. "The Future of Development is Local." 
Foreign Policy. Cited: https://foreignpolicy.com/2020/01/22/sustainabledevelopment-goals-sdgs-think-local-cities/

Mignone, Emilio F. 1988. Witness to the Truth: The Complicity of Church and Dictatorship in Argentina, 1976-1983. Orbis Books. New York, NY.

Moffitt, Benjamin. 2016. The Global Rise of Populism: Performance, Political Style, and Representation. Stanford University Press. Stanford, CA.

Moldan, Bedric, Janoušková, Svatana and Hák, Tomas. 2012. "How to Understand and Measure Environmental Sustainability: Indicators and Targets." Ecological Indicators, 17, 4-13.

Molina, Fernando, and Miguez, Antonio. 2008. "The Origins of Mondragon: Catholic Co-Operativism and Social Movement in a Basque Valley (1941-59).” Social History, 33(3), 284-298.

Monaci, Massimillano. 2020. "Embedding Humanizing Cultures in Organizations Through 'Institutional' Leadership: The Role of HRM.” Humanistic Management Journal, 1-25.

Moore, Virginia. 1942. "Human Nature According to Saint Thomas Aquinas." Loyola University. Cited: 
https://ecommons.luc.edu/cgi/viewcontent.cgi?article=1664\&context=luc theses

Morgan, Douglas, and Cook, Brian. 2015. New Public Governance: A Regime-Centered Perspective. Routledge. New York, NY.

Mounk, Yascha. 2019. Evo Morales Finally Went Too Far for Bolivia. The Atlantic. Cited:

https://www.theatlantic.com/ideas/archive/2019/11/evo-morales-finally-went-too-farbolivia/601741/

Moynihan Donald, and Pandey, Sanjay. 2008. "The Ties That Bind: Social Networks, Person-Organization Value Fit, and Turnover Intention. Journal of public administration research and theory, 18(2), 205-227.

Muir, John. 1917. The Writings of John Muir: The story of my boyhood and youth (Vol. 1). Houghton Mifflin. Boston, MA.

Murphy David, and Bendell, Jem. 199). In the Company of Partners: Business, Environmental Groups and Sustainable Development Post-Rio. Policy Press. Bristol, UK.

Naess, Arne. 1973. "The Shallow and the Deep, Long - Range Ecology Movement. A 
Summary." Inquiry, 16(1-4), 95-100.

Ndemo, Elijah. 2006. "Assessing Sustainability of Faith-Based Enterprises in Kenya." International journal of social economics. ISSN: 0306-8293. https://www.emerald.com/insight/content/doi/10.1108/03068290610660706/full/html

Neel, James. 1942. "A Study of a Case of High Mutation Rate in Drosophila Melanogaster.” Genetics, 27(5)., 519.

Nelson, Robert H. 1999. “The Religion of Forestry: Scientific Management.” Journal of Forestry, 97(11), 4-8.

Nielsen, Laura and Albiston Catherine. 2005. "The Organization of Public Interest Practice: 1975-2004.” NCL Review, 84, 1591.

Neuhaus, Richard J. 2012. Doing Well and Doing Good: the Challenge to the Christian Capitalist. Image. Colorado Springs, CO.

Njoku, Uzochukwu J. 2007." Discourse on the Foundations of Solidarity in the Social Encyclicals of John Paul II.” Ethical Perspectives, 14(1):79-97.

Njue, John. 2015. "Statement by The Kenyan Conference of Catholic Bishops." Cited: https://www.kccb.or.ke/home/news-2/pressstatement-tetanus/ 
Nunes, Michael. 2004. "Serviço Social e regulação social: agência do assistente social." Porto: Estratégias Criativas. Arcozelo Vng, Portugal.

Oakeshott, Robert. 1975. "Mondragon: Spain's oasis of democracy.” Self-Management: The Economic Liberation of Man. Penguin Books. Baltimore, MD.

OECD 2019. "Financing for Sustainable Development." Cited: http://www.oecd.org/dac/financing-sustainable-development/

O'Grady, Siobhan. 2018. "Leaders Pledged to Greatly Reduce Poverty by 2030." Washington Post. Cited: https://www.washingtonpost.com/world/2018/09/25/leaderspledged-greatly-reduce-poverty-by-some-places-deprivation-may-only-get-worse/

Oller, John. 2017. HCG Found in WHO Tetanus Vaccine in Kenya Raises Concern in the Developing World. Open Access Library Journal, 4(10), 1.

Osborne, Thomas. 2008. "MacIntyre, Thomism and the Contemporary Common Good." Analyse \& Kritik, 30(1), 75-90.

Ostrom, Elinor. 2007. “Sustainable Social-Ecological Systems: an Impossibility? Presented at the 2007 Annual Meetings of the American Association for the Advancement of Science, "Science and Technology for Sustainable WellBeing.” Cited: 
http://citeseerx.ist.psu.edu/viewdoc/download?doi=10.1.1.539.5428\&rep=rep1\&type $=\mathrm{pdf}$

Ostrom, Elinor., and Hess Charlotte. 2000. "Private and Common Property Rights." Encyclopedia of law and economics. Edward Elgar Publishing Limited. Cheltenham, UK.

Paquet, P. C., and Darimont C. T. 2010. "Wildlife Conservation and Animal Welfare: Two Sides of the Same Coin.” Animal Welfare, 19(2), 177-190.

Parikh, Tapan. 2009. "Engineering Rural Development." Communications of the ACM, $52(1), 54-63$.

Paul III 1537. "Sublimus Dei.” Cited:

https://www.papalencyclicals.net/paul03/p3subli.htm

Paul VI. 1965. "Dignitatis Humanae." Cited: http://www.vatican.va/archive/hist_councils/ii_vatican_council/documents/vatii_decl_19651207_dignitatis-humanae_en.html

Paul VI. 1967. "Populorum Progressio." Cited: http://w2.vatican.va/content/paulvi/en/encyclicals/documents/hf_p-vi_enc_26031967_populorum.html 
Paul VI. 1971. "Octagesima Advieniens.” Cited: http://www.vatican.va/content/paulvi/en/apost_letters/documents/hf_p-vi_apl_19710514_octogesima-adveniens.html

Paul VI. 1972. "Message of His Holiness Paul VI to Mr. Maurice F. Strong, SecretaryGeneral of the Conference on the Environment." Cited: https://w2.vatican.va/content/paul-vi/en/messages/pont-messages/documents/hf_pvi_mess_19720605_conferenza-ambiente.html

Pearce, David and Turner, Terry. 1990. "Economics of Natural Resources and the Environment." Hemel Hempstead: Harvester Wheatsheaf. Hertfordshire, England.

Perry, James L. and Wise, L. R. 1990. “The Motivational Bases of Public Service.” Public Administration review, 50 367-373.

Philpott, Daniel. 2000. “The Religious Roots of Modern International Relations.” World Politics, 52(2), 206-245.

Pierce, Joseph, Martin Deborah, and Murphy James T. 2011. "Relational Place - Making: the Networked Politics of Place." Transactions of the Institute of British Geographers, 36(1), 54-70.

Pierre, F., Fadeeva, Z., Ogbuigwe, A., Jackson, T. D., Mattar, H., and Pedrina, L. 2011. "Visions For Change: Recommendations For Effective Policies on Sustainable 
Lifestyles." Paris: United Nations Environment Programme. Cited:

http://www.unep.fr/scp/publications/details.asp?id=DTI/1321/PA.

Peterson, John. 1995. "Distributism and Labor Unions.” The Distributist. Cited:

http://americanchestertonsociety.blogspot.com/2006/10/unions-guilds-distributism-

chesterton.html

Pinchot, Gifford. 1910. The Fight for Conservation. Harcourt Brace. Garden City, NY.

Pinchot, Gifford. 1947. Breaking New Ground. Island Press .Washington D.C.

Pius X. 190). “In Il Fermo Proposito.” Cited: https://www.catholicaction.org/about_us

Pius IX. 1849. "Nostis et Nobiscum.” Cited:

https://www.papalencyclicals.net/pius09/p9nostis.htm

Pius X. 1910. “Apostolic Letter Notre Charge Apostolique.” Cited:

https://www.papalencyclicals.net/pius10/p10notre.htm

Pius XI. 1925. “Quas Primas.” Cited: http://w2. vatican.

va/content/piusxi/en/encyclicals/documents/hf_p-xi_enc_11121925_quas-primas. html (востанне відвідано 07. 03. 2018). 
Pius XI 1931. "Non Abbiamo Bisogno.” Cited: http://www.vatican.va/content/piusxi/en/encyclicals/documents/hf_p-xi_enc_29061931_non-abbiamo-bisogno.html

Pius XI. 1931. “Quadragesimo Anno.” Cited: http://www.vatican.va/content/piusxi/en/encyclicals/documents/hf_p-xi_enc_19310515_quadragesimo-anno.html

Pius XII. (1939. “Summi Pontificatus.” Cited: http://www.vatican.va/content/piusxii/en/encyclicals/documents/hf_p-xii_enc_20101939_summi-pontificatus.html

Plumwood, Val. 2002. Environmental Culture: The Ecological Crisis of Reason. Psychology Press. London, UK.

Princen, Thomas. 1992. "Mediation By a Transnational Organization: the Case of the Vatican." Mediation in International Relations. Palgrave-McMillan, London, UK.

Raco, Mike. 2005. "Sustainable Development, Rolledout Neoliberalism and Sustainable Communities." Antipode, 37(2), 324-347.

Purvis, Ben, Mao Yen, and Robinson David. 2019. "Three Pillars of Sustainability: in Search of Conceptual Origins.” Sustainability Science, 14(3), 681-695.

Putnam, Robert D. 1994. Making Democracy Work: Civic Traditions in Modern Italy. Princeton university press. Princeton, NJ. 
Ray, Steve. 1999. Upon This Rock. Ignatius Press. San Francisco, CA.

Richardson, Dick. 1997. "The Politics of Sustainable Development.” The Politics of Sustainable Development. Routledge. Abington, UK.

Ripperger, Chad. 2014. Magisterial Authority. CreateSpace Publishing. Charleston, South Carolina.

Rittel, Horst W., and Webber, Melvin. 1973. "Dilemmas in a General Theory of Planning." Policy Sciences, 4(2), 155-169.

Rittel, Horst W., and Webber, Melvin. 1974. "Wicked Problems.” Man-made Futures, 26(1), 272-280.

Roberts, J. Timmons. 2011. "Multipolarity and the New World (dis) Order: US Hegemonic Decline and the Fragmentation of the Global Climate Regime.” Global Environmental Change, 21(3), 776-784.

Robinson, John. 2004. "Squaring the Circle? Some Thoughts on the Idea of Sustainable Development." Ecological economics, 48(4), 369-384.

Rocca, Xavier. 2012. "Is Capitalism Catholic? A Priest Defends Free-Market Economics.” Catholic News Service. Cited: 
https://www.ncronline.org/news/people/capitalism-catholic-priest-defends-free-

$\underline{\text { market-economics }}$

Russell, Nathan J. 2006. “An Introduction to the Overton Window of Political Possibilities." Students for a Free Economy Clarkson Colloquium. Cited: http://www.theihs.org/academic/PDFs/SFE\%20Clarkson\%20Colloquium\%20Reading s.pdf

Sabatier, Paul, and Mazmanian, Daniel. 1980. "The Implementation of Public Policy: A Framework of Analysis.” Policy Studies Journal, 8(4), 538-560.

Sabel, C. F. (1989). The reemergence of regional economies. Reversing Industrial Decline? Industrialized Structure and Policy in Britain and Her Competitors. Oxford University Press. Oxford, UK.

Scheberle, Denise. 1997. Federalism and Environmental Policy. Georgetown University Press. Washington, DC.

Schindler, David 2013. "Freedom, Truth, and Human Dignity: an Interpretation of Dignitatus Humane on the Right to Religious Liberty." Communio. Washington, DC.

Scruton, Robert. 2016. "Beauty and Desecration." Quaestiones Disputatae, 6(2), 150163. 
Scruton, Robert. 2009. "Working Towards Art." The British Journal of Aesthetics, 49(4), 317-325.

Scruton, Robert. 2012. “Green Shoots.” RSA Journal, 158(5549), 42-45.

Seckinelgin, Hakan. 2005. The Environment and International Politics: International Fisheries, Heidegger and Social Method. Routledge. Abington, UK.

Second Vatican Council. 1992. Documents of Vatican council II. Cited: http://www.vatican.va/jubilee 2000/magazine/documents/ju mag 01051997 p$\underline{21 \text { en.html }}$

Selznick, Philip. 2011. Leadership in Administration: A Sociological Interpretation. Quid Pro Books. New Orleans, LA.

Sheen, Fulton. 1929. "Philosophical Theology.” The New Scholasticism, 3(1), 80-83.

Sheen, Fulton. 1948. Communism and the conscience of the west. Bobbs-Merrill. Indianapolis, NY.

Sheen, Fulton. 1940. Freedom Under God. Bruce Publishing Company. New York, NY.

Sherr, Ian. 2020. 'Bill Gates Calls COVID-19 Vaccine Conspiracy Theories 'Stupid,' But 
Many Believe Them." CNet. Cited: https://www.cnet.com/news/bill-gates-callswrongful-covid-19-vaccine-conspiracy-theories-stupid-but-many-people-believe$\underline{\text { them/ }}$

Sitarz, D. 1993. Agenda 21: The earth summit strategy to save our planet. US Department of Energy. Washington, DC.

Slade, Stephanie. 2019. "The New Theocrats are Neither Conservative Nor Christian." Reason Magazine. Cited: https://reason.com/2019/06/03/the-new-theocrats-areneither-conservative-nor-christian/

Smith, Amanda. 2006. Production and Consumption of Wildlife Icons: Dolphin Tourism at Monkey Mia, Western. CABI Books. Oxfordshire, England.

Smith, Stansfield. 2018. "Eleven Years of the 'Process of Change' in Evo Morales' Bolivia." Council on Hemispheric Affairs. Council on Hemispheric Affairs. Washington, DC. Cited: $\underline{\text { https://www.coha.org/wp- }}$ content/uploads/2018/01/EvoMorales_Smith.pdf

Smythe, Kathleen R. 2014. "Rethinking Humanity in the Anthropocene: the Long View of Humans and Nature." Sustainability: The Journal of Record, 7(3), 146-153.

Sparks, Russell. 2016. "What We Can Learn From the Guilds." Distributist Review. 
Cited: https://distributistreview.com/can-learn-guilds/

Spencer, Andrew. 2013. "Five Insights About Private Property From Aquinas." Institute for Faith, Work, \& Economics. Cited: https://tifwe.org/five-insights-about-privateproperty-from-aquinas/

Soloviy, Vitaliy. 2019. "Study: Individualistic Cultures are Worse for the Environment." Sustainability Times. Cited: https://www.sustainability-times.com/greenconsumerism/study-individualistic-cultures-are-worse-for-the-environment/

St. Kateri Center 2020. "Habitat Restoration.” Cited: https://www.kateri.org/saint-katerihabitat-2/

Steele, Lindsay. 2018. "Iowa City Catholic Worker Establishes Land Trust.” The Catholic Messenger. Cited: http://www.catholicmessenger.net/2018/08/iowa-city-catholicworker-establishes-community-land-trust/

Stetson, Brad. 1998. Human dignity and contemporary liberalism. Greenwood Publishing Group. Westport, CT.

Sunstein, Cass R. 2003. “Beyond the Precautionary Principle.” University of Pennsylvania Law Review, 151(3), 1003-1058. 
Taylor, Bron. 2001. "Earth and Nature-Based Spirituality (Part I): From Deep Ecology to Radical Environmentalism.” Religion, 31(2), 175-193.

Taylor, Paul W. 2011. Respect for Nature: A Theory of Environmental Ethics. Princeton University Press. Princeton, NJ.

Thoresen, Victoria. 2015. Responsible Living: Concepts, Education and Future Perspectives. Springer. New York, NY.

Tilson, D. J. 2014. “An Alternative View of Social Responsibility: The Ancient and Global Footprint of Caritas and Public Relations." In Pathways to Public Relations. Routledge. London, UK.

Tummers, Lars. 2017. "Bureaucracy and Policy Alienation." Global Encyclopedia of Public Administration, Public Policy, and Governance (3rd edition). Springer. New York, NY.

UN. 2019. "Stand for Peace and Harmony, Says Guterres, Following Meeting with Pope Francis.” UN News. Cited: https://news.un.org/en/story/2019/12/1054091

United Nations 1993."Agenda 21: Programme for Action for Sustainable Development." Cited: http://petenmizu19.gotdns.ch/676.htm 
Unbound 2020. “Mission Statement.” Cited:

http://gkccf.guidestar.org/NonprofitProfile.aspx? $\operatorname{OrgId=1266}$

USCCB. 2018. "Life and Dignity of the Human Person." Cited:

http://www.usccb.org/beliefs-and-teachings/what-we-believe/catholic-socialteaching/life-and-dignity-of-the-human-person.cfm

USCCB. 2018. "The Dignity of Work and the Rights of the Worker." Cited: http://www.usccb.org/beliefs-and-teachings/what-we-believe/catholic-socialteaching/the-dignity-of-work-and-the-rights-of-workers.cfm

USCCB. 2018. "To Be a Christian Steward: A Summary of the U.S. Bishops' Pastoral Letter on Stewardship." Cited: http://www.usccb.org/beliefs-and-teachings/what-webelieve/stewardship/index.cfm

Van den Berg, Agnes \& Staats, Henk. 2007. "Preference For Nature in Urbanized Societies: Stress, Restoration, and the Pursuit of Sustainability." Journal of social issues, 63(1), 79-96.

Van Tine, Robin. 2017. "Reflections, Analysis, and Significance For Human Ecology of Pope Francis's Encyclical letter Laudato Si' On Care for Our Common Home." Human Ecology Review, 23(1), 141-178. 
Vatican News. 2018. "Pope Urges Children of Catholic Action to Be "Channels" of Goodness." Cited: https://www.vaticannews.va/en/pope/news/2018-12/pope-franciscatholic-action-children.html

Vélez, Juan. 2009. "Freedom of Conscience in Ethical Decision Making." The Linacre Quarterly, 76(2), 120-132.

Vincent, Andrew. 2009. Modern Political Ideologies. John Wiley \& Sons. Hoboken, NJ.

Von Humboldt, Alexander. 1889. Personal Narrative of Travels to the Equinoctial Regions of America, During the Year 1799-1804. G. Bell. London, UK.

Wapner, Paul. 2003. “World Summit on Sustainable Development: Toward a Post-Jo'burg Environmentalism." Global Environmental Politics, 3(1), 1-10.

Warren, Charlotte, and Bellows, Ben. 2011. "Evaluation of the Impact of the Voucher and Accreditation Approach on Improving Reproductive Health Behaviors and Status in Kenya." BMC public health, 11(1), 177.

Weber, Eugene 1990. The Western Tradition: A Book of Readings from the Ancient World to Louis XIV. Heath. Lexington, MA.

Wells, Carol. 2017. "Pope Meets With Youth of Catholic Action.” Vatican News. Cited: 
https://www.vaticannews.va/en/pope/news/2017-12/pope-meets-with-youth-of-

catholic-action.html

Wemhoff, David. 2015. “John Courtney Murray, Time/Life, and the American Proposition.” Fidelity Press. South Bend, Indiana.

White, Lynne. 1967. "The Historical Roots of Our Ecologic Crisis.” Science, 155(3767), 1203-1207.

Wilson, James Q. 1975. “The Rise of the Bureaucratic State.” The Public Interest, 41(3), $77-103$.

Worth, Owen. 2015. Rethinking Hegemony. Macmillan International Higher Education. New York, NY.

Wright, Bradley E., \& Pandey, Sanjay K. 2008. "Public Service Motivation and the Assumption of Person-Organization Fit: Testing the Mediating Effect of Value Congruence." Administration \& Society, 40(5), 502-521.

Young, Ernest A. 2002. "Protecting Member State Autonomy in the European Union: Some Cautionary Tales from American Federalism.” NYUL rev., 77, 1612.

Zmirak, John. 2017. "What Catholic Social Teaching Isn't.” The Stream. Cited: 
https://stream.org/pope-is-not-an-oracle-and-the-church-is-not-the-party/

Zweibach, Eric. 201). "Winco's Employee-Owners Speak Out. Supermarket News.” Cited: https://www.supermarketnews.com/retail-amp-financial/winco-s-employeeowners-speak-out

Zwick, Mar, \& Zwick, Louise. 2005. The Catholic Worker Movement: Intellectual and Spiritual Origins. Paulist Press. New York, NY. 